This document contains new concepts or the author(s) interpretation of new calculations and/or measurements; accordingly, EG\&G Idaho, Inc. is required by the United States Government to include the following disclaimer:

\section{DISCLAIMER}

This report was prepared as an account of work sponsored by an agency of the United States Government. Neither the United States Government nor any agency thereof, nor any of their employees, makes any warranty, express or implied, or assumes any legal liability or responsibility for the accuracy, completeness, or usefulness of any information, apparatus, product or process disclosed, or represents that its use would not infringe privately owned rights. References herein to any specific commercial product, process, or service by trade name, trademark, manufacturer, or otherwise, does not necessarily constitute or imply its endorsement, recommendation, or favoring by the United States Government or any agency thereof. The views and opinions of authors expressed herein do not necessarily state or reflect those of the United States Government or any agency thereof. 


\section{DISCLAIMER}

This report was prepared as an account of work sponsored by an agency of the United States Government. Neither the United States Government nor any agency Thereof, nor any of their employees, makes any warranty, express or implied, or assumes any legal liability or responsibility for the accuracy, completeness, or usefulness of any information, apparatus, product, or process disclosed, or represents that its use would not infringe privately owned rights. Reference herein to any specific commercial product, process, or service by trade name, trademark, manufacturer, or otherwise does not necessarily constitute or imply its endorsement, recommendation, or favoring by the United States Government or any agency thereof. The views and opinions of authors expressed herein do not necessarily state or reflect those of the United States Government or any agency thereof. 


\section{DISCLAIMER}

Portions of this document may be illegible in electronic image products. Images are produced from the best available original document. 


\section{DISCLAIMER}

Portions of this document may be illegible in electronic image products. Images are produced from the best available original document. 


\title{
THE FEASIBILITY OF APPLYING GEOPRESSURED-GEOTHERMAL RESOURCES TO DIRECT USES
}

\author{
Ben C. Lunis \\ Jane Negus-de Wys \\ Mart in M. Plum \\ Paul J. Lienau \\ F. J. Spencer ${ }^{b}$ \\ George F. Nitschke
}

September 1991

a. Oregon Institute of Technology Geo-Heat Center

b. International Mangement Services

c. Consultant

Prepared for the

U.S. Department of Energy

Field Office, Idaho

Under DOE Contract No. DE-AC07-761D01570 


\section{ABSTRACT}

This study concludes that direct use technologies, especially desalinated water production, can contribute significantiy to the value added process and the overall economic viability in developing a geopressured resource. Although agriculture and aquaculture applications are marginal projects when they are the only use of a geopressured well, the small margin of profitability can contribute to improving the overall economics of the direct use development. The added complexity from a technical and management aspect may add to the overall risk and unpredictability of the project.

Six combinations of direct uses received economic evaluation that resulted in 15\% discounted payback periods ranging from 4 to over 10 years. These are listed in Table 4. Many other combinations are possible depending on the resource and market variables. Selection of appropriate technologies and sizes of applications will be established by the developer that engages in geopressured resource utilization.

Currently, many areas of the country where geopressured resources are located also have surplus electrical capacity and generation, thus power utilities have been selling power for less than 2 cents per kWH, well below a reasonable breakeven value for geopressured produced electricity. However, when the energy demand of the integrated geopressured facility is 1 arge enough to install power generation equipment, operating expenses can be reduced by not paying the 10 to 12 cents per KWH utility rate.

The study includes an analysis of a geothermal turbine unit installed with a desalination and an agriculture/aquaculture facility, taking advantage of the cascading energy values. Results suggest that this scenario becomes profitable only where the market price for electricity exceeds five cents per kWH. 


\section{ACKNOWLEDGMENT}

Work supported by the U.S. Department of Energy, Assistant Secretary for Conservation and Renewable Energy Office of Utility Technologies, Under DOE Contract No. DE-AC07-76ID01570. 


\section{CONTENTS}

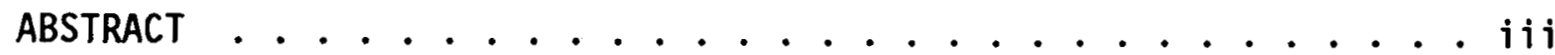

ACKNOWLEDGMENTS .................... . . . . .

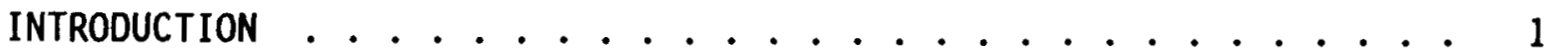

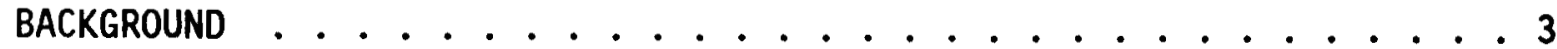

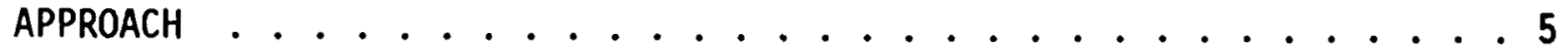

FINDINGS AND CONCLUSIONS ................. 7

HYDROTHERMAL-GEOTHERMAL DEVELOPMENTS ............. . .

THE GEOPRESSURED RESOURCE . . . . . . . . . . . . . 13

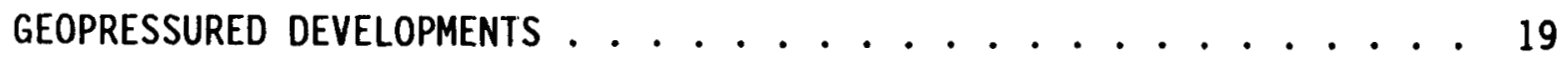

Power Generation ............... 19

Potential Industrial Applications ............ 19

Desalination .................. 20

Gas Use and Sales................... . . 26

Pollutant Removal ................. 26

Thermal Enhanced 0il Recovery ............... 27

Sulfur Frasching .............. 28

Petroleum and Natural Gas Pipelining ........... 29

Coal Desulfurization and Preparation ........... 30

Lumber and Concrete Products Kilning ............ 30

Paper and Cane Sugar Industries............... . 30

Chemical Processing............... 31

Chemicals in Geopressured Fluids ............. 31

Potential Agriculture and Aquaculture Applications ...... 35

Greenhousing ................ 35

Production Plot Warming and Frost Protection . . . . . . 36

Rearing of Fish, Crustaceans, Exotics, Turtles,

Processing and Alligators ................. 37

ECONOMIC CONSIDERATIONS ................. 4 . .

General ........................ 41

Economic Methodology and Assumptions ............ 42

Desalination Economics ............. . . 43

Agriculture/Aquaculture Economics ............ 45

Desalination/Agriculture/Aquaculture Economic Results . . . . 53

REFERENCES ..................... 57 
APPENDIX A--SEATTLE TIMES EDITORIAL "CALIFORNIA WON'T FACE WATERING

TRUTH, " MAY 27, 1990 . . . . . . . . . . . . . . . . A-1

APPENDIX B--HEATING REQUIREMENTS FOR THERMAL REFUGE AREAS

(K. RAFFERTY, OREGON INSTITUTE OF TECHNOLOGY GEO-HEAT . . . . . . B-1

APPENDIX C--INTEGRATED APPLICATIONSECONOMICANALYSES . . . . . . . . C-1

APPENDIX D--PRELIMINARY FEASIBILITY FOR GREENHOUSE/AQUACULTURE

FACILITY AT PLEASANT BAYOU, TEXAS. (P. J. LIENAU,

OREGON INSTITUTE OF TECHNOLOGY GEO-HEAT CENTER) . . . . . . . D-1

APPENDIX E--WATER WELL QUOTATION (R. DEMARCY, B\&J WATER WELL SERVICES) E-1

APPENDIX F--COMPARATIVE PERFORMANCE ANALYSIS: COMMERCIAL CUT-FLOWER

PRODUCTION ( $J$. WHITTIER, SOUTHWEST TECHNOLOGY DEVELOPMENT

INSTITUTE) SEATTLE TIMES EDITORIAL . . . . . . . . . . F-1

\section{FIGURES}

1. Potential geopressure applications and their temperature requirements......................... 6

2. Feasible desalination facility............. . 8

3. Feasible desalination/agriculture/aquaculture complex . . . . 8

4. Growth in hydrothermal-geothermal applications . . . . . . . 11

5. Location of geopressured-geothermal basins in the United States 16

6. Hydrothermal resources in the United States . . . . . . . 17

7. Potential geopressured integrated facility .......... 22

8. Extraction of bromine from seawater or selected brines . . . . 33

9. Salt brine derivatives................ 34

10. Process flow diagram for Phase 1 greenhouse/aquaculture complex 48

11. Aquaculture high density recirculation system . . . . . . . 49

12. Potential greenhouse/aquaculture complex . . . . . . . . . 50 


\section{TABLES}

1. Proposed freshwater supplies from geopressured fluids for California . . . . . . . . . . . . . . . . 25

2. Pleasant Bayou brine analysis ............... 33

3. Agriculture/aquaculture first phase cost estimate . . . . . 49

4. Discounted payback periods for various geopressured integrated facilities...................... 56 


\section{THE FEASIBILITY OF APPLYING GEOPRESSURED- GEOTHERMAL RESOURCES TO DIRECT USES}

\section{INTRODUCTION}

Natural gas and the high temperatures and pressures found in geopressured-geothermal (geopressured) resources create the opportunity for many new applications. The objectives of this feasibility study are to provide a brief overview of the various direct uses that are under consideration to utilize the relatively clean and environmentally benign energy that is available in the geopressured resource, to identify the areas of greatest industry interest, and to identify those applications that appear to have the greatest potential for utilization and impact. Information regarding the various direct uses was obtained from industry, academic, government, and other organizations through personal contact, publications, and documentation. Based on the information obtained, thermally enhanced oil recovery, supercritical fluid processing for waste remediation, desalination, and agriculture/aquaculture applications appear to have the greatest potential for significant near-term development. This study addresses the various uses that were identified, with economic emphasis on desalination and agriculture/aquaculture applications. Thermally enhanced oil recovery and supercritical fluid processing for waste remediation are subjects of separate feasibility studies, also being prepared by the INEL. 



\section{BACKGROUND}

As one of the prime contractors for the U.S. Department of Energy (DOE) at The Idaho National Engineering Laboratory (INEL), EG\&G Idaho, Inc. is presently evaluating potential direct uses for geopressured resources, as are a number of industries, firms, organizations, and educational institutions. In addition, EG\&G Idaho, Inc. (hereafter referred to as INEL) is spearheading the formation of an industrial consortium that would use the available energy in geopressured resources for multiple uses. Some of the uses under consideration include desalination, agriculture/aquaculture, sulfur frasching, the use of supercritical processes for detoxification of pollutants, brine production, power generation using natural gas driven engine generators or binary cycle power plants, food and other types of processing, chemical extraction, thermally enhanced oil recovery, and others.

A broad based infrastructure of designers and developers are available to apply their expertise toward the application of hydrothermal direct use projects for geopressured resources as a result of the development of hydrothermal energy. The use of hydrothermal resources in the United States (U.S.) for direct use projects was mostly limited to pool/health spa applications and for space and district heating before about 1973. With the oil price increases of the 1970s, the DOE initiated numerous incentive and technical programs that caused significant growth of the hydrothermal direct use industry. These activities resulted in numerous applications in agriculture, aquaculture, space conditioning, industrial uses, and various types of processing (Lunis and Lineau, 1988).

In recent years, DOE has been sponsoring the Geopressured-Geothermal Research Program, which includes the operation of three test wells in the Gulf Coast area. On behalf of DOE, the INEL provides technical support for the assessment and evaluation of the technical and production characteristics of this undeveloped resource. One result of these activities was the initiation of an industrial consortium at Rice 
University, January 10, 1990 with 65 participants from industry, educational institutions, the federal government, and state and development organizations. A following consortium meeting held September 11 th at the University of Texas in Austin, heralds the transition to commercialization for this undeveloped resource (Negus-de Wys, 1990). 


\section{APPROACH}

Interest is being expressed for a variety of applications that could utilize the thermal and hydraulic energy that is available in geopressured resources. As a result of that interest (and the continuing development of DOE's geopressured program), various organizations, institutions, firms, and individuals were contacted to aid in the identification of potential uses that would be of interest to industry. A literature search was conducted to determine what development has occurred in using geopressured resources and the types of applications utilized. From this preliminary investigation, Figure 1 was developed to identify numerous potential uses and their approximate process temperature requirements.

Additionally, a brief overview of the areas of interest and development concerns were identified in integrated geopressured applications.

Four areas of interest were selected to receive further evaluation. These areas are:

1. direct uses application

2. supercritical fluid processing

3. hydraulic and thermal energy

4. thermally enhanced oil recovery.

This report addresses the feasibility of applying geopressured resources to direct uses; the three remaining subjects are separate feasibility studies. Selection criteria were established to limit the number of direct use applications that would receive economic analysis. These criteria are:

- Industry interest

- The greatest near-term impact

- Technical feasibility of the application.

Economic analyses were performed for two direct uses that best fit the selection criteria. 

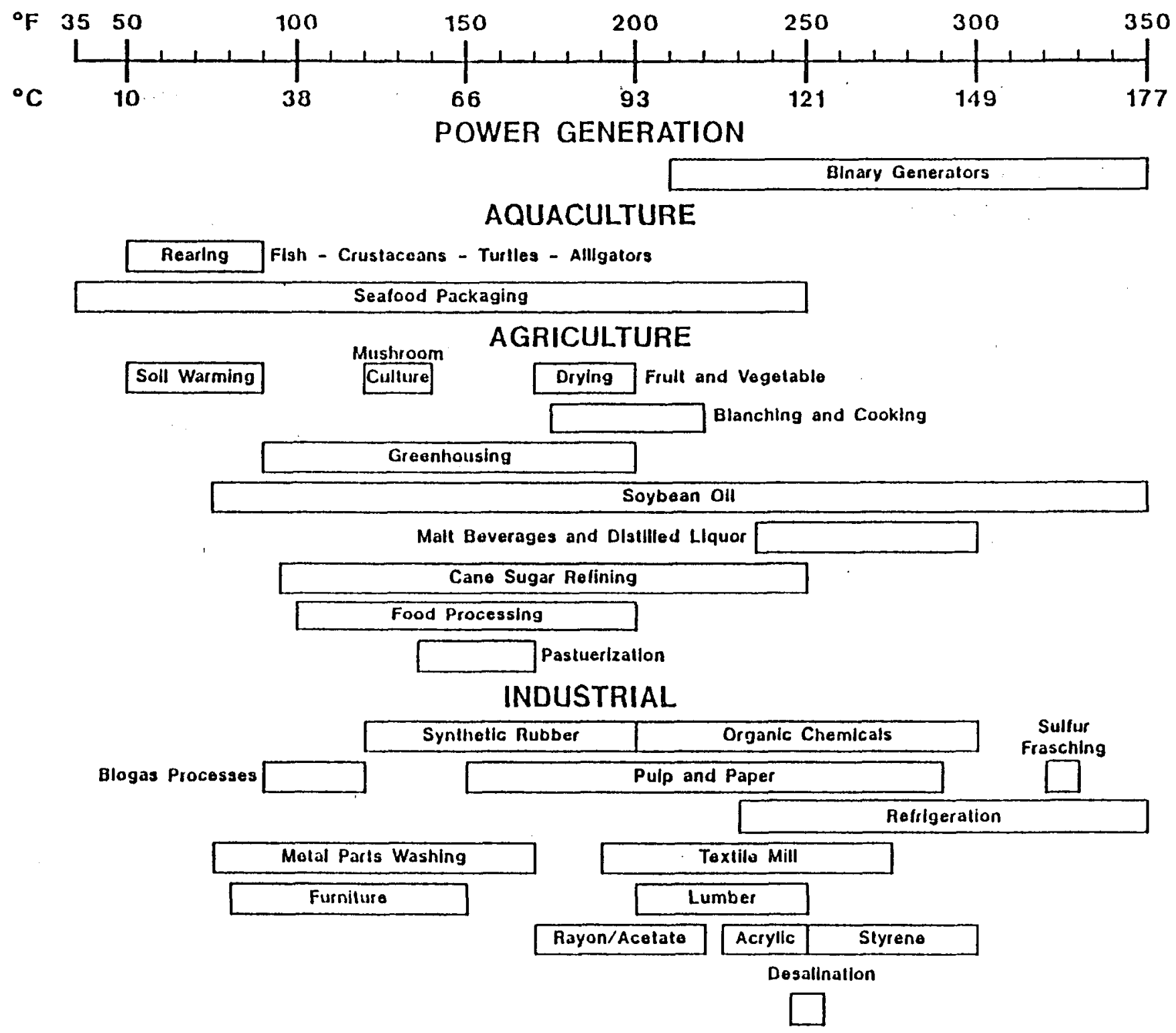

C90 0073

Figure 1. Potential geopressured applications and their temperature requirements. 


\section{FINDINGS AND CONCLUSIONS}

Applying geopressured-geothermal resources to direct use is feasible. of the various applications that were considered, desalination and agriculture/aquaculture appear to have high potential for near-term economic utilization. The sale of methane gas contained in the geopressured fluid will probably be accomplished irrespective of the applications selected to use the energy contained in the geopressured fluid. Additionally, commercialization would also include electric power generation, which was effectively proven at the DOE geopressure test facility at Pleasant Bayou, located about $50 \mathrm{mi}$ south of Houston, TX.

Evaluation of the various applications indicates that multiple uses incorporated at a common location increases the odds of profitability. For example, a complex served by a 20,000 barrels per day geopressured well that provides for the sale of the contained methane gas, the sale of potable water produced by desalination, bottled water, and the brines resulting from desalination will have a $15 \%$ discounted payback period of -4.3 years (Figure 2). The addition of an agriculture/aquaculture complex producing roses and catfish that is made up of a 4 acre greenhouse structure, service building, three $20-\mathrm{ft}$ diameter aquaculture tanks in an enclosure, and an $8 \times 45 \mathrm{ft}$ outdoor raceway would reduce the payback period to -4 years (Figure 3 ). However, when electricity production is added to the gas/potable water/bottled water/brine complex, the expected discounted payback period increased to more than 10 years when the electricity is sold for 6 cents $/ k W h$. If the complex is selling gas at market price, electricity at 6 cents/kWh, and includes an agriculture/aquaculture facility, the discounted payback is $>10$ years because of the high front end costs for the electric generation equipment and the relatively small return for the agriculture/aquaculture facility.

Practically, the actual installation will be determined by the specific geopressured resource. Utility restrictions and financial requirements have typically limited these developments because of the complexity of operation and management. 


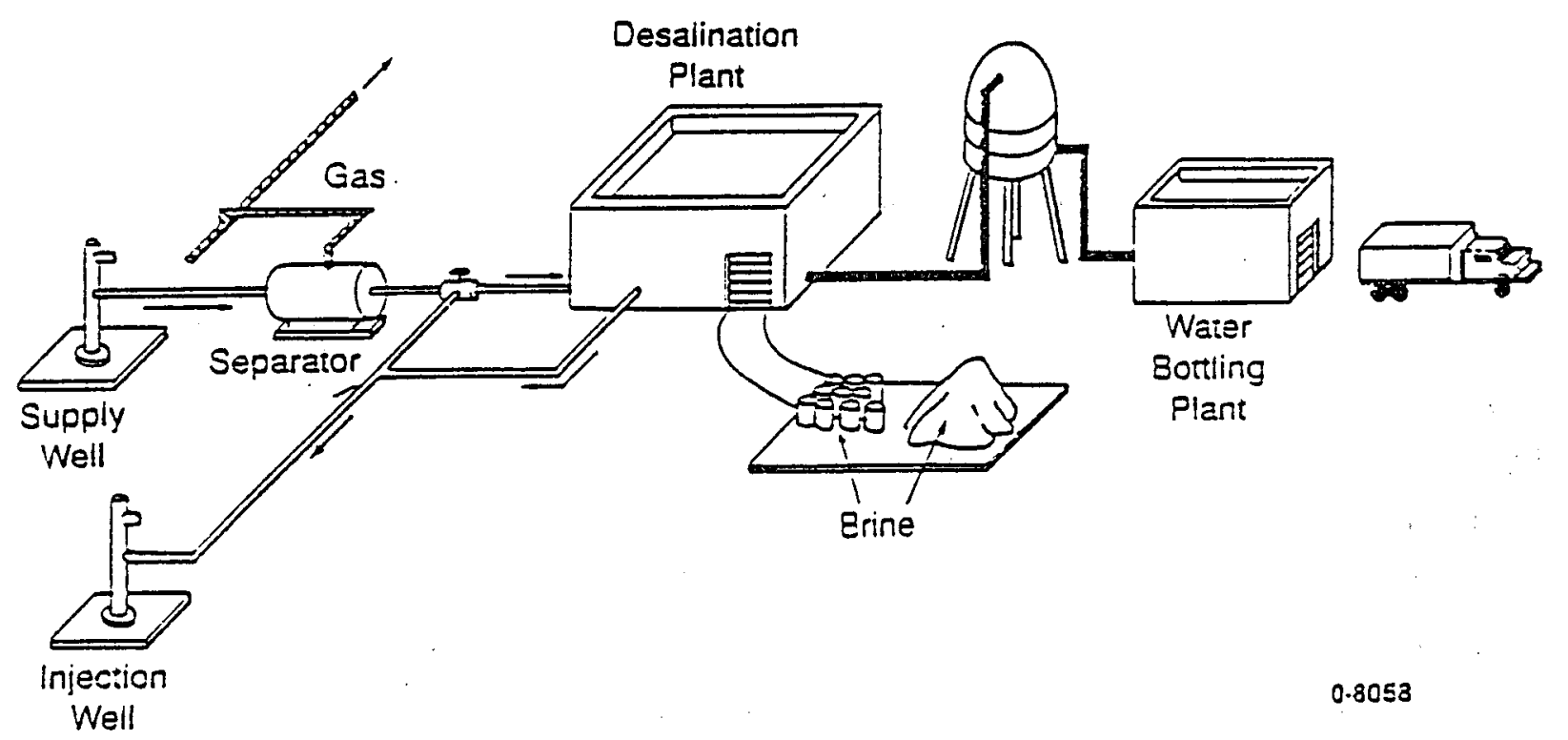

Figure 2. Feasible desalination facility.

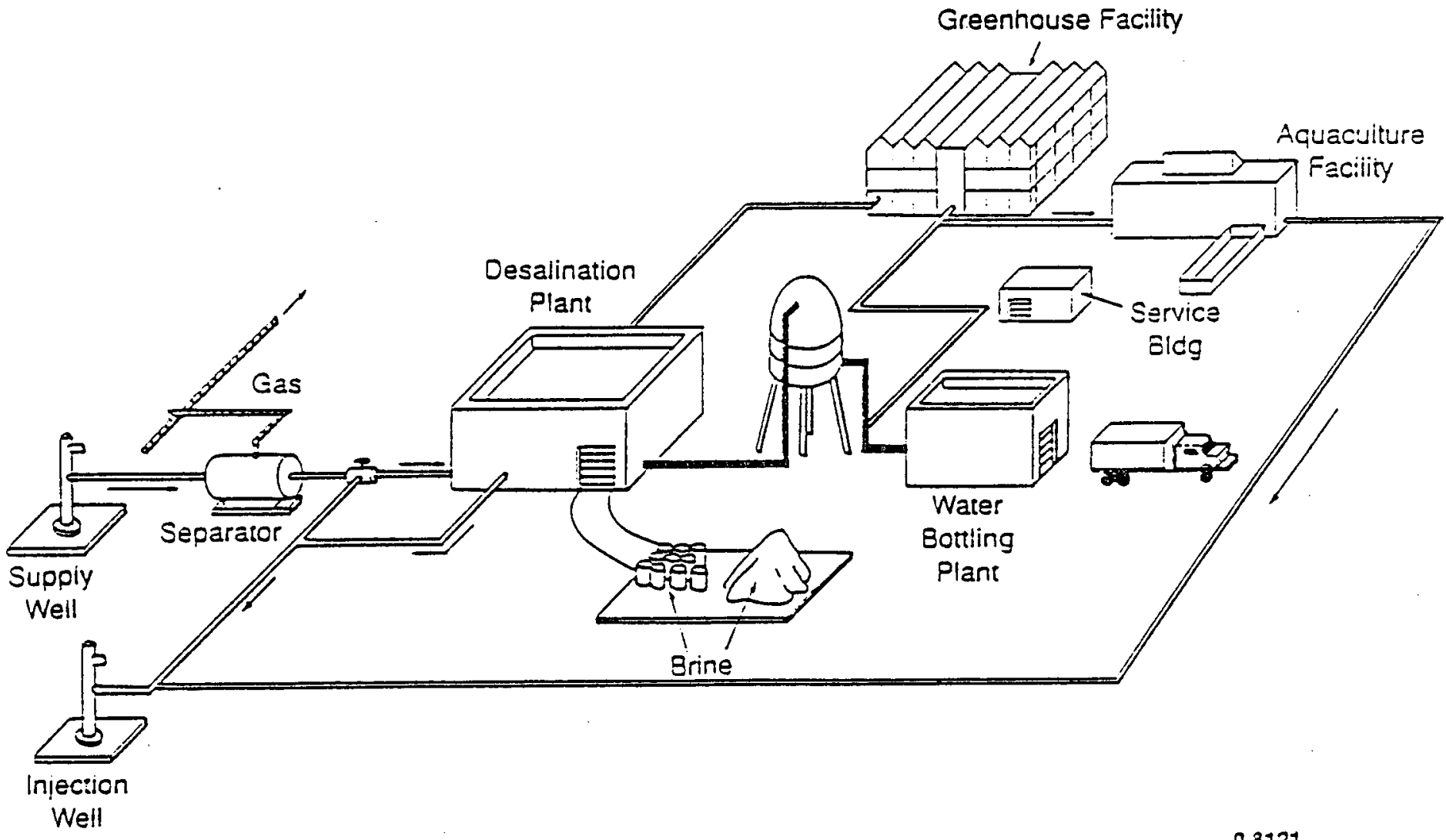

Figure 3. Feasible desalination/agriculture/aquaculture complex. 


\section{HYDROTHERMAL-GEOTHERMAL DEVELOPMENTS}

Various developments have been accomplished using hydrothermal resources for power production, industrial applications, processing, aquaculture/agriculture, heating and cooling, resort, and spa use. Direct use technologies have been proven to be technically and economically sound, with 45 states having experienced significant geothermal direct use development in the last 10 years. The total installed direct use capacity is $7.2 \mathrm{billion} \mathrm{Btu} / \mathrm{h}$ (2100 MWt), with an annual energy use of over 18,000 billion Btu/y ( 5 million bbl of oil energy equivalent). The significant increase in the use of hydrothermal energy for direct uses, especially since 1970, is displayed graphically in Figure 4 (Lienau, 1990). The rapid growth after 1970 is primarily caused by the oil price shocks of the 1970s and resultant Department of Energy development assistance programs. These same programs have resulted in technical expertise being available to apply the technologies developed for hydrothermal energy toward the energy found in geopressured resources. The principal sources of technical expertise are available at the Oregon Institute of Technology Geo-Heat Center in Klamath Falls, Oregon, the Idaho National Engineering Laboratory in Idaho Falls, Idaho, State energy offices, and from an infrastructure of developers, designers, and builders located throughout the United States.

Cascading of geothermal energy for numerous applications is more commonly practiced in nations other than in the U.S. For example, a geothermal power plant operated by Ente Nazionale per l'Energia Elettrica (ENEL), near Piancastagnaio, Italy, utilizes the waste heat industrially to provide additional employment in the region. A greenhouse complex that employs up to 500 people and a drying facility that employs up to 160 persons is being developed. Neither the greenhouse nor the drying facility would be profitable using fossil fuel for energy (Lund, 1987).

Another direct use application is located north of Tianjin, China, where $97^{\circ} \mathrm{C}$ fluids are effectively being used in cascaded farm operations 
for an extensive chicken hatching/rearing/processing facility, fish rearing, greenhousing, and a geothermal equipment research facility (Lienau, 1990).

Near Kawerau, New Zealand, geothermal steam generated by separate flash plants located in the geothermal field, is used in a variety of cascading operations that is probably the largest known industrial development. The steam is used to operate equipment, dry timber, process paper, and produce electric power in the Tasman pulp and paper company facility (Lienau, 1989).

In the Mostovsky Krasnodersky region of Russia, a village uses cascading applications from a geothermal well cluster that includes space heating, a livestock rearing facility, an industrial complex of furniture, feed, concrete, and hide reprocessing production heated irrigation fields, and fish culture ponds (Tikhonov, 1986). 


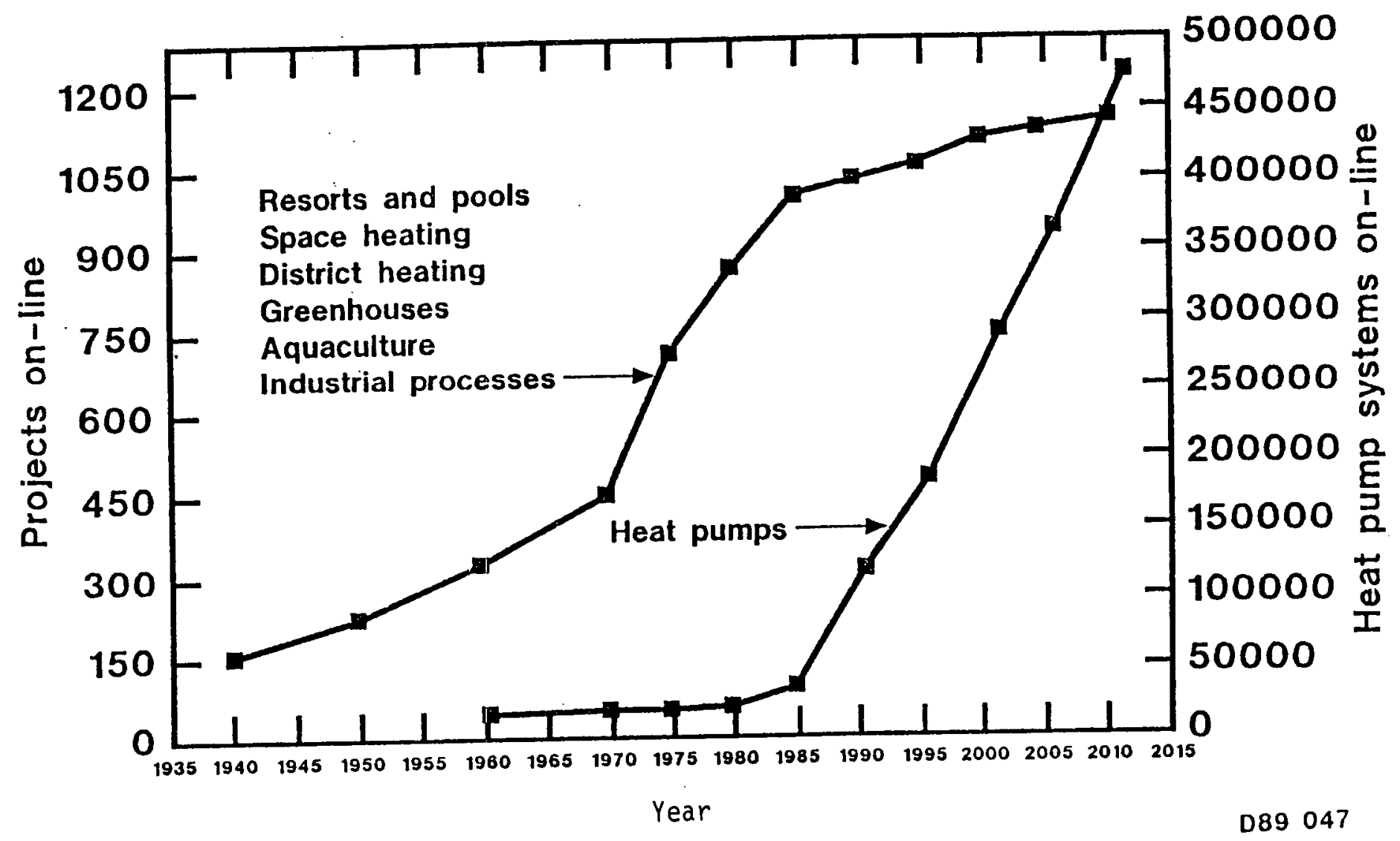

Figure 4. Growth in hydrothermal-geothermal applications (Lienau, 1990-1). 


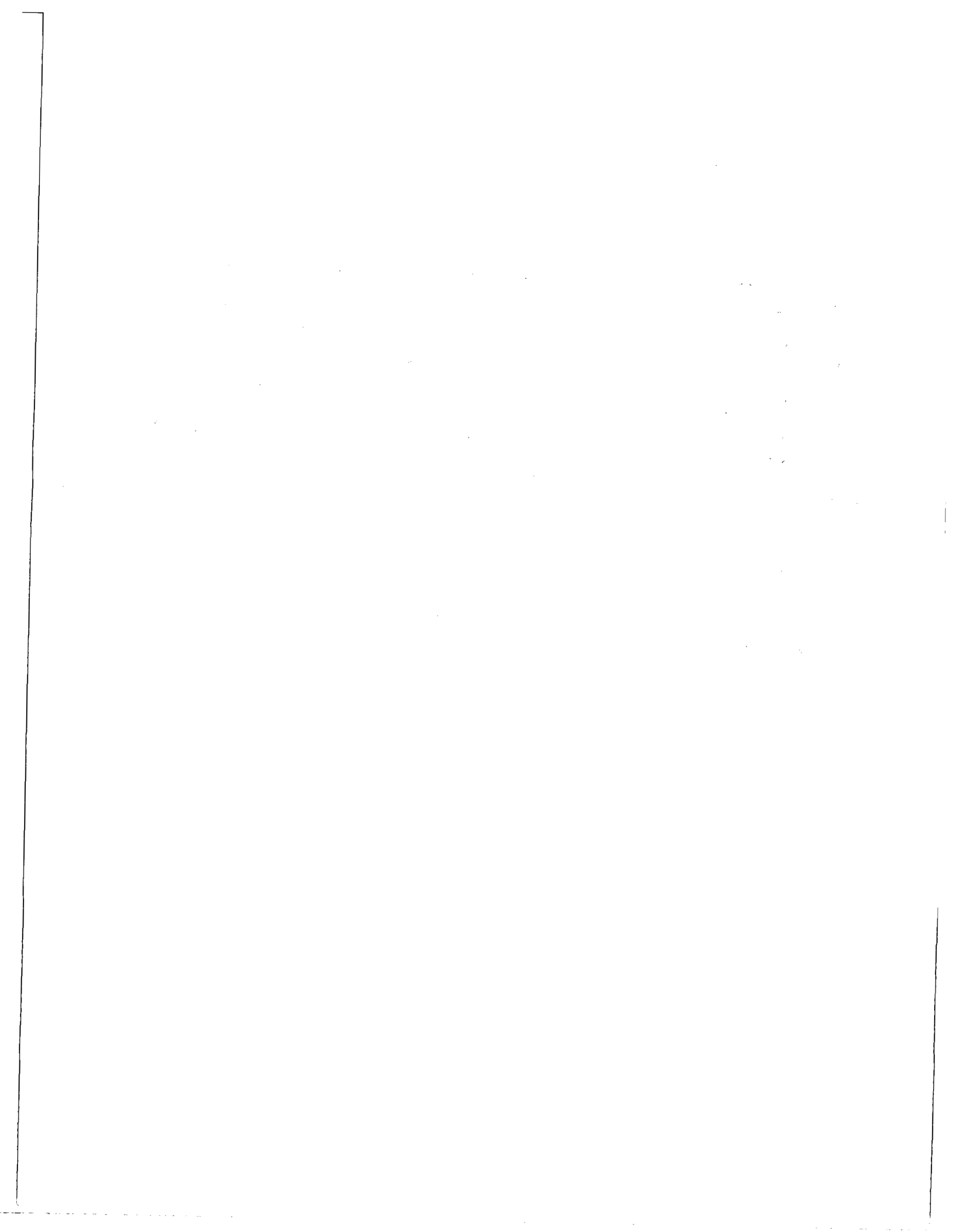




\section{THE GEOPRESSURED RESOURCE}

Geopressured resources vary considerably from hydrothermal resources. The contained gases, and higher well pressures contained in geopressured resources can significantly increase the opportunities and methods of application that can be developed. This section provides information about what the geopressured resource is, where it may be found, and applicable salient features and considerations.

Figure 5 displays the distribution of known hydrothermal resources in the United States. It should be noted that the present state of knowledge of geothermal resources of all types is very limited. It is known with reasonable certainty, that there are many more low-temperature $195^{\circ} \mathrm{F}\left(90^{\circ} \mathrm{C}\right)$ hydrothermal-geothermal occurrences than there are high-temperature $300^{\circ} \mathrm{F}\left(150^{\circ} \mathrm{C}\right)$ areas (Wright and Culver, 1989).

Geopressured-geothermal resources are a normal phase of basin evolution and are found in many locations throughout the U.S. (Figure 6) and the world. Geopressured resources have three energy forms: thermal, hydrautic, and methane gas. These three forms of energy can be converted to higher value forms of energy using the available technologies. The thermal energy can be converted to electricity using an organic Rankine cycle generator. The hydraulic energy can be converted to electricity with a hydraulic turbine. Dissolved methane gas can be separated and sold, burned, compressed, liquefied, or converted to methanol or to electricity by fueling a turbine (Negus-de Wys, 1989).

Geopressured resources normally exist between 12,000 to $20,000 \mathrm{ft}$ below the surface. Flow rates can vary between 10,000 to $40,000 \mathrm{bpd}$. Temperatures will range from 273 to $500^{\circ} \mathrm{F}$. Bottom hole pressures vary from 12,000 to $18,500 \mathrm{lb} /$ in. $^{2}$ absolute (psia). Salinity will be present in the amount of 20,000 to $200,000 \mathrm{mg} / \mathrm{L}$. Gas content will vary between 23 to 100 standard cubic feet (scf) per barrel of fluid (Negus-de Wys, 1989). 
Resource potentials are significant for hydrothermal resources, but are even higher for geopressured resources. According to Muffler (1978) of the United States Geological Survey (USGS), hydrothermal resources have energy potentials equal to 23,000 megawatts electric (MWe), \pm 3400 MWe, for 30 years. On the other hand, geopressured resources are estimated to contain from 23,000 to 240,000 MWe for 30 years in the Gulf region of the United States; Louisiana alone has the potential for 4100 to 43,000 MWe for 30 years. Geopressured resources are known to exist in other sedimentary basins of the U.S., such as the central valley of California. However, the USGS made no thermal potential estimate of those areas because of 1 imited knowledge at the time of preparation of Circular 790 (Muffler, 1978).

The current development of geopressured resources for direct uses is: limited to the workover of existing geopressured wells, which are the result of oil and gas field exploration and development. In 1981, between 2000 and 3000 geopressured wells would have been available each year in the Texas and Louisiana areas, respectively. Since that time, drilling activity has been significantly reduced, and it is estimated that $\sim 200$ to 300 geopressured wells are currently available each year. (It should be noted that not all of these wells would be available for development.) Typically, these wells are plugged and abandoned if sufficient oil and gas resources are not found. Increased oil field activity will obviously increase the number of wells drilled to geopressured zones.

Limited geopressured data is available. The University of Texas at Austin is performing a collocation study for Texas, and Louisiana State University is doing the same for Louisiana. Data are presented in the thermal enhanced oil recovery feasibility report from INEL.

Even more limited is the development of geopressured resources. Western Resource Technology, Inc., is actively developing geopressured wells; they have drilled one well to date and have 12 geopressured projects in various stages of development. British American Gas 
Production Co. has leased 4000 acres around the DOE Hul in Well site south of Lafayette, LA, and has options for another 10,000 acres. Their primary purpose is to obtain the gas contained in geopressured resources. 


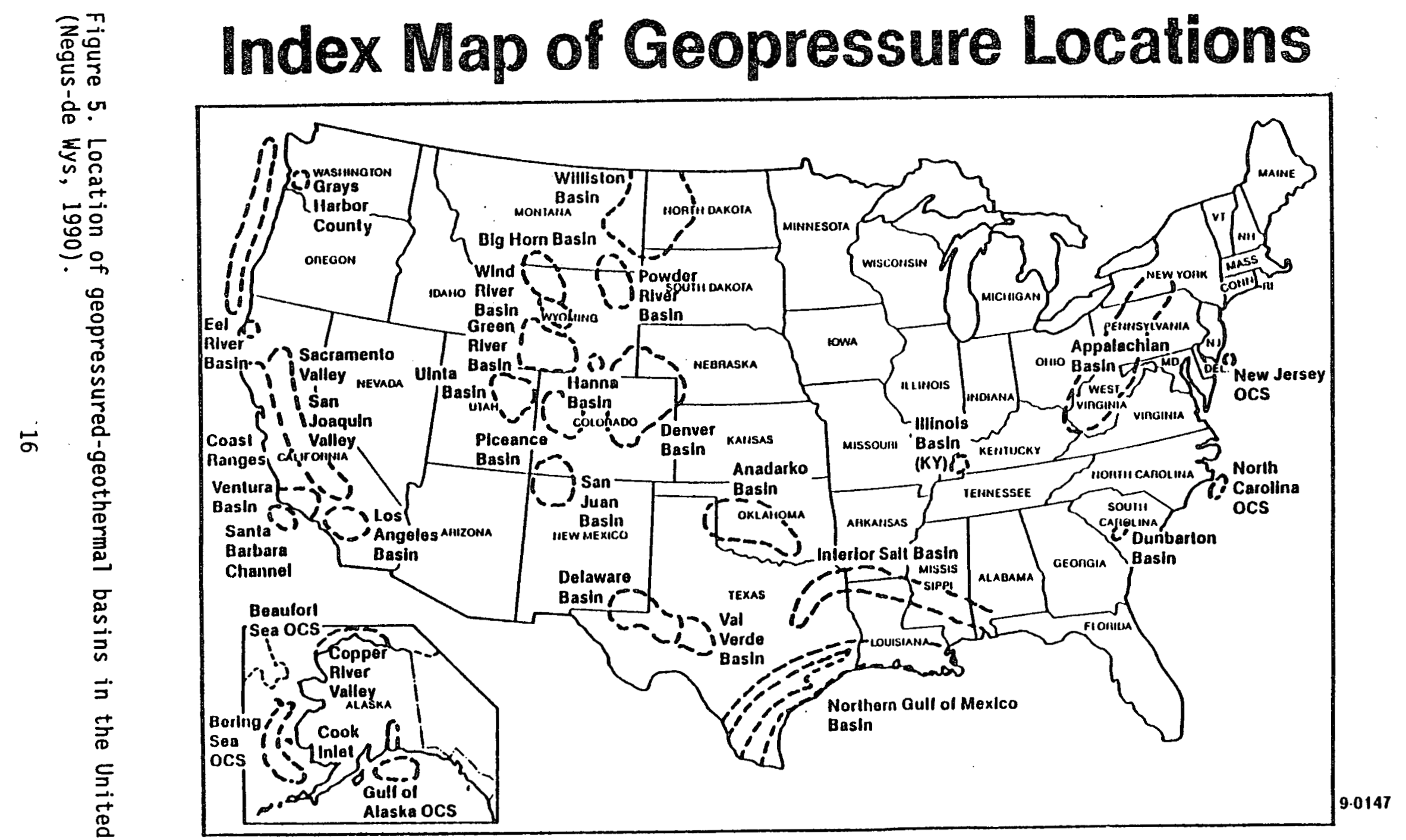




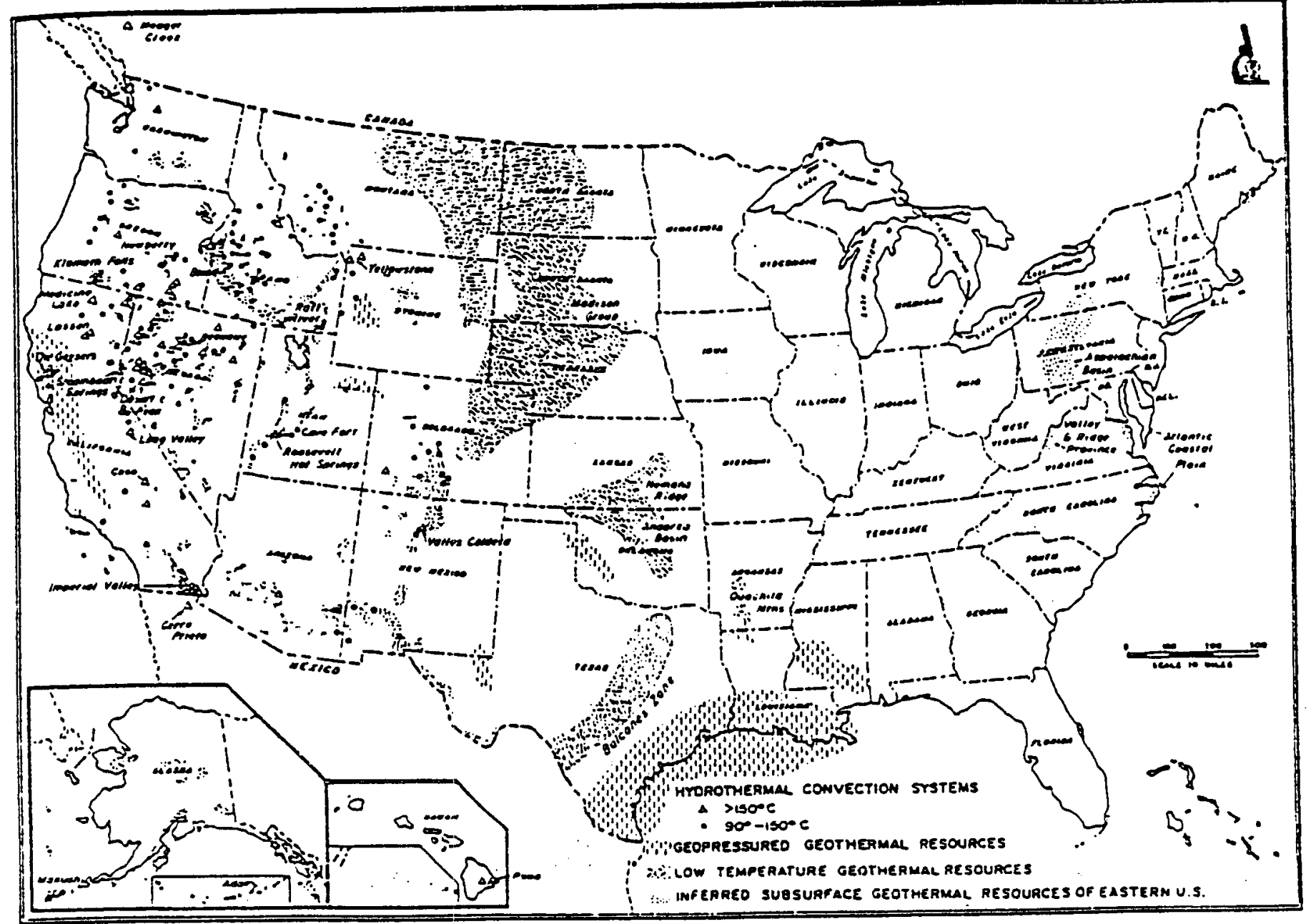

Figure 6. Hydrothermal resources in the United States (Wright and Culver, 1989). 



\section{GEOPRESSURED DEVELOPMENTS}

This section provides a summary of the current development status of using the energy found in geopressured resources. Although this study is directed toward direct uses, current information about power production is included. The use of geopressured resources will probably have the greatest potential for economic viability when an integrated operation is installed. The hypothesized facility in Figure 7 identifies the various applications under consideration. The actual installation will probably be a mix of the applications discussed on the following pages.

\section{Power Generation}

Power can be generated utilizing the thermal, hydraulic and methane energy contained in geopressured resources. About $1 \mathrm{MW}$ generated at the DOE Pleasant Bayou test facility located -50 miles south of Houston, TX. This facility incorporated a binary power plant and two gas fired generators to produce power, proving the commercial viability of this type of application. The sale of power between 5 and 6 cents/kWh appears to be the revenue needed for a profitable installation when properly coupled with other applications. The use of a modified Pelton turbine to capture the hydraulic energy has the potential to result in a decrease in the breakeven cost of electricity of between 2 and $2-1 / 2$ cents/kWh. This assumes a flow rate of 24,500 bpd that can sustain the operation of a 500 KW generator.

\section{Potential Industrial Applications}

Various industrial applications are being considered that utilize the thermal and hydraulic energy available in geopressured resources. Information about potential and current developments are contained in this section. The developer, location, development and any available cost information are provided in the following discussions. 


\section{Desalination}

Desalination is a proven technology using conventional energy forms. As the relative cost of water increases, desalination will become a more viable option - - not only to extract the potable water from geopressured resources in inland areas, but also from the ocean for near-coastal and other demands.

Fresh water can potentially be removed from geopressured fluids to meet critical freshwater needs in the water scarce regions of California, the lower Rio Grande Valley of Texas, and other areas, both nationally and internationally.

G. S. Nitschke (Boeing, WA) and J. A. Harris (Wichita State University) proposed a system that will use the pressure gradient of the reservoir to produce electricity by way of a pressure reduction turbine and generator combination. The natural gas would be separated for sale or on-site use, and the thermal energy would be used to produce potable water through a multi-effect distillation unit. In turn, the remaining saturated brines could be sold. The brine is ideal for solar ponds that utilize binary power generators, a method effectively proven in Israel. Solar pond power could be used for further water production in a conventional reverse osmosis desalination scheme fed with seawater. It is suggested that such a scheme could produce as much as $40 \%$ of the total water load in California (Nitschke and Harris, 1990).

F. J. Spencer (International Management Services) has identified six areas of use that he is encouraging for utilization of geopressured resources, particularly in the entire lower Rio Grande Valley, south TX, in the coming decade. The proposed areas are:

1. Recover dissolved methane and sell it as pipeline gas

2. Use the geopressured fluid or gas pressure or both to drive turbines for power production

3. Use the steam content of the geopressured fluid to drive conventional turbines for power production 
4. Use the heat in the fluid for many industrial processes

5. Use the fluid directly depending on salinity, for both aquaculture and industry

6. Desalinate the fluid and use the salts contained in the fluid as starting points for chemicals (Spencer, 1990). 


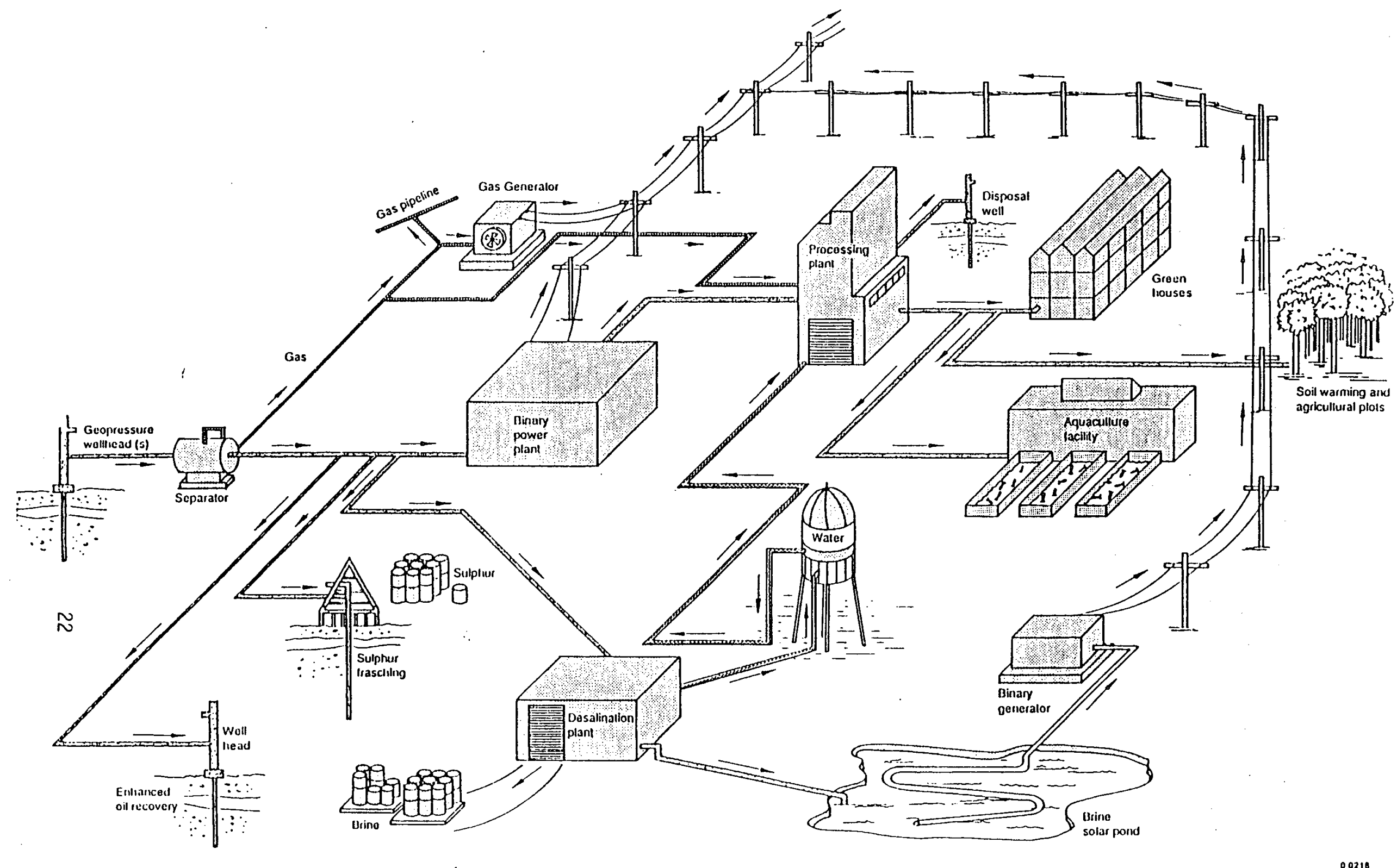

Fiaure 7. Potential geopressured integrated facility. 
The feasibility of utilizing geopressured resources to produce potable water by desalination appears to have high near-term probability of successful application, especially in areas of 1 imited water supplies such as the lower Rio Grande Valley region of south Texas, and the central valley of California.

Studies made by Dorfman and others during the early program years of the geopressured program indicate the Hidalgo county geopressured reservoir could sustain a brine flow of $16,830,000$ bpd without undue depletion over a 20 year 1 ife, and a brine flow of 45,600,000 bpd is estimated for Cameron and Hidalgo Counties (Dorfman and Morton, 1985). After salt removal, -1.15 billion gal/d of desalinated water could be recovered in a region that is characteristically low in water supplies (Spencer, 1990).

Both of these areas have geopressured basins that have the potential to be utilized for desalination. See Figure 6 for the approximate location of the Sacramento Valley, San Joaquin Valley, and Los Angeles Basins in California, and the Northern Gulf of Mexico Basin in Texas. As reported by the Department of Water Resources, State of California, in their drought Contingency Planning Guidelines for 1989, California realized a $\$ 2.4$ billion loss in the drought of 1976 to 1977 , and the current drought is worse. The suggestions for dealing with the drought are all conventional (more surface reservoirs, water purchases from surrounding states, etc.) Also, grandiose schemes such as digging a canal to the Columbia River and moving icebergs from Antarctica are being suggested by the City of Los Angeles. The Seattle Times, May 27, 1990, notes that under a scheme called the North American Water and Power Alliance, the Ralph Parsons Co., Pasadena, CA has developed a gigantic water-transfer $\mathrm{plan}$ that includes waterways snaking down the continent from Alaska, through Canada and the Northwest, to serve the freshwater needs of southern California. The estimated cost is $\$ 200$ billion. By contrast, Nitschke and Harris'(1990) proposed system would provide $\sim 40 \%$ of California's water demand at a cost of $-\$ 24$ billion (Table 1). This approach would include using geopressured resources found in the 
Sacramento Valley and San Joaquin Valley geopressured basins. The system would involve electricity production using pressure reduction turbine and generator combinations, gas use and sales, and freshwater production from the geopressured brines. The brine would be used in solar ponds for binary power production. 
Table 1. Proposed freshwater supplies from geopressured fluids for California

FACTOR

UNIT

No. of wells in Geop-Geo. field

1000

(1 $\mathrm{we} 11 / 30 \mathrm{mi}^{2}$ )

We1l production life

$10 y$

Tax rate to reflect

$25 \%$

federal assistance

Utilities prices

gas: $\$ 2.00 / \mathrm{Mcf}$

elec: $\$ .045 / \mathrm{kWh}$

water: $\$ 1 / 1000 \mathrm{ga} 1$

Lease costs

$1 / 8$ on gas rev.

only

Plug \& abandon costs (future use of well for

none

liquid waste disposal)

2nd Law efficiency on Rankine cycle (solar pond power prod.)

Desalination power (reverse osmosis; range: 3 to $80 \mathrm{Wh} / \mathrm{gal}$ )

Initial well/system elec (power added to gas-lift for brine transport)

Total solar pond area

$850 \mathrm{mi}^{2}$

Daily well-grid water (at height of prod.)

$80 \%$

$30 \mathrm{Wh} / \mathrm{gal}$

$14.4 \mathrm{MWh} / \mathrm{d}$

Solar pond water (at full production)

$530 \mathrm{E} 06 \mathrm{gal} / \mathrm{d}$

$\%$ of total CA water. (solar pond at full prod., based on 1985 consum.)

NOTE: The cost of the pipelines and the solar ponds power generation/ desalination facilities are est imated at $\$ 10$ billion each for a total capital investment of $\$ 24$ billion (including the $\$ 4$ billion for the 1000 well/system grid a $\$ 4 \mathrm{million}$ each). Note that no benef it allowance is made for either using wells for waste disposal or earthquake control possibilities. 


\section{Gas Use and Sales}

Gas contained in the geopressured fluid can be separated, used directly, or sold to a pipeline company, or all three. This was effectively accomplished at the DOE Pleasant Bayou facility. The gas was used to drive two gas engine generators. The gas could also be used for refrigeration and to drive pumps.

The methane gas contained in geopressured fluids increases the profitability of utilizing a geopressured resource and increases the options that are available for direct uses. The contained gases can vary between 23 and $120 \mathrm{scf} / \mathrm{bbl}$ of fluid. The Pleasant Bayou facility produced $23 \mathrm{scf} / \mathrm{bbl}$, which was effectively used to drive two $325 \mathrm{~kW}$ gas engine generators. For an integrated facility, the selection of applications will determine the extent to which the contained gas will be used to produce electricity, power equipment, or be sold directly to a gas pipeline company. Another consideration is whether or not the sales price for electricity is lower or higher than gas prices.

Electricity purchased from HL\&P costs between 10 and 12 cents/kWh. Accordingly, if the power needs of an integrated facility are large enough, it could be economically feasible to install a gas engine, a binary cycle power plant, or a hydraulic turbine to meet facility needs.

\section{Pollutant Removal}

The Air Force Engineering and Services Center, the DOE Hazardous Waste Remedial Actions Program, and the Los Alamos National Laboratory are investigating the use of supercritical water (above $705^{\circ} \mathrm{F}$ and $3208 \mathrm{psia}$ ) processes for the destruction of hazardous wastes (Rofer, 1990). Processing methods appear suitable but require additional development. The feasibility of the utilization of the energy contained in geopressured resources for supercritical water processes is under investigation at the INEL.

Groundwater Services, Inc. Houston, TX, is performing a pilot study for the recovery of non-aqueous phase liquids at a superfund site, and the evaluation of geopressured-geothermal brine as a potential remediation 
evaluation of geopressured-geothermal brine as a potential remediation technology. Dense non-aqueous phase liquids (DNAPL) greatly complicate groundwater remediation because the heavy DNAPL will sense and follow topographic lows within an aquifer system, and because DNAPL is difficult to extract using conventional pumping methods. These problems are now being observed at the Motco Superfund Site near Houston, TX, where DNAPL is present in a shallow surficial aquifer. As observed in pilot test activities, waterflooding and well-bore vacuum enhanced recovery increased recovery rates (Conner, 1990).

The use of geopressured fluids for the remediation or removal of hazardous wastes, or both, appears to have significant potential for development, especially considering the increasing emphasis on controlling hazardous wastes. Accordingly, a separate feasibility study is being prepared by the INEL.

\section{Thermal Enhanced 0il Recovery}

Geopressured resources, often encountered while drilling for $0 i 1$ and gas, can provide hot brines under pressure to flood reservoirs containing medium or heavy oils to enhance recovery. The INEL is proposing a program for the thermal enhanced recovery of heavy oil from the Alworth Field in the "Mirando" trend of south Texas. It is not possible to consider a hot water-steam type flood in this part of Texas because of the lack of steam quality fresh water; however, geopressured brines can be considered. In the San Joaquin Basin of California, cyclic steam injection has been used successfully but is now under scrutiny because of the poliution generated by the equipment used in producing the steam; in contrast, using geopressured brines offers an environmentally clean process (Negus-de Wys, 1989).

The potential impacts and feasibility appear very high. Industry is proposing a demonstration project. Accordingly, the INEL is preparing a feasibility study. 


\section{Sulfur Frasching}

Sulfur can be recovered from salt dome deposits using a process devised by Dr. Herman Frasch. This process was perfected commercially in 1903. The technique melts the sulfur while still underground in porous limestone and calcite deposits. Superheated water $\left(320\right.$ to $\left.330^{\circ} \mathrm{F}\right)$ with pressures of 125 to $200 \mathrm{psi}$ is injected into the sulfur deposits. As the sulfur melts, it is forced to the surface where it can be transported in liquid form, solidified, or made into flakes or pellets (Carlson, 1976).

Adequate pressure and temperature are available in geopressured fluid to perform sulfur frasching with geopressured fluid. The production of sulfur is limited to three producers in the U.S.; Freeport-McMoran, Inc., New Orleans, LA, Pennzoil Sulphur Company, Houston, TX, and Texas Gulf Chemical, Houston, who is phasing down its sulfur operation. Freeport-McMoran needs sulfur mostly for their phosphate fertilizer production. They have two mines on-shore near New Orleans, LA, and one offshore. Freeport-McMoran recently announced the first sulfur discovery since about 1970 at Main Pass, offshore Louisiana.

The production of sulfur is very capital intensive, precluding small operations. For example, the cost of developing the newly found Main Pass deposit, located in $220 \mathrm{ft}$ of water, will be $-\$ 554$ million. Transportation is about one-half the cost of production. In the 1950s, Freeport-McMoran obtained a patent for the use of salt water in the Frasch process at one of its locations. In theory, there are no basic physical, chemical, or biological restrictions to this process, and although there will be a slight entrapment of salt into the final well-side product, the advantage of not having to pipe or ship quantities of freshwater to the rig makes this a minor price to pay. Despite the fact that the patent expired almost 10 years ago, Freeport-McMoran is the only company currently using this technology (Darling, 1989). Accordingly, the potential exists to use geopressured fluids directly in the Frasching process.

Sulphur deposits appear to be very 1 imited; however, they are located in regions that may contain geopressured resources. The potential for 
contribution to the sulphur industry appears very high with the Frasch process if a constant supply of superheated water $\left(320\right.$ to $\left.330^{\circ} \mathrm{F}\right)$ under pressure (125 to 200 psia) can be met by a geopressured resource.

Frasch mining takes place in five countries: Poland, United States, Canada, USSR, and Iraq. Poland is the largest producer and has the largest reserve base. The non-U.S. Frasch producers are state controlled, volume oriented, and do not have the same motives as privately owned organizations in the U.S. The result is a concentration of market pressure on U.S. producers during periods of market weakness (Eckert, 1987). If geopressured fluids could be effectively used for Frasching, the market position of the U.S. could be significantly improved.

A feasibility analysis would be in order to establish the extent of the impact of using geopressured resources for frasching. This effort could include colocation of geopressured resources to known sulphur deposits, and investigating the feasibility of using geopressured brines directly in the process, using heat exchangers where fresh water would be available or produced by desalination from geopressured brines.

\section{Petroleum and Natural Gas Pipelining}

Petroleum and natural gas pipelining require large quantities of energy to operate the systems. Pipeline companies operate throughout geopressured areas and could benefit from technology developments using the energy available in geopressured resources (Carlson, 1976).

Geopressured resources could be used as an energy source for the transport of petroleum and natural gas because oil and gas wells are often located near geopressured resources; however, this investigation did not evaluate the potential or investigate the feasibility in-depth. No industry interest has been noted from contacts, through current program activities, or the geopressured industrial consortium. It is recommended that additional effort be expended to determine potential impacts and feasibility. 


\section{Coal Desulfurization and Preparation}

There are a number of processes that are used to process solid or liquid fuel from high-sulfur, high ash coal. Much of the lignite found along the Texas Gulf Coast region is either high sulfur, high ash, or both. These types of processes require large quantities of process heat, pumping, and conveying; geopressured energy could be applicable to all or part of these energy needs (Carlson, 1976).

Processes used for coal desulfurization and preparation have heat requirements that can be met with geopressured resources. The extent to which these needs can be fulfilled using geopressured fluids remains to be investigated. No industry interest has been expressed to date, but pending geopressured industrial consortium activities may result in stated industry interests. The colocation of geopressured resources to this industry, areas of applications, and potential uses could be investigated to ascertain potential impacts and feasibility.

\section{Lumber and Concrete Products Kilning}

Typical kilns for lumber drying and concrete products require low-quality steam or heated air. These facilities could easily operate with the available heat in geopressured resources (Carlson, 1976).

Lumber and concrete products kilning require low-quality steam or heated air for processing. Geopressured resources contain temperatures adequate to meet the needs of this industry. To date, industry has expressed no specific interest, and the extent of the potential utilization and impact remains to be investigated.

\section{Paper and Cane Sugar Industries}

Numerous pulp and paper mills exist in geopressured regions. About 38 pulp and paper mills are located in Texas and Louisiana. Eleven mills in these two states are located in potential geopressured regions and have a gross energy consumption of about 78 trillion Btu/year. Louisiana also has about 43 raw sugar mills and six sugar refineries that consume over 12 trillion Btu/year (Hornburg, 1975). Although these data were assembled in 1975, they provide a relative value for current considerations. 
The overall conclusion of a study made by DSS Engineers, Inc., Ft. Lauderdale, FL, (Hornburg, 1975) is that utilization of thermal energy from geopressured fluid in pulp and paper mills and new sugar refineries is technically sound and economically feasible, providing that the natural gas and the pressure contained in the fluid is recovered concurrently. Studies on specific sites and facilities are needed to refine and verify the information developed.

\section{Chemical Processing}

An analysis made by DDS Engineers, Inc., Ft. Lauderdale, FL, (Hornburg, 1975) of the processes used in the industrial organic chemicals group showed that acetic acid, acetic anhydride, ethyl alcohol, and isopropyl alcohol can be produced with almost all the energy needed being supplied by geothermal fluids. A similar analysis of the industrial inorganic chemicals group revealed that sulfur, bromine, aluminum sulfate, and alums could be produced with energy supplied by geothermal fluids. Additionally, it was found that large quantities of low-level heat are used to concentrate sodium hydroxide, which is produced concurrently with chlorine (Hornburg, 1975).

The energy contained in geopressured fluids can meet the needs of numerous chemical processes that occur in geopressured regions. Industrial organic chemical processing could amount to -30.5 trillion Btu for production in Texas and Louisiana (1980 basis). For inorganics, an estimated 60 trillion Btu/y could be utilized (Hornburg, 1975). It is recommended that this potential area of use receive investigation.

\section{Chemicals in Geopressured Fluids}

Geopressured fluids contain varying amounts of various chemicals. Table 2 identifies the contents and their amounts found in an analysis of the Pleasant Bayou, TX, geopressured we 11. Certain of these chemicals may be extracted to add to the overall economics of a geopressured facility.

Wherever the geopressured fluid shows bromine concentrations of at least 60 to $70 \mathrm{ppm}$, a proven recovery process (Figure 8) may be utilized to release the bromine in pure form. Bromine is a vital ingredient in photographic 
films. Today, nearly half of the bromine supply is derived from seawater, and the other half comes from deep underground brines in California, Utah, and Arkansas. In a typical case, a single well flowing at a rate of 20,000 bpd, and a bromine content of $65 \mathrm{ppm}$ could yield $\sim 450 \mathrm{lb}$ (100\% extraction) of bromine, with a market value of $\sim \$ 250 /$ day. The concentrated brines from desalination effluent are rich sources of various chemicals (Figure 9) whose economic extraction may be best accomplished by way of accumulation in solar ponds from which harvesting and processing of the various salts could be undertaken as at the Great Salt Lake in Utah. 
TAble 2. Pleasant Bayou brine analysis.

DESCRIPTION

Spec Gravity

c $60^{\circ} \mathrm{F}$

Total Dissolved Solids

Alkalinity $\left(\mathrm{mg} \mathrm{C}_{\mathrm{a}} \mathrm{CO}_{3} / \mathrm{L}\right)$

Ammonia

Arsenic

Barium

Boron

Bromide

Cadmium

Calcium

Chloride

Chromium

Copper

Fluoride

Iodide

Iron

Lead

Lithium

Manganese

Magnesium

Mercury

Nickel

Potassium

Silica $\left(\mathrm{SiO}_{2}\right)$

Sodium

Strontium

Sulfate

Tin

Zinc

\section{Content}

$(\mathrm{MG} / L)^{\mathrm{a}}$

133,900

301

86
$<0.5$
767
25
75
$<0.1$
7,960
72,000
$<0.1$
$<0.1$
1.6
23
45
$<1$

32
16
604
$<0.005$
$<0.25$
561
108
36,700
850
6
$<0.25$
0.56

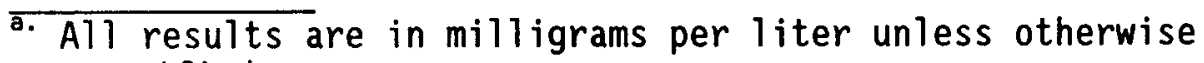
specified.

Sampled after choke (Negus-de Wys, 1990). 


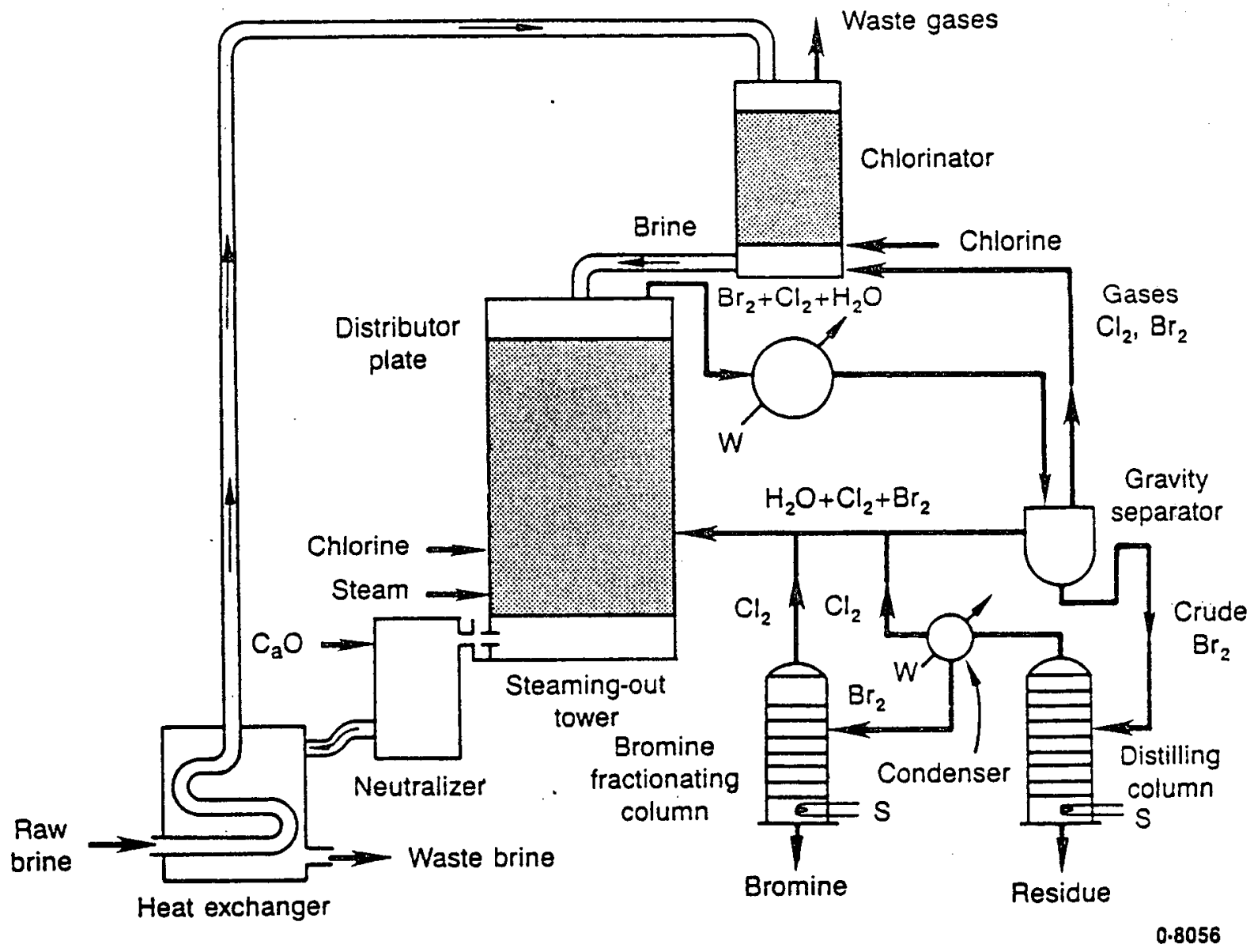

Figure 8. Extraction of bromine from seawater or selected brines (DOW process, modified). 


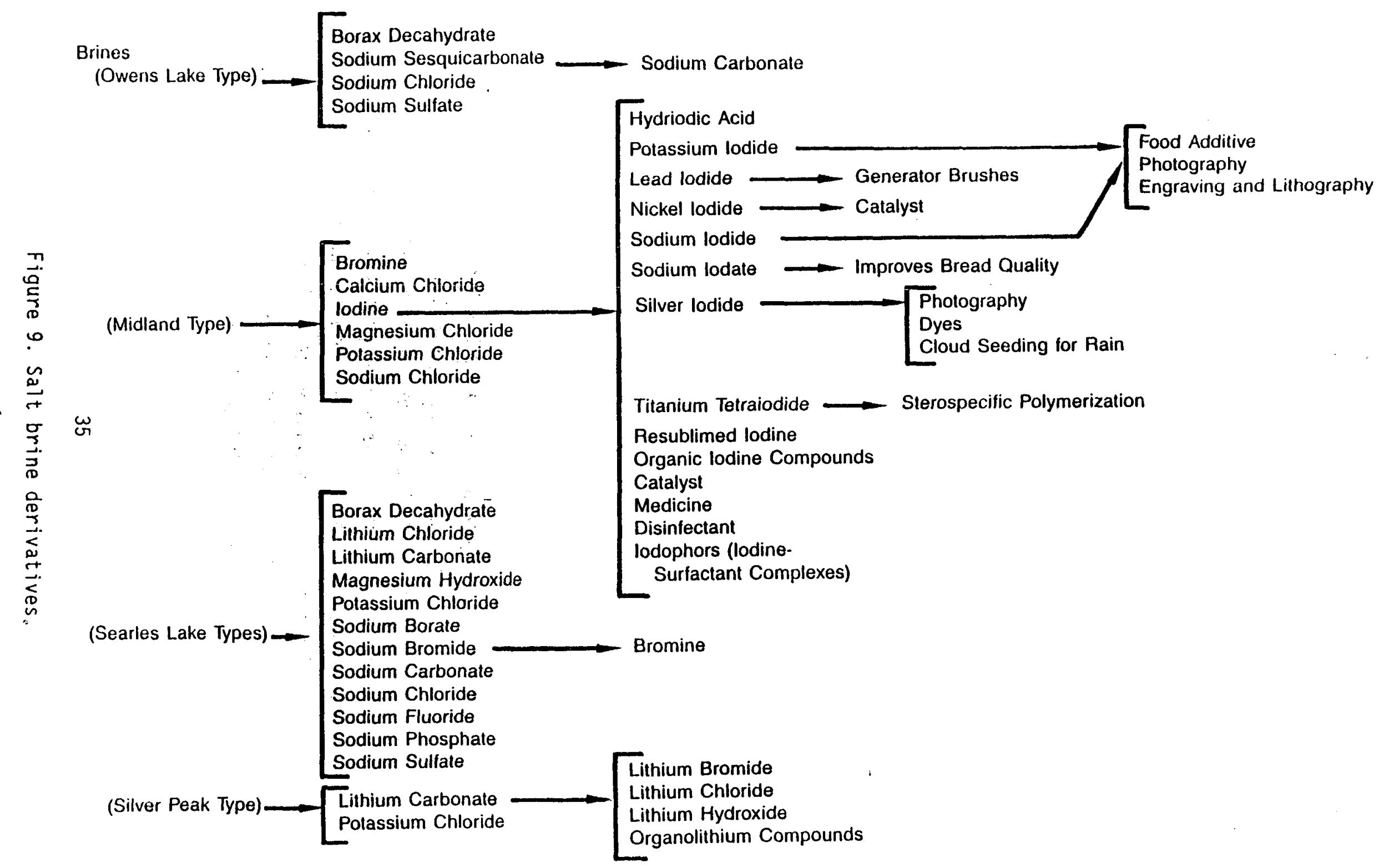




\section{Potential Agriculture/Aquaculture Applications}

Various agriculture/aquaculture applications are under consideration that could use the fluids and energy found in geopressured resources. One or more of these applications can be installed in cascaded uses where the hot fluids that have been used for one process are then used in another application.

Current commercial production of both aquatic and agriculture products is commercially limited by cold winter weather when growth rates can be severely hampered by lowered and fluctuating temperatures. This in turn disrupts established markets, often making it necessary to create new markets when the products are once again available. For example, alligators grown in Louisiana achieve a marketable length of $\sim 4 \mathrm{ft}$ in 3 years with ambient temperatures. If the surrounding air and water temperature is maintained near $90^{\circ} \mathrm{F}$, alligators will grow to $7 \mathrm{ft}$ in the same 3 year period, doubling the potential income (Ray, 1990). Fish growth rates can be increased 50 to $100 \%$ with constant temperatures. Thus, utilizing the heat and fluid available in geopressured resources for agriculture/aquaculture applications can significantly improve growth rates, marketability, and profits. A brief summary follows of some agriculture/aquaculture applications under consideration for use at geopressured resources.

\section{Greenhousing}

A large variety of fruits, vegetables, flowers, and ornamentals can be grown in geothermally heated greenhouses; this has been proven using hydrothermal resources. The type of product selected for growth at a geopressured site will depend on the market. Heat from a geopressured resource would be utilized in greenhouses by separating actual heating equipment from the geopressured fluid. For operation purposes, a heat exchanger is placed between two circulating loops, the geopressured loop and the clean loop. Heating equipment could be finned pipe, unit heaters, finned coils or soil heating, depending on growers choice and resource temperature.

The potential for greenhousing with geopressured resources is very promising in Southern Louisiana and Southern Texas. It is recommended that 
DOE make a well available to a developer for demonstration of the validity of using geopressured resources for this type of use.

The negative impacts of cold weather on the citrus industry and disruption of the marketing of agricultural crops continues to result in the considerable interest by industry, universities, and market development organizations, especially in Louisiana and Texas. Agro-Flex, a broad-based 13 parish nonprofit rural economic development program for Southwestern Louisiana, is continuing to conduct numerous market studies to select appropriate crops and to align the interested organizations and industry to aid in development in their geographic region. Victor Bendel Co., Hindale, IL, is a frozen food brokerage that is seeking ways to curtail frost damage to citrus trees and has expressed interest in using geopressured resources for this application. Riviana Foods, Houston, TX, is principally involved in rice processing and has expressed interest in using the geopressured energy for their plant needs. Although their demand for heat occurs over a relatively short period of time, in the summer when rice is harvested; they may have different operations in the future and would consider using geopressured energy. Lou Ana Foods, Inc., Opelousas, LA, has expressed interest in verifying the use of geopressured energy for greenhousing of various crops.

\section{Production Plot Warming and Frost Protection}

The effects of frost can be mitigated, and the growing season for different agricultural products can be extended by applying heated water to warm the soil through underground piping or above ground sprinkler systems and distribution systems, or both. Hydrothermal fluids (depending upon their chemical content) can be applied directly to agricultural plots; this was effectively proven in the Raft River Valley of southeastern Idaho where DOE operated a geothermal test facility in the late 1970s and early 1980s.

The potential to reduce the impact of frost upon agricultural crops, especially citrus trees, and to extend growing seasons for various crops in order to improve marketability appears very high in southern Texas and southern Louisiana where geopressured resources are potentially available. 
The University of Southwestern Louisiana proposes to use geothermal heat from a geopressured facility to protect and extend the production of citrus crops. An open field unit would be developed with several experimental plots. One field would have much higher densities than those used in conventional citrus orchards to reduce heat loss from air movement among the trees; another would be heated by installing a subsurface system of hot water piping using geothermal fluids, and a third would be heated using a warm water sprinkler system (Huner and others, 1990).

Greenhouse production of citrus has been practiced on an extremely limited scale with enough success to warrant its investigation. Because some thermal protection of citrus is provided by greenhouses alone, only a minimal amount of supplemental heat would be necessary. The combination of greenhouse citrus production and the utilization of geothermal heat commands further study.

The University of Southwestern Louisiana proposes to utilize four greenhouses, each planted with a single cultivar of citrus at high density population to compare and evaluate geothermal heat as a practical means of providing greenhouse heat. Three methods of heating would be used; (a) a subsurface network of hot water piping to provide soil warming and radiant heating, (b) a hot water mist sprinkler system geared primarily toward protection, and (c) hot air to be supplied in a duct system that can be supplemented by solar radiation (a solar system is presently under construction in association with the university's Center for Greenhouse Research) (Huner and others, 1990).

\section{Rearing of Fish, Crustaceans, Exotics, Turtles, and Alligators}

Aquaculture involves the raising of freshwater or marine organisms in a controlled environment to enhance production rates. The principal species being raised are catfish, bass, tilapia, sturgeon, shrimp, and tropical fish. Redfish and striped bass are also being reared. Aquaculture is one of the fastest growing applications for using low-temperature geothermal energy (Lienau, 1989). This growth is in response to an ever increasing demand for fish products, especially in Japan and other Asiatic countries. Controlled rearing temperatures increase growth rates by 50 to $100 \%$; thus, increasing the 
number of harvests per year. In addition, the use of geothermal fluids in controlled rearing has been proven to reduce the incidence of disease.

The use of geopressured fluids to maintain optimum growth temperatures for fish, crustaceans, exotics, turtles, and alligators has a very high potential for application in Southern Texas, Southern Louisiana, and other areas where geopressured fluids are potentially available. Alligator culture is an emerging and lucrative industry. As previously noted, maintaining growth temperatures at $\sim 90^{\circ} \mathrm{F}$ can cause an alligator to grow to $\sim 7 \mathrm{ft}$ in 3 years, whereas those grown under ambient conditions only reach a length of $4 \mathrm{ft}$ in the same time period. Fish Breeders of Idaho is planning to utilize their $90^{\circ} \mathrm{F}$ hydrothermal resource to evaluate the rearing of a small quantity of alligators (Ray, 1990). The University of Southwestern Louisiana is proposing to determine the cost effectiveness of using waste heat from a geopressured facility to warm alligator cultivation units, to evaluate the use of biofilters to control waste levels in culture water, and to observe the benefits of eliminating cold shocks from periodic water changes (Huner and others, 1990).

Grant Emery, Sun City, CA, is seeking a site of 600 to 1000 acres to rear 8 to 9 million tilapia/a year for sale in the east coast market. He is interested in using a combination of solar and geopressured energies to maintain $85^{\circ} \mathrm{F}$ temperatures for the tilapia rearing.

Considerable interest has been expressed by various members of the Texas Aquaculture Association in the use of "thermal refuges" to shelter pond-reared fish during extreme winter conditions. One approach involves placing a cover over suspended cables on a corner of a pond forming a triangular shelter area. The cover is spread 1 to $2 \mathrm{ft}$ above the surface of the pond, and on the side facing the pond. The cover is extended underwater and weighted in order to form a wall between the refuge and the open pond. A space is left for fish passage. Warm water is introduced to provide heat in the sheltered area, providing a warmed water refuge for the pond fish (Rafferty, 1990). Geopressured heated water can be utilized for this type of application. 
Snapping turtles are important components of the aquatic fauna throughout the south. However, exploitation of snapping turtle resources has made them scarce and in great demand. Research has indicated that it may be feasible to cultivate them in the same way alligators are cultured. The University of Southwestern Louisiana is proposing to use a reptilian unit to investigate snapping turtle growth in culture units (Huner and others, 1990).

The soft-shell crustacean industry in Louisiana is becoming an important part of the aquaculture industry. One of the principal problems is the high cost of heating to maintain optimum growth temperatures (75 to $81^{\circ} \mathrm{F}$ ) during the winter months. The University of Southwestern Louisiana is proposing to use part of an intensive aquaculture unit to examine the cost effectiveness of using geothermal heat to heat soft-shell crustacean units and to assess the feasibility of cultivating high value ornamental fishes in such systems (Huner and others, 1990).

Fingerling food fishes including tilapia, catfish, and striped bass are typically cultivated in open earthen ponds. This places them at considerable risk to predation, especially by birds. Winter water temperatures also curtail their growth, or in the case of tilapia, cause death when temperatures drop below $50^{\circ} \mathrm{F}$. Intensive culture in enclosed units offers the potential for protection from predators, and an enhanced growth rate, by controlling water. temperatures. The University of Southwestern Louisiana proposes to examine the cost effectiveness of using geothermal heat to heat a finfish fingerling unit, and to assess the feasibility of "head starting" fingerling food fish by cultivating them intensively during the cold months. Integration of ornamental fish into the system during warm months would be investigated (Huner and others, 1990).

The capability of growing exotic tropical species such as freshwater prawns and tilapia in heated nursery systems has been proven. These systems often use floating water hyacinths to provide substrate for the animals and remove waste products from the water. None of these systems have been economical because of the cost of heating the system, as well as the lack of use of water hyacinths. In southeast Asia, water hyacinths are composted for 
use as food supplements for carp and tilapia, suggesting that they might be useful as a food supplement for crawfish. The University of Southwestern Louisiana is proposing to use a symbiotic greenhouse aquaculture unit to determine the cost effectiveness of using geothermal heat for nursery production of exotic tropical species and to generate water hyacinths for composting and use as crawfish food supplements (Huner and others, 1990).

\section{Processing}

Temperatures available in geopressured resources are generally adequate for food and grain processing, and packaging. Specific applications are determined by market needs, the types of food and grains available, and transportation economics. Cooling needs can be met by using refrigeration units that use energy from the hot geothermal fluids, or from gas-fired units using gas that is available in the geopressured resource. The refrigeration units can also be driven with electricity from a binary cycle generator installed at a geopressured facility.

Agricultural crops and fish processing have high potentials for development in areas where potential geopressured resources are located. Agro-flex is investigating various applications for use in the 13 parishes in Louisiana that the organization represents. Installing facilities to process products resulting from an integrated geopressured facility could prove to be an economical adjunct. 



\section{ECONOMIC CONSIDERATIONS}

This section includes a discussion of economic considerations for geopressured application. Specific cost information is provided for the areas that appear to have the greatest potential for direct use, such as desalination, an integrated agriculture/aquaculture facility, and gas and brine sales.

\section{GENERAL}

Current economics do not allow a geopressured well to be developed for the exploitation of only natural gas because of the high investment costs and marginal quantity and quality gas produced. However, because of the size of the geopressured reservoir and the presence of hot fluids under high pressures, it is possible that a mix of applications that exploit these resources could prove to be economical. It is the purpose of this economic study to investigate if a cascading of energy applications such as gas sales, desalination of water, and agriculture/aquaculture would be economical from a developers point of view.

Specific market needs in geopressured regions will encourage those applications that will produce the greatest net return and benefits. For example, the lower Rio Grande Valley of Texas and the central valley of California have the concurrent need of potable water and presence of geopressured resources. Site specific desalination and agriculture/aquaculture applications could result in the profitable development of a geopressured resource.

It is essential that all available options are evaluated and balanced to derive optimal scenarios in which the guiding principle is to extract the highest return on investment under the specific constraints that are imposed upon the installation. The use of other energy feedstocks, such as common fossil fuels and other wastes, biomass, etc., should also be considered so that environmental considerations, conservation of energy, and careful design all contribute to a synergy. 
The choice of sites can have a significant impact on the total installed and operating cost of a facility. Soil characteristics, climate, freshwater availability, waste disposal requirements, market accessibility, availability of goods and services, utility requirements and regional sales prices for gas and electricity are but a few of the considerations that affect the selection of a specific site.

Generalized costs have been developed for workover of geopressured wells, a desalination facility, and an agriculture/aquaculture installation, the combination of which appears to possess the greatest potential for near term utilization. Throughout the analyses, conservative values are assigned to all cost and revenue items. Obviously, any one cost assumption cannot address all of the factors appropriate to a site specific location. It is critical that these generalized costs are not given "gospel" status and are presented as conservative analyses for an assumed installation.

The costs associated with the development of any one facility are affected by previous experiences and the interpretation, interpolation, and extrapolation of data for planned installations. Because of the numerous market and resource variables and because an exact duplicate of an existing facility is likely not available, both capital and operating costs are going to be hard to derive by a mere examination of past data. Any responsible application of technologies that exploit the available energy in a geopressured resource will have to be matched by the economic skills of market analysis and product development.

\section{Economic Methodology and Assumptions}

The Present Value (PV) methodology is used to calculate the discounted payback and Net Present Value (NPV) of selling a selected array of products from a geopressured-geothermal resource. Often referred to as a Discounted Cash Flow Analysis (DCFA), PV analysis is an economic method or process of equating all past, present, and future costs and revenues to a common point-of-time value. Analysts generally prefer PV analysis over other economic techniques because cash flows are accounted on a real-time, common 
economic techniques because cash flows are accounted on a real-time, common dollar basis. This common dollar basis is obtained by discounting all after-tax cash values to a PV cash value using a discount rate. This discount rate is a percentage by which future value dollars are reduced year to year to a present value. Because the discount process substantially reduces the PV of projects with economic lives $>5$ a year, selection of a discount rate is a very important consideration. A $15 \%$ discount rate is a commonly accepted discount rate in developing mineral resources while a $26 \%$ discount rate allows for a higher risk typically associated with gas and oil development. Because the cascaded or multi-use of the geopressured-geothermal brine increases the complexity while also diversifying the product mix, a $15 \%$ discount rate was assumed.

Results of this study are presented in a discounted payback and NPV analysis. (The breakeven analysis was not used because of the array of combinations available and assigning market ratios between each product). Discounted payback is defined as the minimum time required for the project to generate enough discounted revenues to equal the initial investment of the project. Investors and lending institutions typically use this method to assess the time to recover their investment. The shorter the payback, the less risky the investment because market conditions are less likely to change in the shorter period of time than in a longer period of time. NPV is another method of analysis that determines the net value added to an investment. As the name implies, the initial investment is subtracted from the present value of operating revenues less costs. Again, investors and lending institutions typically use this method of analysis to assess the overall profitability of a project, selecting the project with the greatest NPV.

\section{DESALINATION ECONOMICS}

There has not been sufficient replication under similar conditions to warrant extrapolation of prior economic data. Regardless of the desalination process, there are a number of variables that will affect the cost of a facility:

1. Quality and quantity of raw geopressured fluid 
2. Temperature of raw geopressured fluid

3. Degree of desalination desired

4. By-products (electricity, chemicals, gas, mixed salts)

5. Spent geopressured fluid disposal

6. Geopressured fluid utilization constraints

7. Piping features

8. Site-specific factors

9. Suppliers of desalination equipment

10. Environmental considerations and constraints.

Experience gained by International Management Services has shown that the production cost of potable water can range from $\$ 8 / 1000$ gal to practically zero, depending upon the particular mix of conditions.

A fundamental consideration in the selection of a desalination process is the required amount of energy to produce desalinated water, i.e., pounds of product water per pound of steam. The relative cost of other energy feedstocks (i.e. natural gas, diesel oil, fuel oil, etc.) that could be used to drive a desalination facility should be considered in the selection process. Current analysis of these tradeoffs indicate that when other products or energies can be produced and marketed from a geopressured resource, the cost of energy for desalination approaches zero; in effect, the sale of water has to recover only the cost of capital equipment and operating costs.

Site selection can have a significant impact on the installed cost and operating expense of a desalination plant. Site-specific constraints, climatology, soil bearing characteristics, and brine disposal all affect the cost. Whether or not a market is available or could be developed is a very important consideration.

The sale of other by-product chemicals, such as bromine, could improve the viability of a desalination plant. For example, the demand for concentrated brines in Mexico is high and steady and can be marketed for $\$ 2 /$ ton. Vulcan Chemicals also quoted the cost for $\mathrm{NaCl}$ saturated brine in the Hutchinson-Wichita, KS area as $\$ 2 /$ ton. 
Assuming a geopressured well can produce 20,000 bpd of fluid $0300^{\circ} \mathrm{F}$ and for 10 years, desalination of geopressured brine integrated with the production of methane gas is an economically viable investment in a water starved region. Assuming a 15\% discount, payback will occur in 4.3 years and have a NPV is $\$ 4,355,000$ in 10 years. If the bottled water facility is not included, the discounted payback period is 8.2 a year with a NPV of $\$ 546,633$ (Figure 11). This analysis shows the significant impact of using a bottled water facility to greatly increase revenues.

Adding a binary power generator and selling electricity at 6 cents/kWh and selling gas and bulk and bottled water will result in a discounted payback period of 6.2 a year and a NPV of over $\$ 2,862,000$.

\section{Agriculture/Aquaculture Economics}

Based on the data assumed for a typical geopressured we11, the potential is marginal for development of agriculture and aquaculture in most instances a) though feasible in site specific areas primarily targeted for a high value added product. Economic analysis is based on the following well conditions:

- $\mathrm{Flow}=580 \mathrm{gpm}(20,000 \mathrm{bpd})$

- Temperature $=290^{\circ} \mathrm{F}$

- Total chlorides $=72,000 \mathrm{mg} / \mathrm{L}(\mathrm{ppm})$

- Location = Pleasant Bayou, TX

- The geopressured fluid is cooled to $-250^{\circ} \mathrm{F}$ as it passes through a binary power generator before it is made available for the greenhouse facility.

There are many possible combinations in which a facility can be developed; each approach will alter the project costs and profitability. Because this industry is in a development stage and immature financially, it is most likely that a facility would be installed in phases as markets develop. Phased development would require a lower initial capital requirement. Accordingly, the analysis developed costs for the first phase of a multi-phase greenhouse and aquaculture facility. Phase 1 of this installation would include three fiberglass covered greenhouses, each $42 \times 348 \mathrm{ft}$. A fiberglass covered cooling pad house $21 \times 348 \mathrm{ft}$ would be attached to one side wall. The cooling 
pad house would not be heated. A $84 \times 50 \mathrm{ft}$, sheet metal covered service building is included. Following the agriculture application, an aquaculture facility would be an enclosed $36 \times 96 \mathrm{ft}$ fiberglass "greenhouse" which would house three $20 \mathrm{ft}$ diameter aquaculture tanks. Following the aquaculture facility, would be an $8 \times 45 \mathrm{ft}$ outdoor recirculating raceway tank. Figures 10 and 11 illustrate the heat exchanger arrangement for the Phase 1 installation.

Eight phases of future expansion could result in 8 acres of greenhouses, and 2.8 acres of recirculating aquaculture raceways or 3.2 surface acres of flow-through raceways. Figure 12 depicts a possible eight phase installation with one aquaculture facility. The aquaculture facility could be repeated for each phase of greenhouses, if so desired.

Phase 1 cost estimates (Table 3) for installed greenhouses are from Campbell Glasshouses, Inc. Greenhouse structure costs will vary by location. The geothermal heating systems components are estimated from aquaculture systems costs provided by Red Ewald, Inc. (Appendix $C$ ). These costs are provided for rigid wall type structures and are not used for the economic analysis given later in this study. Data used in the economic analysis are from the Comparative Performance Analysis prepared by Southwest Technology Development Institute. 
Table 3. Agriculture/aquaculture first Phase Cost Estimate

\begin{tabular}{lr}
\hline Greenhouse/Pad House (51,156 $\left.\mathrm{ft}^{2}\right)$ & $\$ 352,600$ \\
Service Building (4,200 $\left.\mathrm{ft}^{2}\right)$ & 43,300 \\
Mechanical Equipment (Heat exchanger, etc.) & 11,900 \\
Aquaculture Enclosed Facility & 90,700 \\
Aquaculture Outdoor Raceway & 16,300 \\
15\% Overhead and Profit & 77,000 \\
$20 \%$ Cont ingency & 102,700 \\
TOTAL & $\$ 694,500$
\end{tabular}

Note: Well development costs are addressed separately 


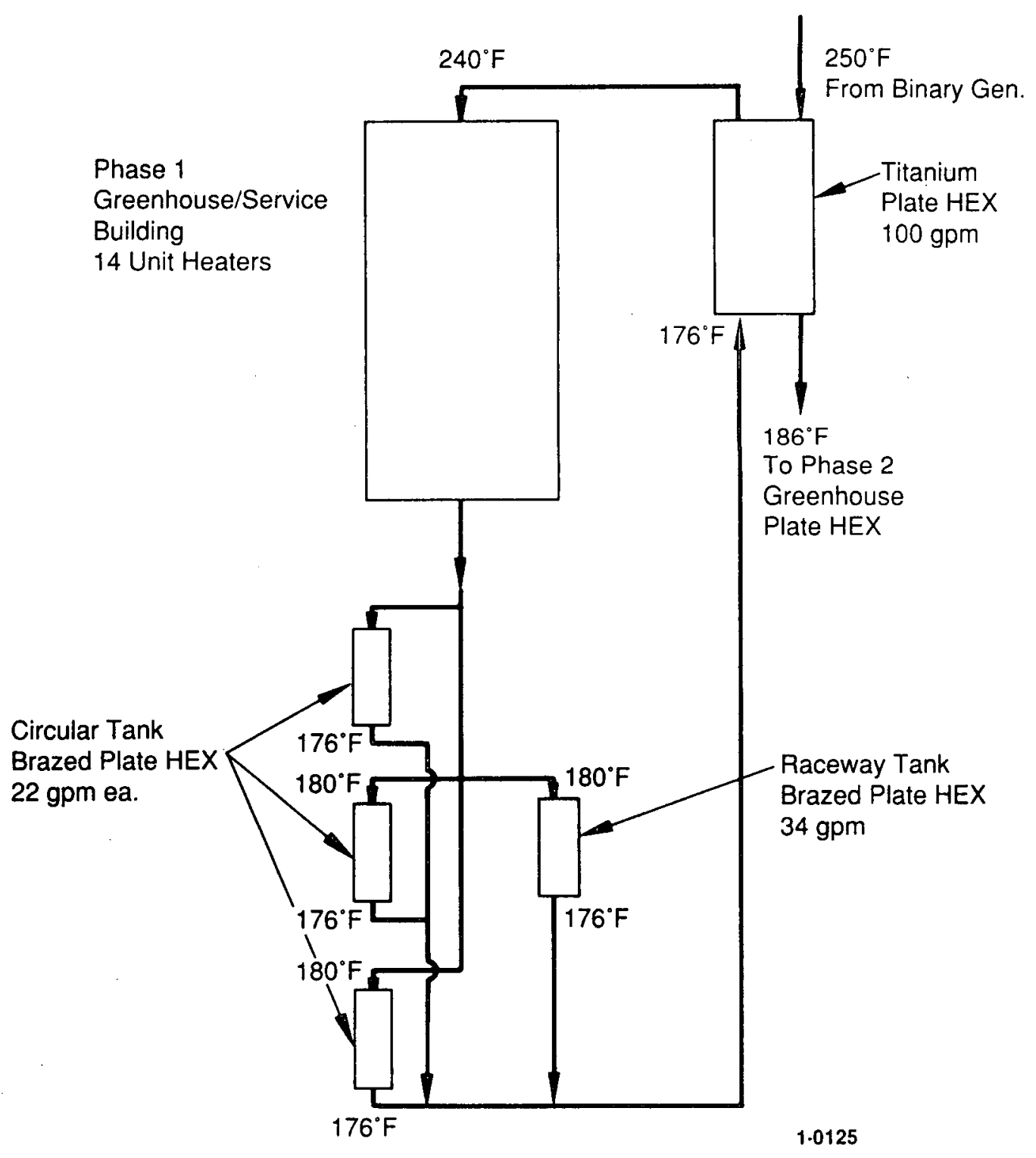

Figure 10. Process flow diagram for phase 1 greenhouse/aquaculture complex. 


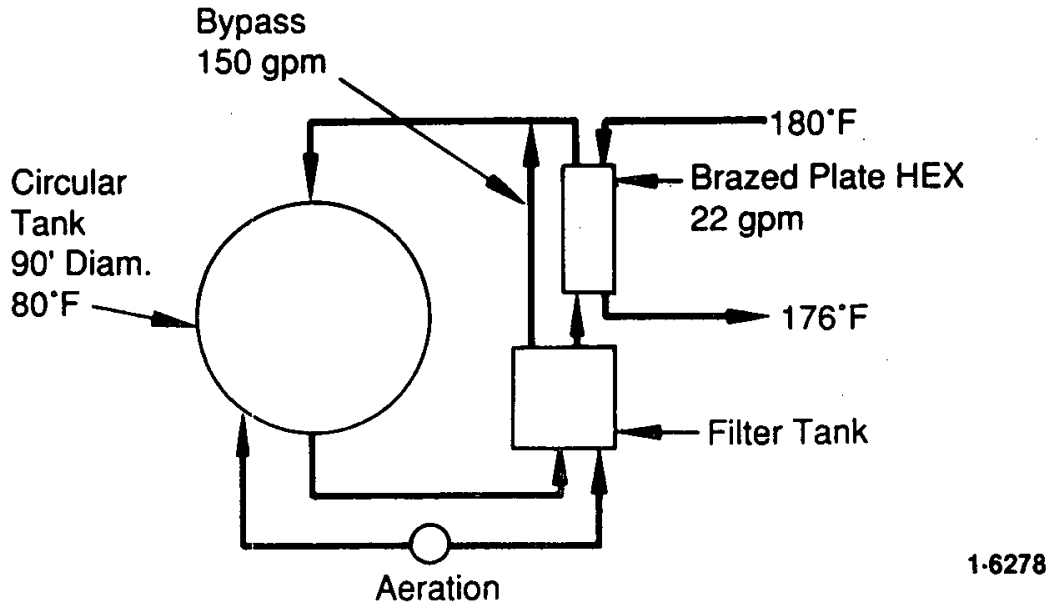

Figure 11. Aquaculture high density recirculation system. 


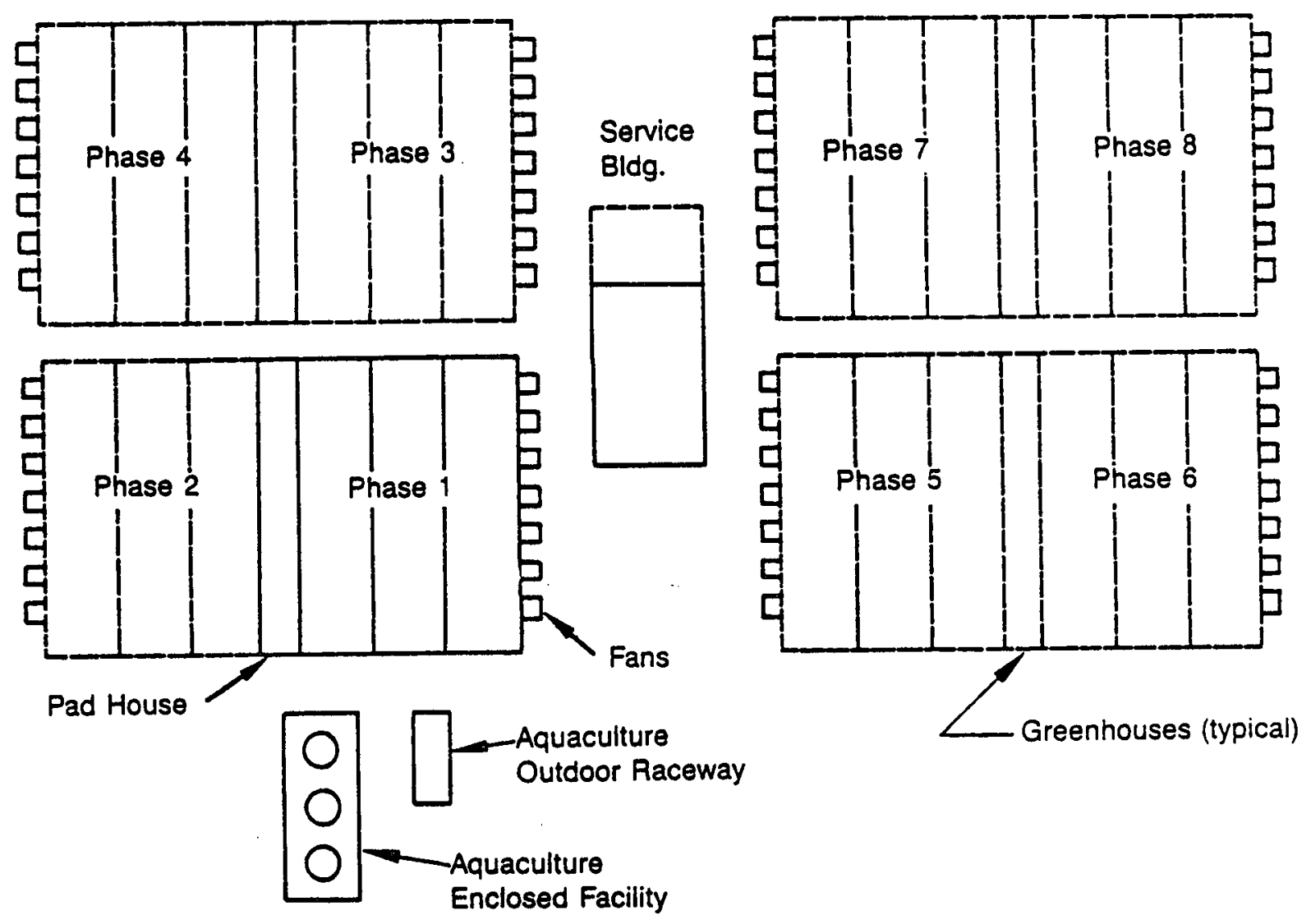

0.8055

Figure 12. Potential greenhouse/aquaculture complex. 
Potable water for agriculture and aquaculture needs could be obtained from surface water sources, wells, or through desalination using the geopressured fluids. Costs related to surface water usage are normally considered relatively minor. Desalination costs are addressed in a previous section. A freshwater well and 10,000 gal storage tank would cost $-\$ 46,000$.

The Southwest Technology Development Institute, New Mexico State University at Las Cruces, New Mexico continues to be extensively involved in the utilization of geothermal resources, especially for greenhouses. The following information is from comparative performance analyses that were prepared by Whittier and Fischer (1990).

Profitability of a greenhouse operation varies for each site, but is directly attributable to one major operating factor that controls the industry: greenhouse space represents a fixed production area. There are few options within reason, to increase annual production from the greenhouse. Because production is fixed, annual revenue is similarly fixed. Opportunities for increasing profitability come from lowering operating costs (Whittier and Fischer, 1990, Appendix F). Using the energy available in geopressured resources may become a means toward this end.

There are many factors that affect the profitability of greenhousing. Capital costs for an installed greenhouse complex vary by location, depending upon such factors as the amount of available sunlight, heating and cooling needs, etc. The amount of available sunlight also affects production levels, especially for cut flowers. State corporate franchise tax rates, variations in Workers' Compensation rates in different states, local labor wage rates, transportation rates, labor availability, property tax rates, cost of energy, water requirements, and market availability also impact the profit margin. A new firm will wish to carefully evaluate individual sites on a case-by-case basis before selecting a location (Whittier and Fischer, 1990, Appendix F).

A comparative performance analysis (Whittier and Fischer, 1990, Appendix F). has been conducted to examine the various factors associated with establishing and operating a commercial rose cut-flower greenhouse in ten 
different locations across the United States. Plant productivity, defined as net blooms produced per plant per year, is largely dependent upon local climatic conditions and technological improvements. Regional variations in productivity have been explicitly analyzed. The greenhouse operation is assumed to be four acres in size and the facilities utilize current technologies. The operation is designed as a professionally organized company with an owner/manager, grower, and salesperson. The primary product is a red hybrid tea rose for the wholesale market, generally located in large metropolitan areas. The analysis strongly indicates that new installations for cut-flower rose production are profitable in several areas in the southwest U.S., particularly in New Mexico, Arizona, and Texas. No one area stands out as a favored location; however, Las Cruces, N.M., has the highest net present value and return on investment of those sites investigated (Whittier and Fischer, 1990, Appendix F).

Based on the pro forma model results for the Las Cruces area, an area that may be more typical of areas in the gulf coast region where geopressured resources exist, a cut-flower rose operation may be established and operated in a southwest location at a profitable level. Because of lower real estate prices and the lack of high intensity discharge lighting in the southwest, less capital is required to start a new greenhouse business. However, this analysis does not factor in the cost of a developing geopressured well as the heat source. If the geopressured facility only sells methane and the agriculture/aquaculture products, adding the well results in a $15 \%$ discounted payback period of slightly over 10 years. Because of the marginal economics of this facility, an aquaculture/agriculture facility could be coupled with other uses such as a desalination facility to be more profitable. When the facility includes methane, desalinated water, bottled water, salt, and agriculture/aquaculture products, the discounted payback period is reduced to 4 years, with a 10 years NPV of about $\$ 6$ million. The addition of electricity generation with a methane agriculture/aquaculture facility significantly increases the discounted payback period to over 10 years, when the power is sold at 6 cents/kWh. 


\section{Desalination/Agriculture/Aquaculture Economic Results}

The study included one more analysis, a geothermal turbine unit was installed with desalination and an agriculture/aquaculture facility, taking advantage of the cascading energy values. Results suggest that this scenario becomes profitable only where the market price for electricity exceeds 5 cents/kWH. Currently, many areas of the country that have geopressured resources also have a surplus electrical capacity and generation, thus power utilities have been offering less than 2 cents per kWH, well below the reasonable breakeven value of 5 cents per KWH. However, when the energy demand of the integrated facility is large enough to install power generation equipment, savings will be obtained by not having to paying the 10 to 12 cents per KWH utility rate.

This study indicates that employment of other direct use technologies, specifically desalinated water production, can contribute significantly to the value added process and the overall economic viability in developing a geopressured resource. Additionally, al though agriculture and aquaculture applications are marginal projects when they are the only application with a geopressure well, the small margin of profitability can contribute to improving the overall economics of additional direct use developments. The added complexity will have to be balanced with the increased technical and management complexity and may add to the overall risk and unpredictability of the project. 
Table 4. Discounted payback periods for various geopressured integrated facilities.

Facility Type

Methane gas/brine salts/bulk and bottled water/agriculture/aquaculture

Methane gas/brine salts/bulk and bottled water

Electricity 06 cents/kWh/methane gas/bulk and bottled water

Methane gas/brine salts/bulk water

Methane gas/agriculture/aquaculture

Electricity 0 cents/kWh/methane gas/agriculture/aquaculture
15\% Discounted

Payback Period (y)

4.0

4.3

6.2

8.2

$>10.0$

$>10.0$
10 y NPV

$(\$)$

$$
5,800
$$

$4,355,000$

$2,862,600$

546,600

$(19,000)$

$(1,511,400)$

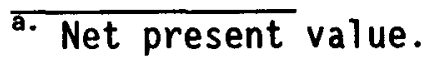




\section{REFERENCES}

Carlson, R. A., P. H. Powell, and G. K. Underhill, 1976, "Industrial Utilization of Geopressured-Geothermal Energy," Second Geopressured-Geothermal Energy Conference, Surface Technology and Resource Utilization, February 23-25, 1976, Volume IV, pp. $146-168,176-179$.

Conner, J. A. and C. J. Newe11, 1990, "Pilot Study for Recovery of Non-Aqueous Phase Liquids (DNAPL) at a Superfund Site and Evaluation of Geopressured-Geothermal Brine as a Potential Remediation 39 Technology," Industrial Consortium for the Utilization of the Geopressured-Geothermal Resources Proceedings, January 10, 1990, Rice University, Houston, Texas, Volume 2, March, 1990, pp. 57-76.

Darling, P., 1989, "Scalding Sulphur From the Gulf," International Mining, October 1989, pp. $22-27$.

Dorfman, M. H. and R. A. Morton, 1985, "Geopressured Geothermal Energy," Proceedings of the Sixth U.S. Gulf Coast Geopressured-Geothermal Energy Conference, Pergamen Press, N.Y., 1985, pp. 344.

Eckert, Jr., G. F., 1987, "Frasch Sulphur Production Trends Favor Mines Outside North America," Engineering and Mining Journal, December, 1987, pp. 46-51.

Hornburg, C. D., 1975, "Geothermal Resource Utilization - Paper and Cane Sugar Industries," Proceedings, First Geopressured Geothermal Energy Conference Center for Energy Studies, University of Texas at Austin, June 2-4, 1975, p. 238.

Huner, J., L. F. Fall, D. L. Wollard, E. A. Cazayoux, S. Belanger, J. K. Saichuk, M. Richard, and J. Island, 1990, "Applications of Geothermal Waste Heat To Aquaculture and Agriculture," Proceedings of the First Industrial Consortium for Utilization of Geopressured-Geothermal Resources, January 10, 1990, Rice

University, Houston, Texas, Volume 1, March, 1990, pp. 77-88.

Lienau, P. J., 1990, "Direct Heat," Geothermal Resources Council Introduction to Geothermal Resources, March, 1990, 1, pp. 3-4.

Lienau, P. J., 1989, "Industrial Applications" Geothermal Direct-Use Engineering and Guidebook, Geo-Heat Center, Oregon Institute of Technology, Klamath Falls, Oregon, March, 1989, p. 297.

Lund, J. W., 1987, "Cascading of Geothermal Energy in Italy," Geo-Heat Center Quarterly Bulletin, Summer 1987, pp. 13-16.

Lunis, B. C. and P. J. Lienau, 1988, "Status and Trends of Geothermal Direct Use Projects of the United States," Geothermal Resource Council Transactions, 1988 Annual Meeting, Volume 12, pp. 15-19.

Muffler, J. P., Editor, 1979, Assessment of Geothermal Resource of the United States - 1978, Geological Survey Circular 790, 1979, pp. 132-153 and 159-160. 
Negus-de Wys, J., 1990, "The Geopressured-Geothermal Resource: Transition to Commercialization," Proceedings of the First Industrial Consortium for the Utilization of the Geopressured-Geothermal Resource, Proceedings, January 10, 1990, Rice University, Houston, Texas, Vol. 1, March, 1990, pp. 11-15.

Negus-de Wys, J., 1989, "Properties of Geopressured Brines and Wells in the Gulf Coast and Opportunities for Industrial Research/Participation, "Proceedings of the Geothermal Program Review VII, March 21-23, 1989.

Nitschke, G. S. and J. A. Harris, 1990, "Production of Fresh Water and Power from Geopressured-Geothermal Reservoirs," Proceedings of the First Industrial Consortium for the Utilization of the Geopressured-Geothermal Resource, Proceedings, January 10, 1990, Rice University, Houston, Texas, Vol. 1, March, 1990, pp. 89-105.

Rafferty, K., 1990, "Heating Requirements for Thermal Refuge Areas," Oregon Institute of Technology Geo-Heat Center, Memorandum to Interested Texas Aquaculture Association Members, February, 1990.

Ray, L. E., 1990, private communication, Fish Breeders of Idaho, Inc. January 3, 1990.

Rofer, C. K., 1990, "Destruction of Hazardous Wastes by Supercritical Water Oxidation," Proceedings of the First Industrial Consortium for Utilization of Geopressured-Geothermal Resources, January 10, 1990, Rice University, Houston, Texas, Volume 2, March, 1990, pp. 77-103.

Spencer, F. J., 1990, "The Economic Impact of Geopressured/Geothermal Resource Development," Proceedings of the First Industrial Consortium for Utilization of Geopressured-Geothermal Resources, January 10, 1990, Rice University, Houston, Texas, Volume 1, March, 1990 pp. 109-113.

Tikhonov, A. N., P. F. Shvertsov, I. M. Dvorov, 1990, "Research and Utilization of Geothermal Energy in the USSR," Geothermal Resources Council Bulletin Volume 15, No. 8 , August 1986, p. 7 .

Whittier, J. and C. L. Fischer, 1990, "Comparative Performance Analysis: Commercial Cut-Flower Rose Production," Southwest Technology Development Institute, New Mexico State University, Las Cruces, NM, Apri1 1990.

Wright, P.M. and G. Culver, 1989, "Nature of Geothermal Resources," in Geothermal Direct Use Engineering and Design Guidebook, P. J. Lienau and B. C. Lunis, Geo-Heat Center Oregon Institute of Technology, Klamath Falls, Oregon, March 1989, p. 35. 


\section{APPENDIX A \\ SEATTLE TIMES EDITORIAL \\ "CALIFORNIA WON'T FACE WATERING TRUTH \\ MAY 27,1990}

$A-1$ 


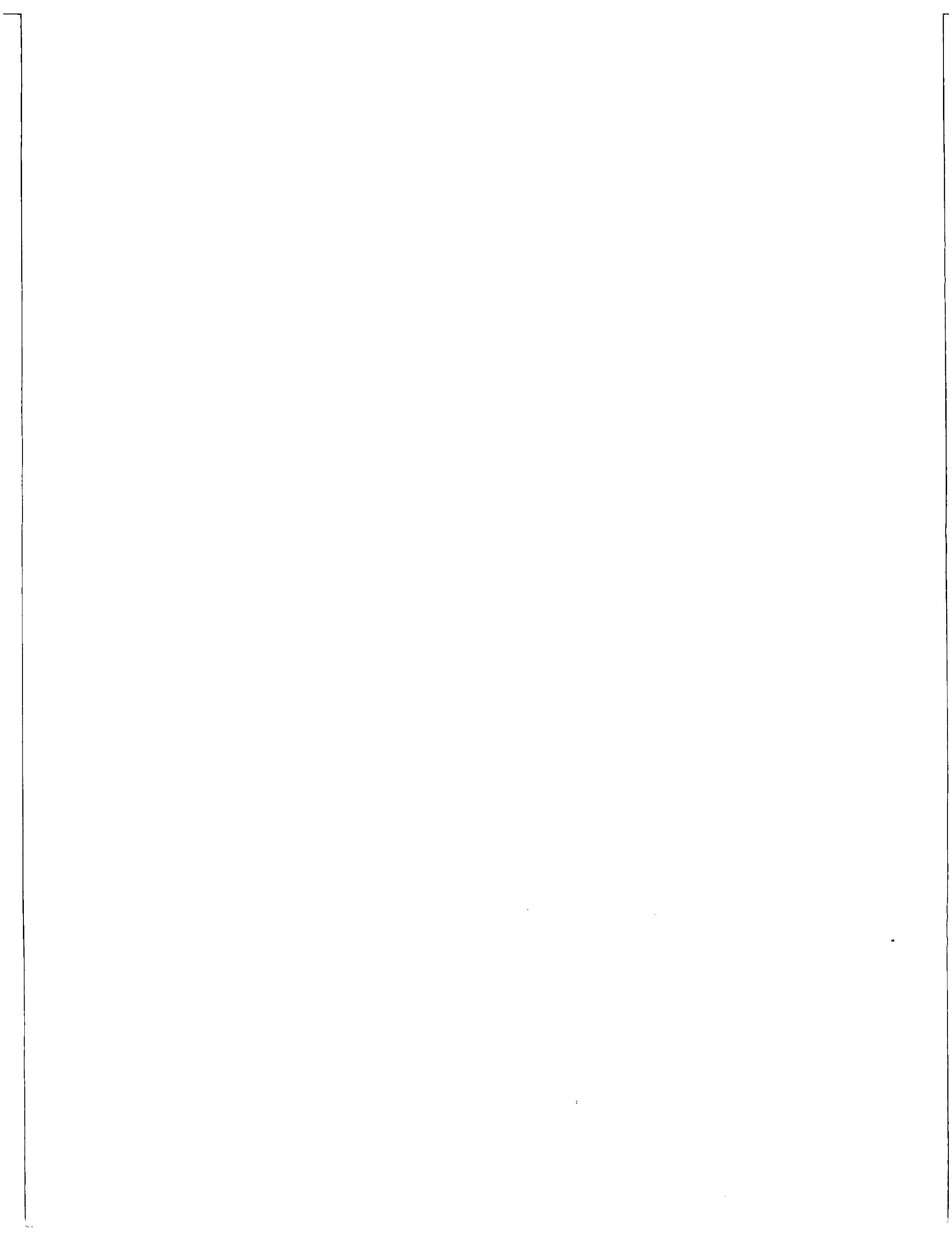




\section{CALIFORNIANS WON'T FACE WATERY TRUTH}

Mindy Cameron

Times editorial page editor

Once upon a time there was a scheme called the North American Water and Power Alliance. NAWAPA was a grandiose plan for rearranging resources, a way to undo Mother Nature's design and better serve a booming population.

The gigant ic water transfer plan was born in the ' 60 s at a Pasadena engineering $f$ irm, Ralph Parsons Co. It was the brainchild of engineers with a can-do bravado second to none.

When I first heard about NAWAPA, I thought it was a joke. It was 1977 . The young vigorous environmental movement was gaining momentum, so much so that President Carter had dared to propose major reforms of water use and scrapping 19 water-development projects. Surely in this new age no one was seriously contemplating such a colossal transfer of water?

But it was no joke to the folks at Parsons. Then, as now, Southern California was in the midst of a drought. Many experts were trying to solve the puzzle of the region's perpetual water shortage.

Ralph Parsons Co. was touting NAWAPA as the answer. A promotional film explained the scheme. Water, a solemn voice proclaimed "is a continental problem which requires a solution that is also continental."

This was serious stuff. As the graphics unfolded on the screen, showing waterways snaking down the continent from Alaska, through Canada, the Northwest, the voice described the awesome proportions of the plan: larger than the Alaska pipeline; $\$ 200$ billion hundreds of dams; huge tunnels through mountains; canals hundreds of feet wide.

NAWAPA lives on in the mid of Los Angeles County Supervisor Kenneth Hahn who this month persuaded his colleagues to back his proposal to divert water from the Columbia and Snake Rivers to Southern California.

Sure, it's a nutty idea to those of us who are accustomed to having rivers do most of their work within the ir banks.

But water and rivers have a different meaning to some Southern Californians.

Life there depends on imported water. Los Angeles survives -and thrives - thanks to the world's largest water transfer system. The longest of the three watery lifelines is a 444-mile, man-made river system. It even defies gravity. Fourteen pumps lift water nearly 2.000 feet over the Tehachapi Mountains north of Los Ange les.

Unfortunately, the great effort by which this water is provided has not fostered greater appreciation by users. To the contrary.

Agriculture accounts for 85 percent for all the water used in California. Much of it is squandered by farms, including many huge agriculture conglomerates, whose water rates are kept low through federally subsidized irrigation projects of the 8 ureau of Reclamation. There is little incentive to switch from wasteful flood irrigation practices to drip or other, more conservative methods of crop irrigation. Domestic use is much the same story. The few communities not tied to the state's huge water system are notable exceptions. Marin County for example, has had water-conservation requirments in place for years. The latest dry cycle is forcing water rationing on other communities.

But despite the clear warning signs of the late' 70 s. Southern California has refused to come to grips with its most basic reality. It is a desert region of severely limited water resources. In direct definance of that reality, lush new suburbs, often, surrounding man-made lakes, continue to crop up in the arid hills farther and farther from Los Angeles.

California bashing is a favorite Northwest pastime right now. There's plenty of evidence to suggest they don't deserve the blame we have so gleefully laid at their doorstep Californians aren't responsible for our crowded freeways, our spiraling housing costs, our dwindling open spaces.

But now the folks who run Los Angeles County have fired what they call "a shot in the dark." Kenneth Han's proposal would have the governors of seven Western states and President Bush respond to the latest drought cycle in Southern California by ordering the U.S. Corps of Engineers to design and build the aqueducts to transfer water from the Northwest to Southern California.

It won't happen of course But all of a sudden Hahn's shot in the dark gives substance to what until now has been a frivolous exercise.

Fire away Bash at will Californians who persist in the notion that their playground is the center of the universe are an easy and deserving target. Why in the world should the rest of us serve up our precious resources to keep their desert blooming?

Mindy Camerons column appears Sunday on The Times editorial page. 


\section{APPENDIX B}

HEATING REQUIREMENTS FOR THERMAL REFUGE AREAS

(K. RAFFERTY, OREGON INSTITUTE OF TECHNOLOGY GEO-HAT CENTER)

B-1 


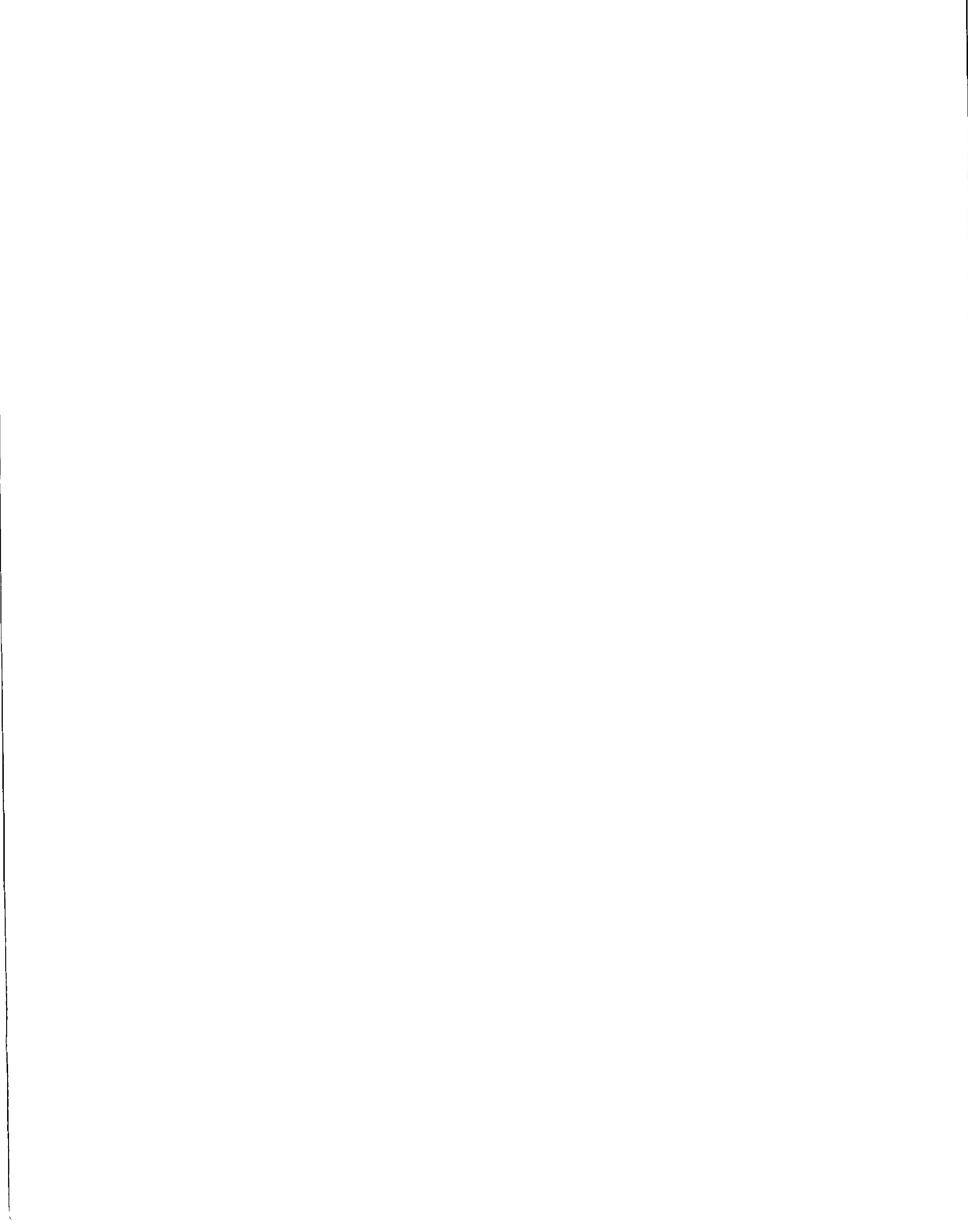


DeTE:

February 19, 1990

0 :

Interested TAA Memiers

SZON:

Kevin Rafferty, Geo-Heat Center

SUBJECT: Heating Requirements for Thermal Refuge Areas

Following this year's Texas Aquaculture Association meeting and field trip, I had the opportunity to meet with several of the commercial growers and tour their facilities (including: Redfish unlimited, Southwest Mariculture and Sealantic Inc.). Much of the discussion on the field trip and in subsequent meetings focused on the issue "thermal refuges" to shelter the fish during extreme winter conditions.

The design for a refuge which seemed acceptable for most operators involves an arrangement modeled after that used successfuliy by Richie Farms this winter. In this case a cover was suspended by cables over a corner of the pond forming a triangular sheltered area. The cover was installed approximately level with the pond banks (only a foot or two off the water). On the side facing the pond, the cover was extended underwater and weighted in order to form a wall between the refuge and the open pond. A space was left between the cover and the bottom of the pond for fish passage.

Richie Farms had the advantage of using an $86^{\circ} \mathrm{F}$ well to provide heat for their thermal shelter. For most other operators, some other source (boilers, etc.) would be required to provide the heat input. The enclosed curves were developed to assist in heater sizing.

Three curves are provided, one each for $50^{\circ}, 60^{\circ}$ and $70^{\circ} \mathrm{F}$ pond water. This temperature refers to the value which would apply to the water under the cover. Three types of lines appear on each graph. The lines sloping from lower left to upper right correspond to outside air temperature and represent the heat loss through the cover (from the air under the cover to the outside air). The lower curve, sloping from the upper left to the lower right represents the heat gain from the pond surface to the air under the cover. The upper curve sloping from upper left to lower right is a plot of the required heat input to the water. To use the graphs, first select the graph associated with the minimum temperature which you wish to maintain in the refuge $\left(50^{\circ}, 60^{\circ}\right.$ or $\left.70^{\circ} \mathrm{F}\right)$. Using the minimum outside temperature which you feel appropriate to your location, find the intersection between the curve for that 
temperature and the heat gain curve. Proceed vertically to the intersection with the heat input curve. From the intersection proceed horizontally to the $y$-axis to read the heat input requirement in Btu/hr per square foot of sheltered pond surface.

The following example (see $60^{\circ} \mathrm{graph}$ ) illustrates the use of the graphs. Assume that a grower wishes to cover 5,000 $\mathrm{ft}^{2}$ of pond and maintain $60^{\circ} \mathrm{F}$ in the refuge area. The location is such that $20^{\circ}$ can be safely used for the design outside temperature. Based on these factors, the heating requirement for the refuge would amount to 72 Btu/hr per square foot of pond surface under the cover. The total requirement for $5,000 \mathrm{ft}^{2}$ would be $5,000 \mathrm{ft}^{2} \times 72 \mathrm{Btu} / \mathrm{hr} \cdot \mathrm{ft}^{2}=$ 360,000 Btu/hr. As a result, the heater selected for this application should be capable of a minimum of 360,000 Btu/hr output.

I must stress that the values used to develop these graphs are calculated heat losses. I have no direct experience with this type of cover to use as verification of the calculations. As a result, I have used a conservative approach to develop the numbers.

There are two considerations with regard to the use of this type of thermal refuge which warrant emphasis.

1. When installing the cover, it is most important to keep it above the water. Once the cover is permitted to rest on the surface of the water, its effectiveness is severely compromised. You may wish to consider using "floats" of some sort (styrofoam, tire tubes, etc.) to prevent the cover from falling onto the pond surface.

2. It is important to anticipate the need for the thermal refuge and begin adding heat as far in advance of need as possible. The heat loss values which appear in the graphs assume that the water under the shelter is already at the required temperature. Heating input necessary to bring the water up from a lower temperature can be significant. Using the example pond, and assuming an average depth of $4 \mathrm{ft}$, a total of 150,000 galions would be contained under the cover $(5,000$ $\mathrm{ft}^{2}$ ). To heat this water from $50^{\circ}$ to $60^{\circ}$ would require a total of $12,500,000$ Btu or 35 hours of continuous operation at full heater capacity. If it will be necessary to bring the refuge temperature up to the desired value (from a lower temperature), this heaing load should be the basis for heater sizing rather than the steady state approach outlined above. 


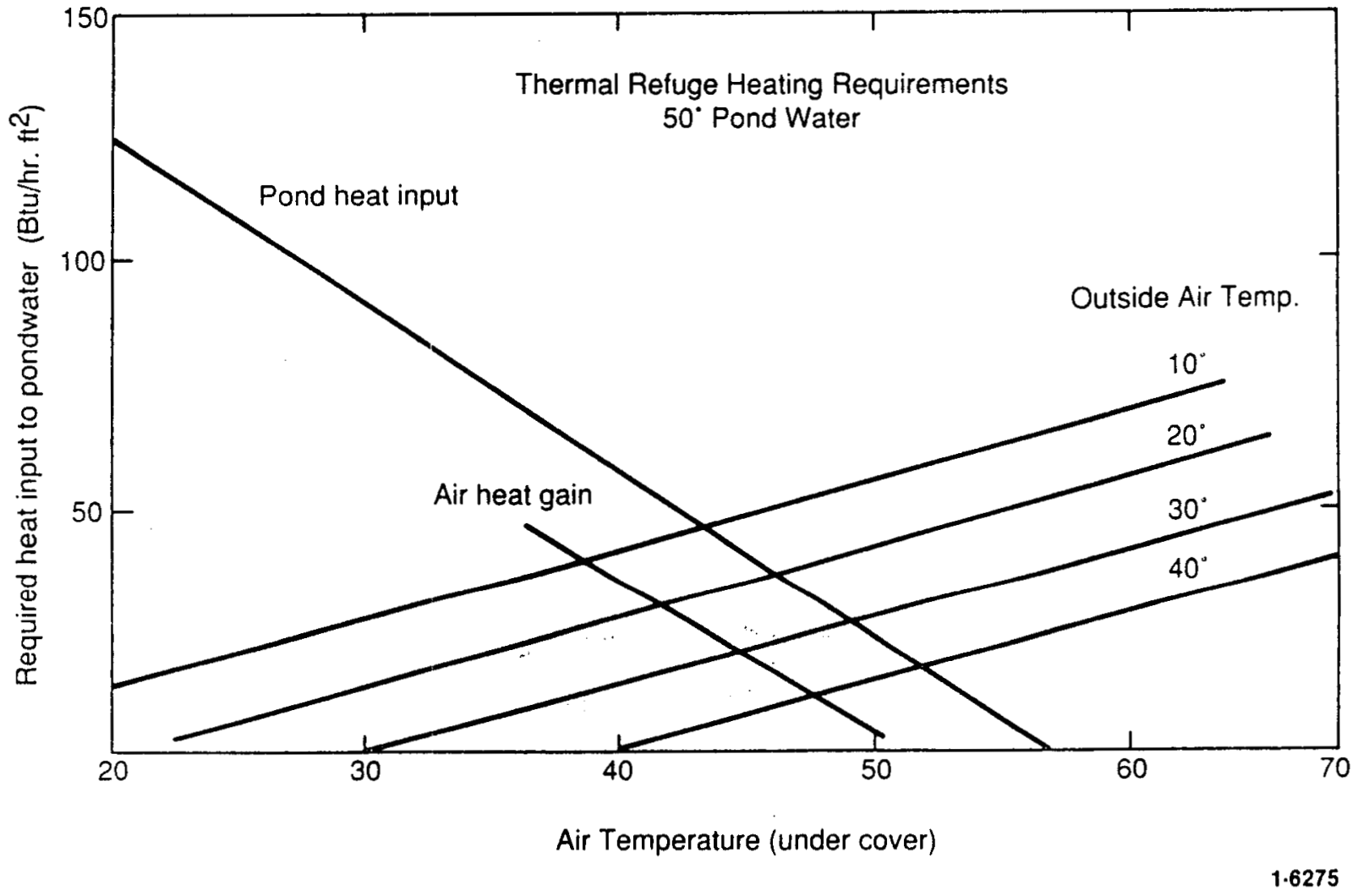




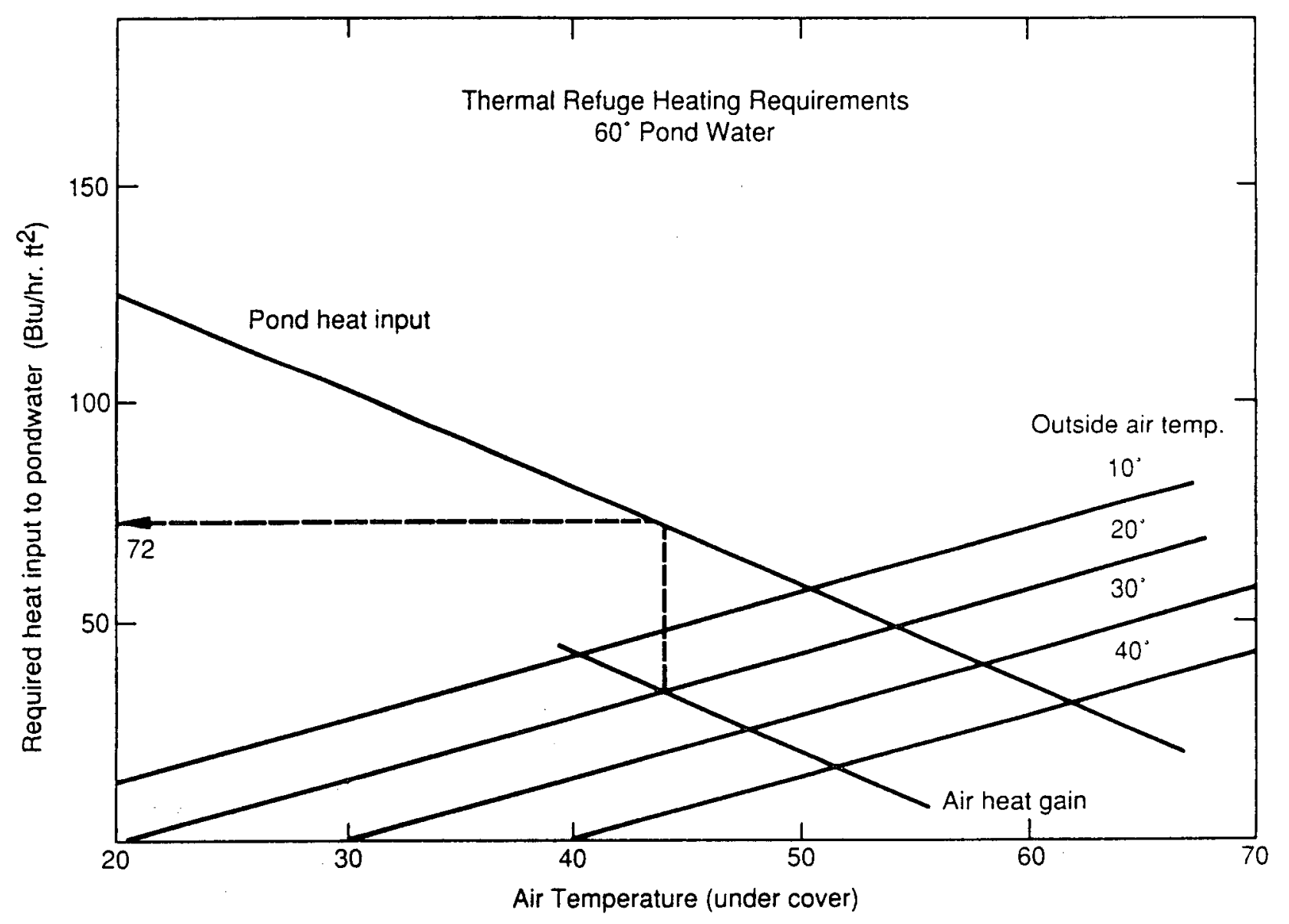

1.6274 


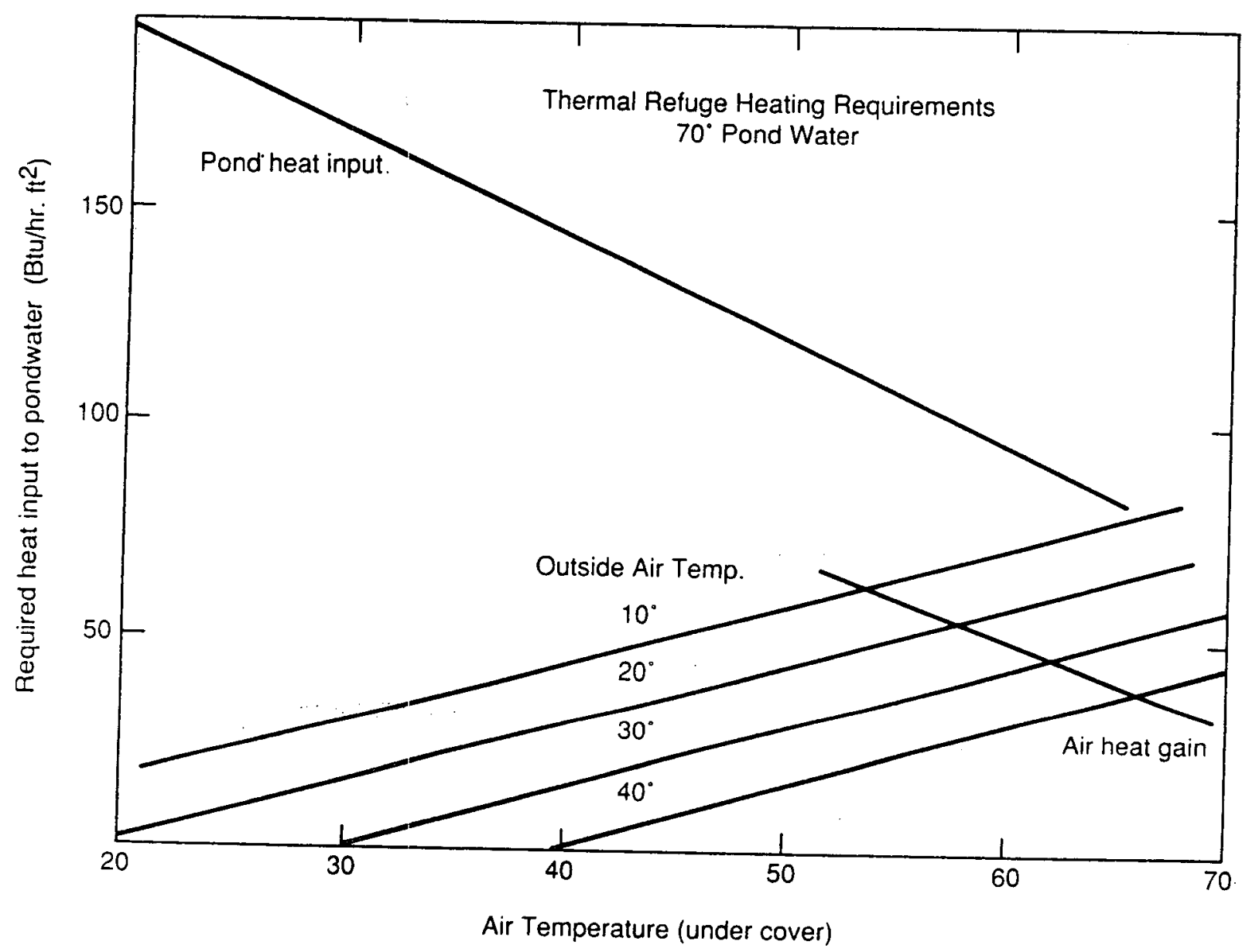

1.6276 


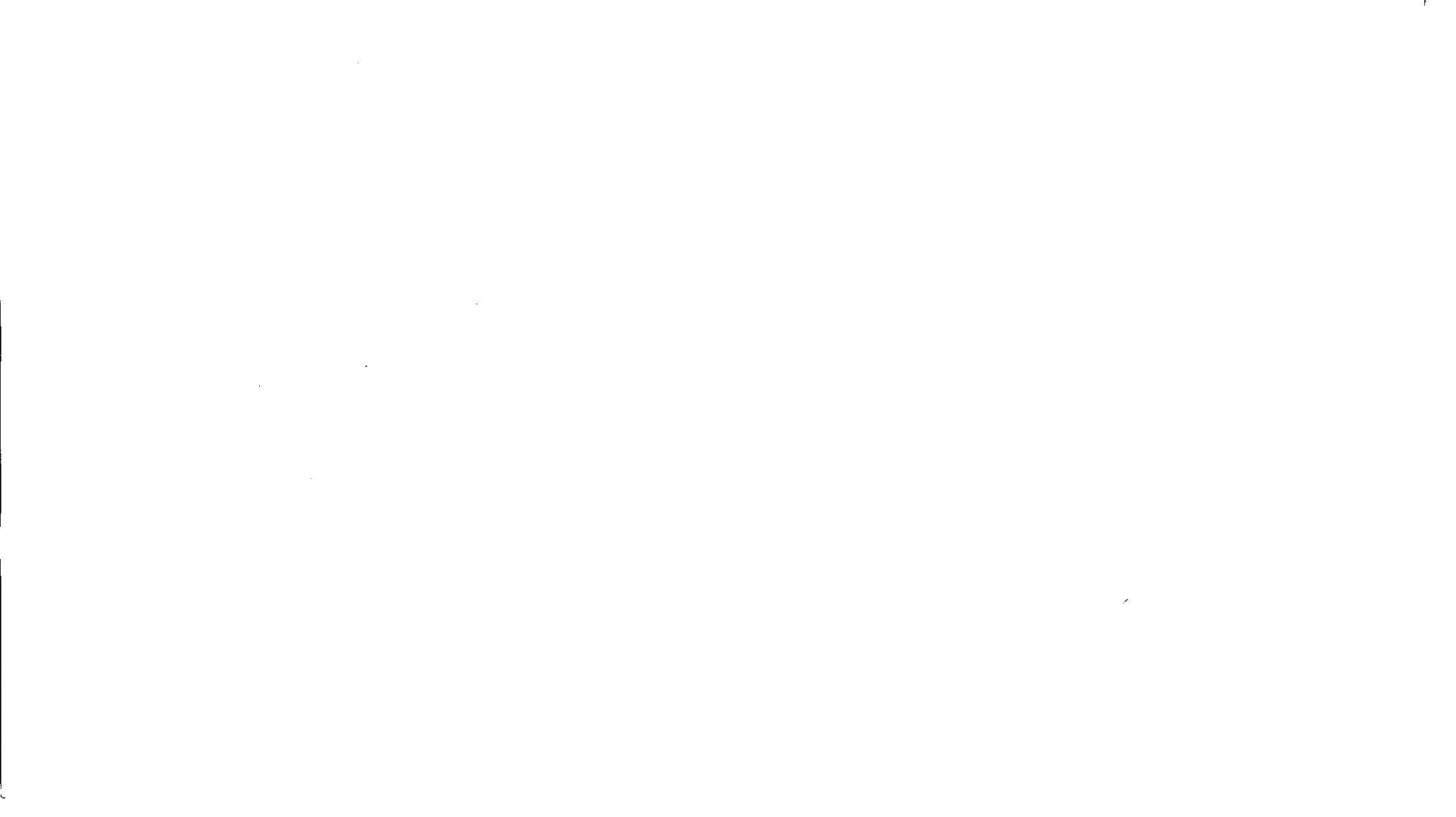


APPENDIX C

INTEGRATED APPLICATIONS ECONOMIC ANALYSES

C-1 


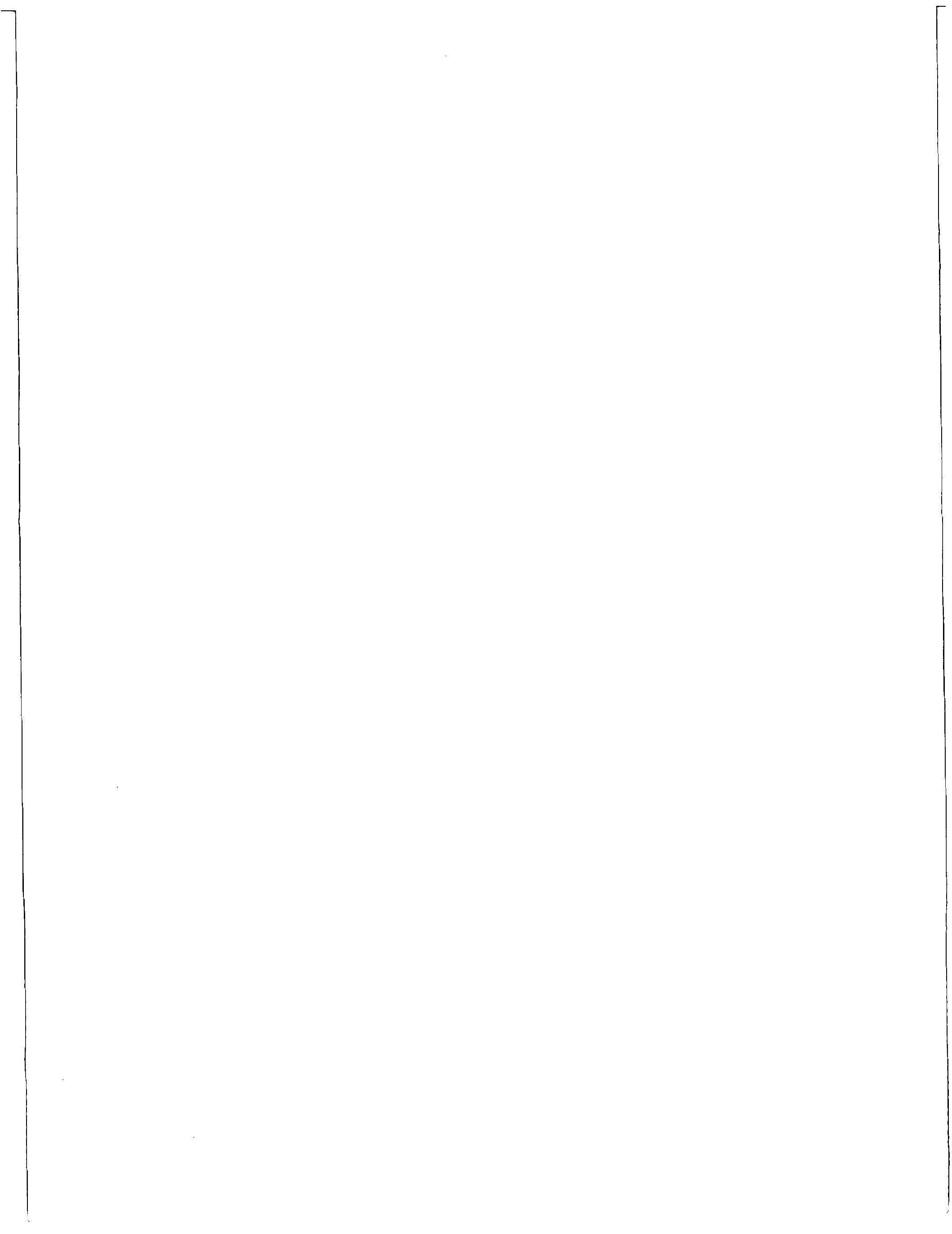


ANALYSIS OF WELL: Large Volume, Moderate Temp. Geopressured-Geothermal Well

MOOEL ANALYSIS: Methane/Saits/Buik \& Bottled Water/Agri \& Aqua Products

RESULTS :

$$
\begin{array}{lr}
10-Y R \text { MPV } & 55.957 .976 \\
\text { Discounted payback } & 4.0 \text { years }
\end{array}
$$

BASE YEAR and CONTRACT OOLLARS : 1991

FINANCIAL SUMMARY:

$\begin{array}{lr}\text { Borrowed } & 2.469 .390 \\ \text { Owners Equity } & 4.391 .310 \\ \text { Capitalized Interest } & 135.816\end{array}$

INVESTMENTS/EXPENSES/REVENUES :

TOTAL PRE-OPERATION/OEVELOPMENT/CAPITAL COSTS

Geopress-Geothermal Heil $2,199,750^{\circ}$

Pipe line Right-of-Way

TOTAL CAPITAL BUILDING/EGUIPMENT COST.

Gas Separator \& Trans

Sulk Water/Salt 1.559 .750

Bottled Water 030.000

Rose/Greenhouse $\quad 887,250$

Fish/Aquaculture $\quad 210.000$

Working Funds $\quad \$ 20,000$

CONTINGENCIES..... .623 .700$

CAPITALIZED INTEREST: . : . . 135.816

\begin{tabular}{|c|c|c|}
\hline$\$ 5,996,516$ & $\begin{array}{l}\text { FIMANCIAL/TAX/ECONOMIC IMPUTS } \\
\text { Oiscount Rate (IRR) } \\
\text { Oebt Rat fo } \\
\text { Interest Rate } \\
\text { Oebt Life } \\
\text { Depreciation Life } \\
\text { Royalty (X of revenue) }\end{array}$ & $\begin{array}{r}15.0 \% \\
40.0 \% \\
11.0 \% \\
3 y \text { yrs } \\
7 y \text { rs } \\
15.0 \%\end{array}$ \\
\hline
\end{tabular}

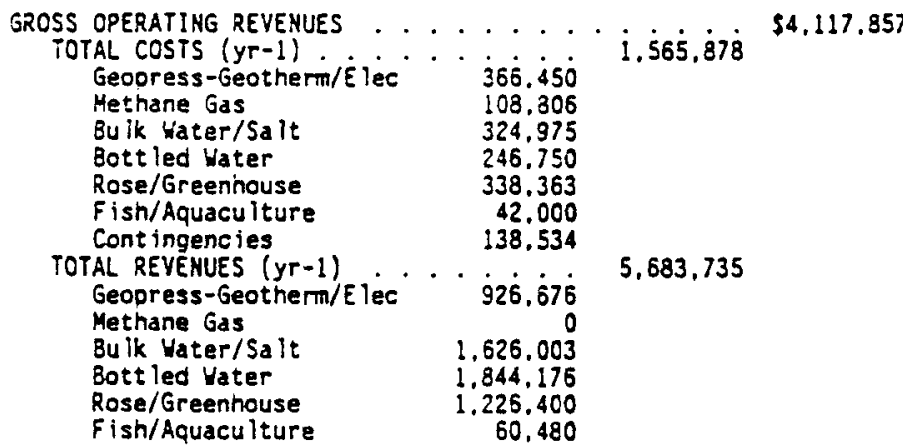

2. 199,750

$\$ 5,996.516$

4.037 .250

Tedera

Federal Tax

State Tax

Severance Tax

Ad Valorem Tax

Inflation Rate

Cost Escalation :

Develooment and Capital Cost op/Post-Op Costs \& Expenses

$38.0 \%$

$2.0 \%$

$5.0 \%$

$7.2 \%$

$5.0 \div$

$0.0=$

Revenue Escalation :

Electricity

Bulk Bottled Water/Saits

Methane Gas

Fish/Aquaculture

Roses/Greenhouse

$0.5 \%$

$1.0 \%$

$0.0 \%$

GEOPRESSUREO-GEOTHERMAL (brine) HELL CHARACTERIST

Well Life

Brine Temo o Surface

Barre is per Day

10 yrs

Gas Concentration / Barrel

Gas Quality

Sottom Hole Pressure

$0.000 \mathrm{BPO}$

Flowing Wellhead Pressure

$80 \mathrm{sci} / 8$

$90 \times$

15.000 psi

2,000 psi

TOTAL POST-OPERATION COSTS ........... . . \$301.346

SALVAGE (at end of project iife) ......... \$o 
ANALYSIS OF WELL: Large Volume, Moderate Temp, Geopressured-Geothermal Well

RESULTS :

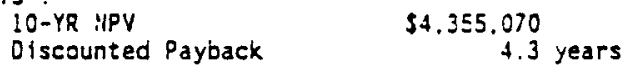

TOTAL PRE-OPERATION/OEYELOPMENT/CAPITAL COSTS . . . \$5,762.988

2.940 .000

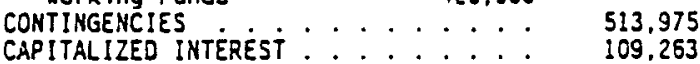

GROSS OPERATING REVENUES ............ \$3,245,176

TOTAL COSTS $(y r-1) \ldots i, 15 i .579$

Geopress-Geotherm/Élec ' $36 \dot{6}$. 450

Methane Gas 108.805

Bulk Water/Sa it 324.975

Bottled Water 246.750

Rose/Greenhouse

Fish/Aquaculture
Cont ingencies
104.698

TOTAL REVENUES $(y r-1) \ldots \ldots$

Geopress-Geotherm/E lec $\cdots+\dot{j} \dot{6} . \dot{6} 7 \dot{5} \quad 4,396.855$

Methane Gas

Bulk Water/Salt $\quad 1.626 .003$

Bottled Water $\quad \lcm{1.844 .176}$

Rose/Greenhouse

Fish/Aquaculture

FINANCIAL/TAX/ECONOMIC IMPUTS :

\begin{tabular}{|c|c|}
\hline $\begin{array}{l}\text { Oiscount Rate (IRR) } \\
\text { Cebt Rat to } \\
\text { Interest Rate } \\
\text { Debt Life } \\
\text { Depreciation Life } \\
\text { Royalty (X of revenue) }\end{array}$ & $\begin{array}{r}15.0 \% \\
40.0 \% \\
11.0 \% \\
3 \mathrm{yr} \\
75.0 \mathrm{yr}\end{array}$ \\
\hline $\begin{array}{l}\text { Taxes: } \\
\text { Federal Tax } \\
\text { State Tax } \\
\text { Severance Tax } \\
\text { Ad Valorem Tax } \\
\text { Inf lation Rate }\end{array}$ & $\begin{aligned} 38.0 & : \\
2.0 & = \\
5.0 & = \\
7.2 & : \\
5.0 & \end{aligned}$ \\
\hline $\begin{array}{l}\text { Deve lopment and Capital Cost } \\
\text { Op/Post-00 Costs \& Expenses } \\
\text { Revenue Escalation: }\end{array}$ & $\begin{array}{l}0.0 \approx \\
0.0 \approx\end{array}$ \\
\hline $\begin{array}{l}\text { Electricity } \\
\text { Bulk \& Bottled Water/Salts } \\
\text { Methane Gas } \\
\text { Fish/Aquaculture } \\
\text { goses/Greenhouse }\end{array}$ & $\begin{array}{l}0.0 \% \\
0.5 \% \\
1.0 \% \\
0.0 \% \\
0.0 \%\end{array}$ \\
\hline
\end{tabular}

GECPRESSUREO-GEOTHERMAL (brine) WELL CHARACTERIST Hell Life

Brine Temo Surface

Barrels per Day

Gas Concentration / Barrei

$300 \mathrm{~F}$

Gas Quality

Botton Hole Pressure

$000 \mathrm{BPO}$

scf/B

Flowing We lihead Pressure

$90 x$

15.000 psi

2.000 psi

5.0

3 yrs

yrs

(2.0

.0

$0 \times$

$0 \%$

$0 \%$

TOTAL POST-OPERATION COSTS ...........

$\$ 301.346$

SALVAGE (at end of project life) ......... so 
ANALYSIS OF VELL: Large Volume, Moderate Temp. Geopressured-Geothermal Well

$08: 39: 18$ AH : time

MODEL ANALYSIS: Electricity@\$0.060/Methane/Bulk 3 bottled Water Products

RESULTS
10-YR NiYY
$\$ 2.862 .583$
Discounted Payback
6.2 years

BASE YEAR and CONTRACT DOLLARS :

1991

FIMANCIAL SUMMARY:

TOTAL PRE-OPERATION/DEVELOPMENT/CAPITAL COSTS . . . \$8.867.466

Borrowed

Owners Equity

Capitalized Interest

3.201 .660

$5,489,715$

176,091

INVESTMEMTS/EXPEMSES/REVEMUES :

TOTAL PRE-OPERATIOM/OEVELOPMENT/CAPITAL COSTS

TOTAL DEVELOPMENT COST Geopress-Geotherma i We il 2 , $199^{\circ}, 750^{\circ}$ Pifeline Right-of - Way

TOTAL CAPITAL GUILDING/EOUIPMENT COST.

Geotherm \& Elec Ea 2.961 .000

Gas Separator \& Irans 120,750

Bulk Water/Salt $\quad 1.569 .750$

Bottled Water

Rose/Greenhouse

Fish/Aquaculiture

630.000

Horking Funds

420,000

CONTIMGEMCIES

$\ldots$

790.125

CAPITALIZED INTEREST: . . . . . .

GROSS OPERATIHG REVENUES ..........

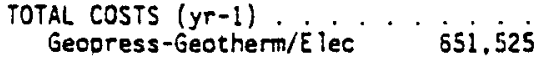

$\$ 3.502,789$

Methane Gas

Bulk Water/Salt

108,806

324,975

Bott led Water

Rose/Greenhouse

Fish/Aquaculture

246,750

Cont ingencies

Geopress-Geotherm/E lec ' ' $\dot{9} 2 \dot{5}, \dot{b} 7 \dot{6}$

Methane Gas

8ulk Vater/Salt

571.196

Bott led Vater

Rose/Greenhouse

1.626 .003

1.844 .176

Fisn/Aquaculture

4.968 .051

$\$ 8.867 .466$

$2,199,750$

$5,701,500$

$.465,262$

FIHAKCIAL/TAX/ECONOMIC INPUTS :

Oiscount Rate (IRR)

Debt Ratio

Interest Rate

Debt Life

Depreciation Life

Royalty ( $X$ of revenue)

Taxes :

Federal Tax

State Tax

Severance Tax

Ad Va lorem Tax

Inflation Rate

Cost Escalation :

Deve lopment and Capital Cost

Op/Post-Op Costs Expenses

$15.0 \%$

$11.0 x$

3 yrs

$15.0 \times$

$38.0 x$

$2.0 \%$

$5.0 \%$

$7.2 \%$

$5.0 \%$

$0.0 \%$

$0.0 \%$

Revenue Escalation

Electricity

Bulk \& Bottled Water/Salts

Methane Gas

Fish/Aquacuiture

Roses/Greenhouse

$0.0 \%$

$1.0 \%$

$0.0 \%$

$0.0 \%$

GEOPRESSURED-GEOTHERMAL (brine) WELL CHARACTERIST

Well Life

8rine Temp Surface

Barrels per Day

Gas Concentration / Barrel

Gas Quality

Botton Hole Pressure

Flowing Welthead Pressure
10 yrs
300 F

20.000 BPO

$80 \mathrm{scf} / \mathrm{B}$

$90 \%$

15.000 psi

2,000 psi

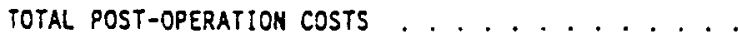

$\$ 301.346$

SALVAGE (at end of projec: life) ......... 
AHALYSIS OF VELL: Large Volume, Moderate Temp, Geopressured-Geothemal Well

MOOEL ANALYSIS: No Electricity/Methane/Salts/Bulk Vater Products

RESULTS :
10-YR NPV
$\$ 546.633$
Discounted Payback
8.2 years

BASE YEAR and CONTRACT OOLLARS :

1991

FINANCIAL SUMMARY:

$\begin{array}{lr}\text { TOTAL PRE-OPERATION/DEVELOPMENT/CAP ITAL COS C } \\ \text { Borrowed } & 1,709.400 \\ \text { Owners Equity } & 3,251.325 \\ \text { Capitalized Interest } & 94.017\end{array}$

COPTITATI2Ed Interest

TOTAL PRE-OPERATION/DEVELOPKENT/CAPITAL COSTS ... \$5,054,742

TOTAL OEVELOPMENT COST $2,199^{\circ}, 750^{\circ}$

Geopress-Geothermal Ve $^{\circ} i^{\circ} 2.199^{\circ}, j 50^{\circ}$

Pipeline Right-of-Way 0

TOTAL CAPITAL BUILDING/EQUIPMENT COST

$\begin{array}{ll}\text { Geotherm \& Elec Eq } & 199,500 \\ \text { Gas Separator \& Trans } & 120,750\end{array}$

Gas Separator $\$$ Trans $\quad 1,509,750$

Bulk Hater/Salt
Bott led Water

Rose/Greenhouse

Fish/Aquaculture

Work ing Funds

$2,310,000$

$\$ 5,054,742$

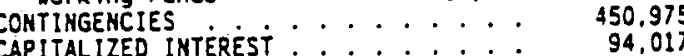

$, 509,750$

2.310 .000

GROSS OPERATING REVENUES ........... \$1.672.425

TOTAL COSTS (yr-1)
Geopress-Geotherm/E iec
Heó. 450

Methane Gas 108.806

Bulk Vater/Salt $\quad 324,975$

Bottled Water

Rose/Greenhouse

Fish/Aquaculture

Contingencies 80.023

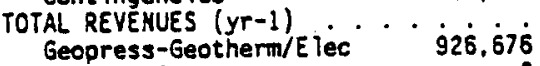

Methane Gas

Bulk Vater/Salt

Bott led Water

Rose/Greenhouse

F ish/Aquaculture

$1,626,003$

$2,552,679$
FINANCIAL/TAX/ECONOMIC IMPUTS :
Ot SCOUnt Rate (IRR)

Debt Ratio

Interest Rate

Debt Life

Depreciation Life

Royalty ( $x$ of revenue)

Taxes :

Federal Tax

State Tax

Severance Tax

id Valorem Tax

Inflation Rate

Cost Escalation :

Deve looment and Capital Cost $0.0 \%$

Op/Post-0o Costs \& Expenses, $0.0 \%$

Revenue Escalation :

Electricity

Bulk \& Bott led Water/Salts. $0.5 \%$

Methane Gas

Fish/Aquaculture

Roses/Greenhouse

$1.0 \%$

$0.0 \%$

$0.0 \%$

GEOPRESSURED-GEOTHERMAL (brinE) WELL CHARACTERISI

Well Life

Brine Temp Surface

Barrels per Day

Gas Concentration / garre

Gas Quality

Bottom Hole Pressure

F lowing Wellihead Pressure

10 yrs

20,000 BPO

$80 \mathrm{scf} / \mathrm{s}$

$90 \%$

$15,000 \mathrm{psi}$

2,000 psi

TOTAL POST-OPERATION COSTS ........... . \$301,346

salyage (at end of project life) ........ so 
AMALYSIS OF WELL: Large Volune, Moderate Temp. Geopressured-Geothermal We 11 MOOEL NAME: G610-A2

HOOEL ANALYSIS: No Electricity/Hethane/Agri \& Aquaulture Products

RESULTS :
10-YR NPV
$(\$ 18,902)$
Discounted Payback
0.0 years

BASE YEAR and CONTRACT DOLLARS :

1991

FIMANCIAL SUMMARY:

TOTAL PRE-OPERATION/OEVELOPMENT/CAPITAL COSTS ....\$4.523.558

Sorrowed $\quad 1.501 .500$

Owners Equity 2.939 .475

Capitalized Interest $\quad 82.583$

INVESTHENTS/EXPENSES/REVENUES :

TOTAL PRE-OPERATION/DEVELOPMENT/CAPITAL COSTS ... \$4,523,558 TOTAL OEVELOPMENT COST Geopress-Geotherna i ve it $i, i 99^{\circ}, 750^{\circ}$ Piceline Right-of-Way

TOTAL CAPITAL BUILOING/EQUIPMENT COST. Geotherm \& Elec Eq 199,500 Gas Separator \& Trans $\quad 120.750$ Bulk Water/Sa it Bottled Water Rose/Greenhouse $\quad 887.250$ Fish/Aquaculture $\quad 210,000$ Working Funds $\quad \$ 20.000$

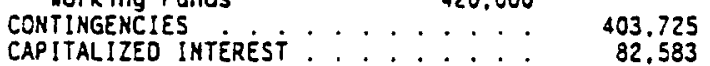

GROSS OPERATING REVENUES . . . . . . . . . . $\$ 1,293,900$

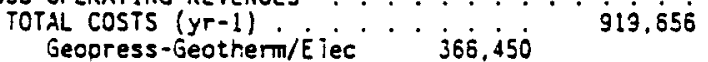
Methane Gas $\quad 108,806$ Bulx Vater/Sa it Bottled Water Rose/Greenhouse

42.000

Cont ingencies $\quad 79.787$

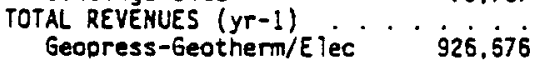
Hethane Gas

Bu ik Vater/Sa It

Bott led Water

Rose/Greenhouse

Fish/Aquaculture

$1,226.400$

60.480

2.213 .556

$1.837,500$
FINANCIAL/TAX/ECONCMIC IMPUTS :

Discount Rate (IRR)

Debt Ratio

interest Rate

Debt Life

Deprectation Life

Roya lty ( $x$ of revenue)

Taxes :

Federal Tax

State Tax

Severance Tax

Ad Valorem Tax

inflation Rate

Cost Escalation :

Develooment and Capital Cost Op/Post-Op Costs \& Expenses Op/Post-Op Costs

Electricity

Bulk \& Bottled Water/Salts

Methane Gas

Fish/Aquaculture

Roses/Greenhouse

$15.0 \%$

$40.0 \times$

$11.0 \%$

3 yrs

$15.0 \%$

$38.0 \times$

$2.0 \%$

$5.0 \%$

$7.2 \%$

$5.0 \%$

$0.0 \%$

$0.0 \%$

$0.0 \%$

0.5

$1.0 \%$

$0.0 \%$

GEOPRESSURED-GEOTHERMAL (brine) WELL CHARACTERIST Yell Life

Brine Temp Surface

Barrels per Day

Gas Concentration / garrel

Gas Quality

Botton Hole Pressure

Flowing Wellhead Pressure
10 yrs

$20.000 \mathrm{BPD}$

$80 \mathrm{scf} / 8$

$90 \%$

15.000 psi

2.000 psi

TOTAL POST-OPERATION COSTS

$\$ 301.345$

SALVAGE (at end of project life) 
AMALYSIS OF WELL: Large Volume. Moderate Temp, Geopressured-Geothermal Well MOOEL NAME: GGIO-A2

$08: 44: 33$ dy : time

MODEL AMALYSIS: Electricity $\$ 50.060 /$ Methane/Agri Aquaulture Products

RESULTS
10-YR NPV
$(\$ 1,511,389)$
Discounted Fayback
0.0 years

BASE YEAR and CONTRACT COLLARS :

1991

FINANCIAL SUMMARY:

TOTAL PRE-OPERATION/OEVELOPMENT/CAPITAL COSTS . . . \$7,628,036 Borrowed

Giners Equity

Capitalized Interest.

\section{$2,716,560$}

149,411

INVESTMENTS/EXPENSES/REVENUES :

TOTAL PRE-OPERATION/OEVELOPHENT/CAPITAL COSTS

TOTAL OEVELOPMENT COST $\cdot{ }^{\prime} \cdot \dot{i} \cdot \dot{ } \dot{ }^{\prime}$ Geopress-Geothermal Well $2.199,750$ Pipeline Right-of-Way 0

TOTAL CAPITAL 8UILDING/EQUIPHENT COST Geotherm \& Elec Eq 2.961 .000 $\begin{array}{lr}\text { Gas Separator } 3 \text { Trans } & 120.750 \\ \text { Bulk Water/Salt } & 0\end{array}$ Bottled Water

Rose/Greenhouse $\quad 887.250$

Fisin/Aquacuiture $\quad 210.000$ Working Funds $\quad 420.000$

CONTINGENCIES ........... . . . . . . 679.875

CAPITALIZED INTEREST ......... 149,411

GROSS OPERATING REVENUES . . . . . . . . . . . $\$$. \$1,551.513

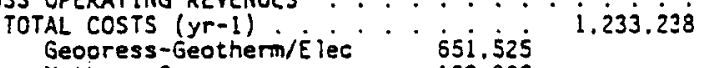

Methane Gas 108.805

Bulk Vater/Salt

Bott led Water

Rose/Greenhouse

108.294

TOTAL REVENUES $(y r-1)$. . . $92 \dot{6}, \dot{6} 7 \dot{6}$

Bulk Water/Salt

Bottled Water

Rose/Greenhouse

$F$ ish/Aquaculture

$1,226,400$

60,480

$2,784,751$
FINANCIAL/TAX/ECONOMIC IMPUTS

Oiscount Rate (IRR)

Debt Ratio

Interest Rate

Debt Life

Depreciation Life

Royalty ( $X$ of revenue)

Taxes :

Federa T Tax

State Tax

Severance Tax

Ad. Va iorem Tax

Inflation Rate

Cost Escalation:

Development and Capita l Cost

Op/Post-0p Costs \& Expenses $\quad 0.0 \%$

Revenue Escalation:

Electricity

Bulk \& Bot: led Water/Saits $\quad 0.5 \%$

Methane Gas

Fish/Aquaculture

$1.0 \%$

Roses/Greenhouse

$0.0 \%$

GEOPRESSURED-GEOTHERMAL (brine) WELL CHARACTERIS: Well Life

Brine Temp a Surface

Barrels per Day

10 yrs

Gas Concentration / Barrel

Gas Quality

Bottom Hole Pressure

000 8P0

Flowing Vellhead Pressure

$\$ 301,346$

so

SALVAGE (at end of project life) ......... 
ANALYSIS OF VELL: Large Volume. Moderate Temp, Geopressured-Geothermal Well MODEL MAME: GGIO-A2

HODEL ANALYSIS: Electricitya\$0.025/Methane/Agri \& Aquaulture Products

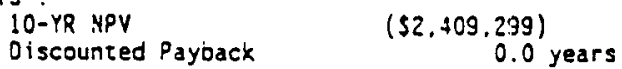

BASE YEAR and CONTRACT DOLLARS :

1991

FIMANCIAL SUMMARY:

TOTAL PRE-OPERATION/DEVELOPMEMT/CAPITAL COSTS *.\$7.628.036

Borrowed $2,716,560$

Owners Equity $\quad 4,762.065$

Capitalized Interest $\quad 149,411$

INVESTMENTS/EXPENSES/REVEMUES :

TOTAL PRE-OPERATIOH/OEVELOPMENT/CAPITAL COSTS TOTAL OEVELOPMEMT COST

Geopress-Geotherma i bei i 2 . ig9.j50 Pipel ine $R$ ight-of-Yay
TOL CAPITAL BUILOING/EOUIPMEYYT COST.

2. 199.750

$\$ 7,628,036$ Geotherm \& Elec Eq 2.961 .000 Gas Separator \& Trans 120,750 Bulk Yater/Salt

4.599 .000 Bott led Hater Rose/Greenhouse $\quad 887.250$ Fish/Aquaculture $\quad 210.000$ Working Funds $\quad 420.000$

CONTINGEHCIES . . . . . . . . . 679.875

CAPITALIZED INTEREST . . . . . . 149.411

GROSS OPERATING REVENUES .........

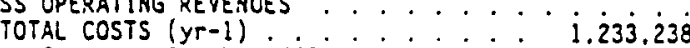
Geopress-Geotherm/E lec ' $\quad 65 i, 525$ Methane Gas 108.806

Bulk Water/Salt

Bottled

Rose/Greenhous

Fish/Aquaculture

42.000

Cont ingencies $\quad 108.294$

TOTAL REVENUES $(y r-1)$. * · $\dot{9} \dot{6} \dot{6} \dot{5} \dot{6}$

Methane Gas 237.998

Bulk Yater/5alt

Bottled Water

Rose/Greenhouse

$\$ 1.218 .316$

$F$ ish/Aquacu iture

1.226 .400

50,480

$2,451,554$

$\$ 301,346$

SALVAGE (at end of project life) .........

FINANCIAL/TAX/ECONOMIC INPUTS

Discount Rate (IRR)

Debt Rat io

Interest Rate

Debt Life

Depreciation Life

Royalty ( $X$ of revenue)

Taxes

Federal Tax

State Tax

Severance Tax

Ad Va lorem $T a x$

Inflation Rate

Cost Escalation:

Development and Capital Cost op/Post-op Costs \& Expenses Reyenue Escalation:

Electricity

Bulk \& Bottled Yater/Salts

Methane Gas

Fish/Aquaculture

$15.0 \%$

$40.0 \%$

$11.0 \%$

3 yrs

$15.0 \%$

$38.0 \%$

$2.0 \%$

$5.0 \%$

$7.2 \%$

$0.0 \%$

$0.0 \%$

$0.0 \times$

$0.5 x$

$1.0 \times$

$0.0 \%$

Roses/Greenhouse

$0.0 \%$

GEOPRESSUREO-GEOTHERMAL (brine) WELL CHARACTERIST Yyell Life

Orine Temp Surface

10 yrs

Barrels per Day

Gas Concentration / Barrel

Gas Quality

Botton Hole Pressure

$20.000 \mathrm{BPO}$

$80 \mathrm{scf} / 8$

$90 \mathrm{x}$

Flowing Wel lhead Pressure

15.000 ps

2.000 psi 


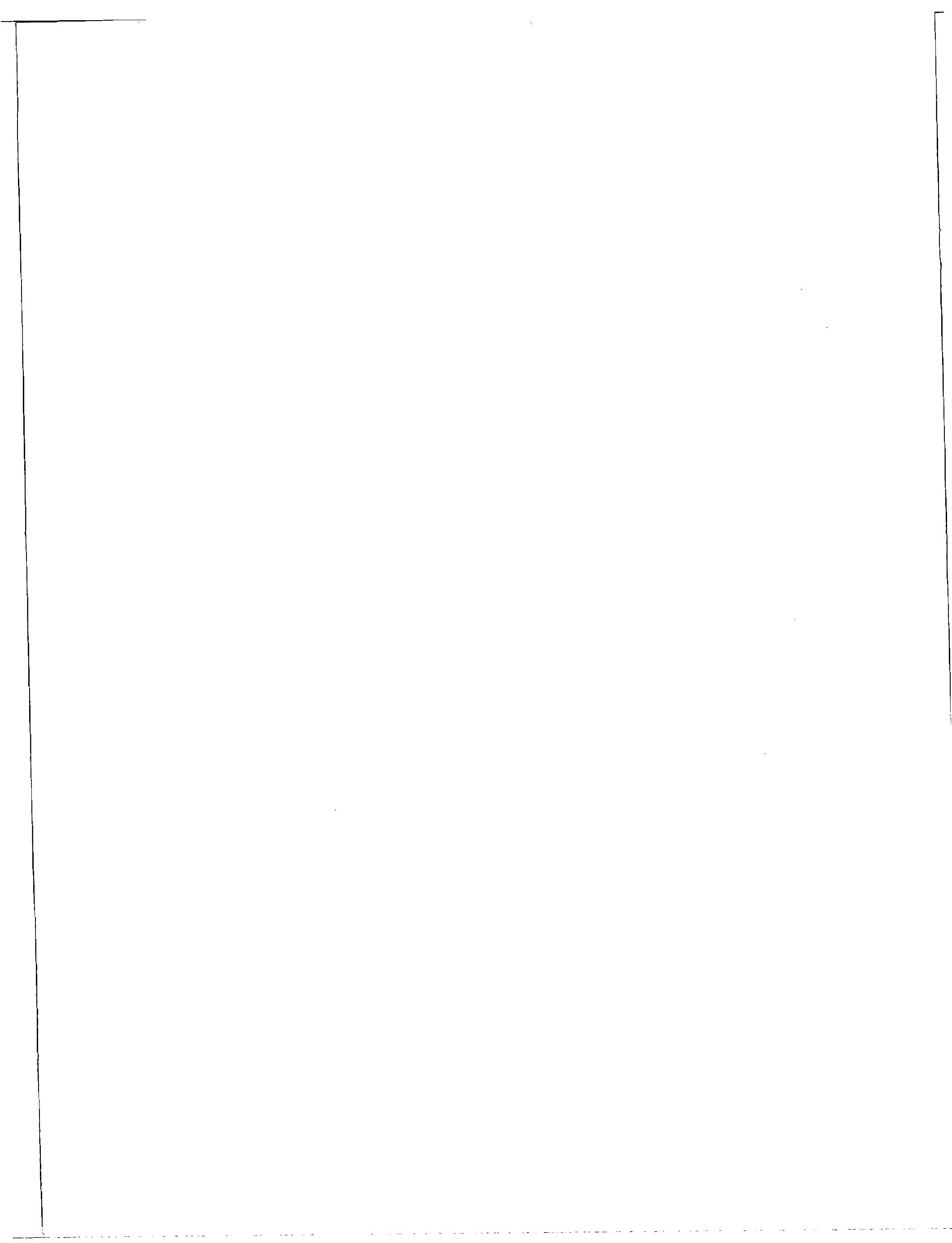




\section{APPENDIX D}

PRELIMINARY FEASIBILITY FOR GREENHOUSE/AQUACULTURE FACILITY AT PLEASANT BAYOU, TEXAS.

(P. J. LIENAU, OREGON INSTITUTE OF TECHNOLOGY GEO-HEAT CENTER)

D-1 



\section{FAX TRANSMITTAL}

DATE: 20 JU1V 1990

TIME: 6:00 am

FAX NUMBER: $503-885-1115$

TO: QRESON TUSTITHIE OE TECHMOTOCY GEO-YEAT CENTER

\section{ATTN: PAUL IIENAYU}

REFERENCE: QUOTATION REQUEST

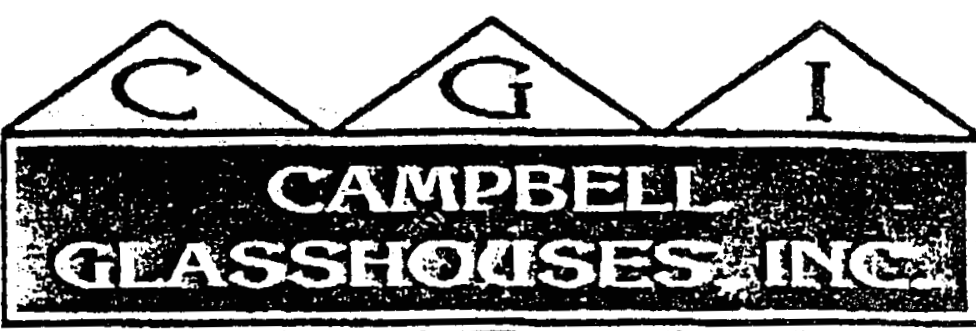

i fagricator o instablation

DEsien - CONSULTIMO - FABRICATION - INSTALLATION COMPLETE GREEMHOUSE SYSTEMS

\section{P. O. Box 678}

LINCOLNSHIRE, ILLINOIS 60069
REMARKS: Three Proposals are artached as requested.

Please let me know how I can be of further assistance

at this time.
24-HOUR FAX

708-541-0217
TELEPHONE

$708-541-7272$

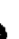

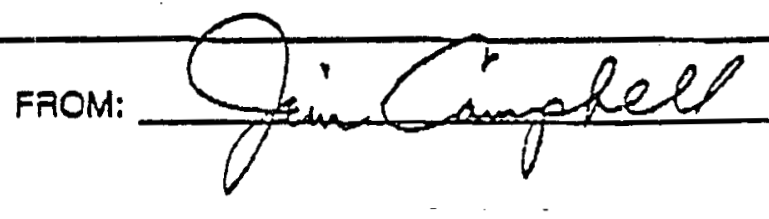

D-3 


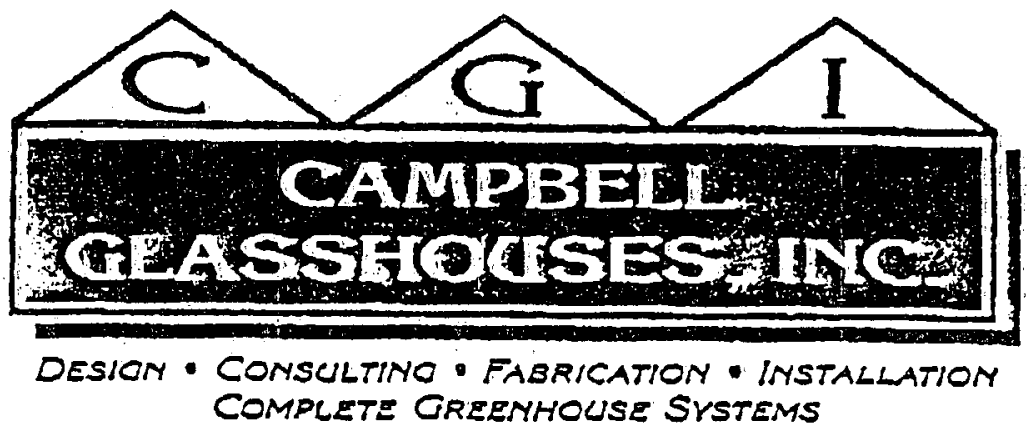

19 July 1990

Paul Iienau

Geo-ireat Center

OREGON INSTITUTE OF TECHNOLOGY

3201 Campus Drive

Klamati Falls, Oregon 97601

Dear Mr. Lienau:

Thank you for your recent inquiry regarding proposal quotations for your proposed facility in Texas. Fer your request I've attached three separate proposals for the different phases of the project which you described.

Please understand that these are budget prices which will be confirmed when the final details and building schedule are determined.

I'll be sending you a packet of descriptive and technical licerature for your files. Also I did not frclude a computer system quotation at this time, but I will be happy to have an exact specified quotation prepared if that will be of help to you now.

Please FAX today any response or further requests for assistance. I will be pleased to work with you in bringing this project to a positive reality.

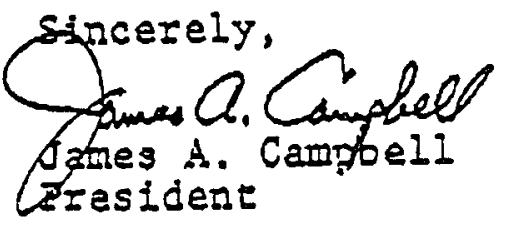

Encl. D-4

P. O. BOX 678, LINCOLNSHIRE, ILUMOLS 60069 - TERPHONE: 708-541.7272 • FAX: 708-541.0217 


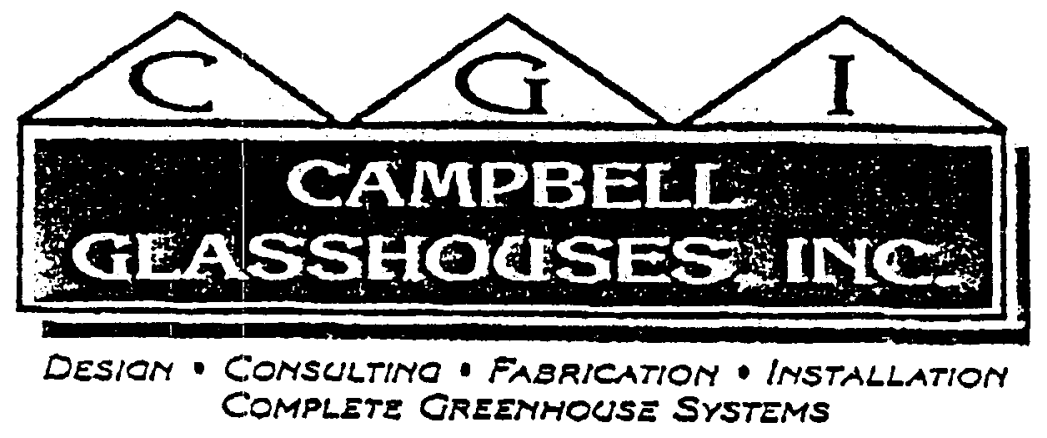

PROPOSALI

PAUL IIENAU

Geo-heat Center

Oregon Institute of Technology

3201 Campus Drive

Kiamati Falls, Oregon 97601

CAIPBELI GLASSHOUSES proposes to provide materials and 1nstallation labor for the following facility planned to be built in Texas:

STRUCTURES: Three (3) Greeniouses, each 42' $x$. $348^{\text {m }}$

One (1) Greenhouse, $2 I^{\prime} \times 348^{\prime}$

Total square footage $=51,156$

Houses to be gutter-connected together. Gutters to be set $10^{\prime}$ above grade. Trusses to be set 12 ' on centers. The large houses to each have nine ( 9 ) rung of roof purlins and the small house to have five (5) zuns.

GIIIING :

OPTION 1 - 5 oz. Fiberglass Panels

All surfaces to be glazed with 5 oz. clear corrugated Fiberglass panels.

OPTION 2 - 8 Polycarbonate Panels

All surfaces to be glazed with 8 m clear polycarbonate structured panels with an aluminum glazing bar system.

VENTILATION: Each house to have two (2) continuous runs of ridge verts, 56 " wide, to be operated automatically and independently.

SCREENS :

Each vent opening to be provided with an insect screen in an aluminum frame.

SEATING:

A total of twenty-eight (28) hot water lnit heaters with fourteen (14) Fact tan systems complete with poly distribution tubing to be installed. 


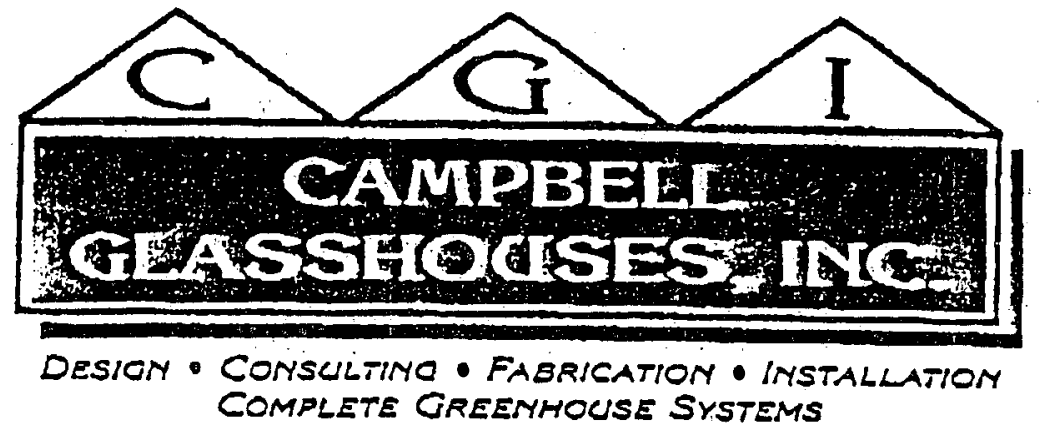

PAUL LIENAY page 2

COOLING:

An evaporative pad cooling system, $6^{\prime \prime} \times 4^{\prime} \not 348^{\prime}$, to be installed. The opposite sidewall to contatn twenty-two (22) exhaust Eans, 48", I H.P., conplete with slant wall box, blade guard, and automatic shutter.

EREIGTT:

F.0.3. jobsite prepaid.

TOTAI PRICE: OPTION 1 GLAZING: $\$ 345,950$

OPTION 2 GLAZING: $\$ 456,000$

TERMS :

intualiy acceptable terns to be arranged.

ACCERTANCE: OPTION 1:

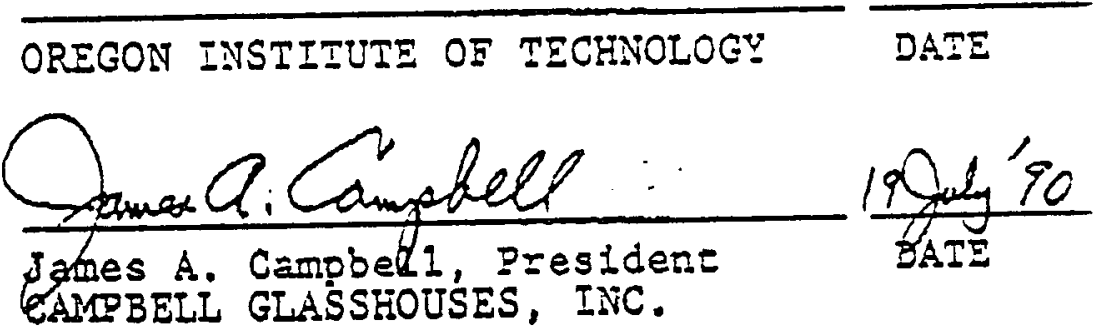

OPTION 2:

OREGON INSTITUTE OF TECHNOLOGY DATE

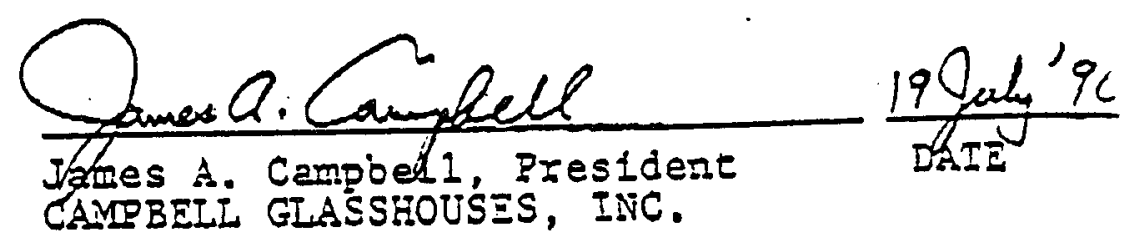




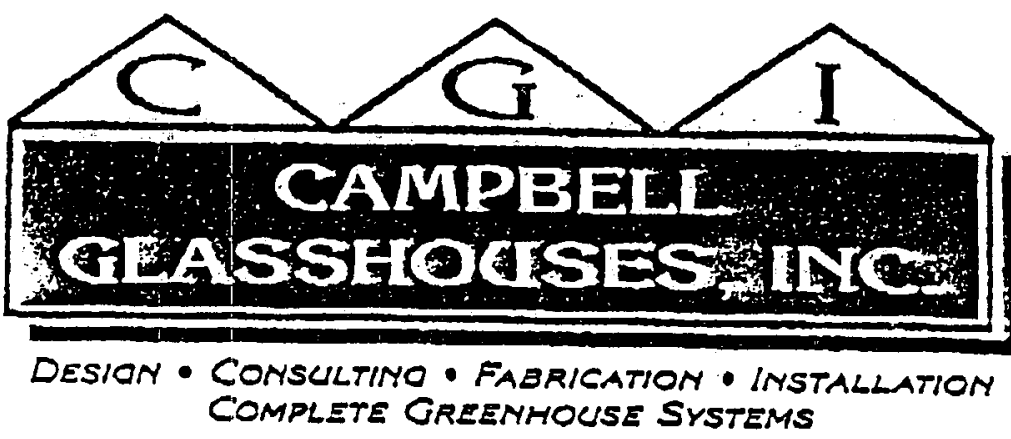

PROPOSAL II

EALT LIENAU

Geo- Heat Center

Oregon Institute of Technology

3201 Campus Drive

Klamati Ealis, Oregon 97601

CAIPBII GLASSHOUSES proposes to provide material and installation labor for the following facility to be built in Texas:

SIRUCTURES ;

One (1) Greenhouse, 36'x 1921 $72^{\circ}$

Total square footage $=6,912$

Gutters to be set $10^{\prime}$ above grade. Trusses to be set on $12^{\prime}$ centers. Nine (9) runs of roof purlins.

GLAZING:

All surfaces to be glazed with 5 oz, clear corrugated Fiberglass parels.

COOLINE :

One sidewall to contain ten (10) exhaust fans, $42 "$, 1/2 H.P., complete with slant wall box, blade guard, and automatic shuter. The other sidewall to a continuous tur of vent, $48^{\prime \prime}$ wide, to be operated automatically.

VEAIING:

Four (4) hot water unit haeters with two (2) Fact fan systems to be installed complete with poly distribution tubing.

FREIGHT: $\quad$ F.O.B. jobsite prepaid.

TOTAI PRICE: $\quad \$ 50,500$

TERMS: Mutually acceptable terms to be arranged.

ACCEPTANCE:

OREGON INSTIIUTE OF TECHNOLOGY

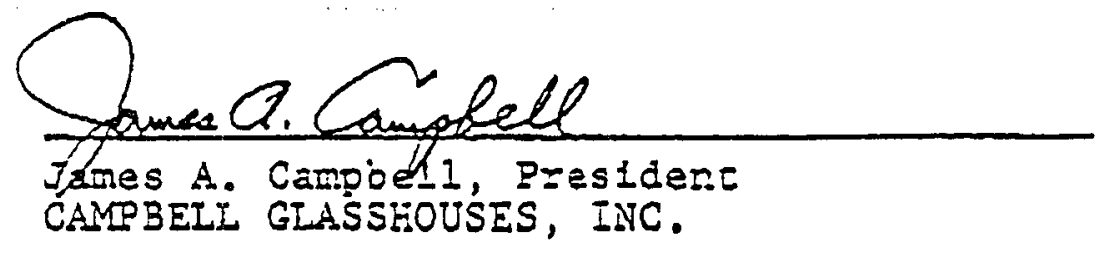

DATE

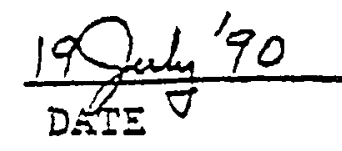




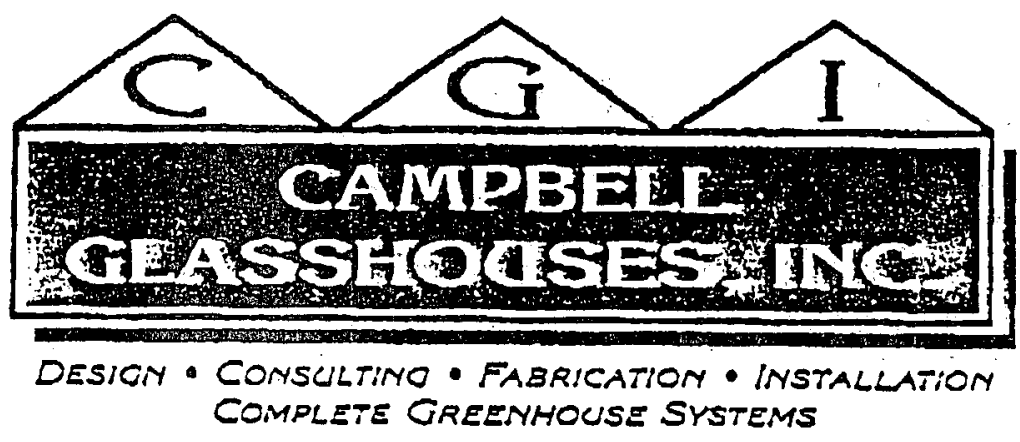

PROPOSAI III

PAUL LIENAU

Geo-Heat Center

19 JuIy 1990

Oregon Institute of Technology

3201 Campus Drive

Klamath Falls, Oreson 97601

CAMPBEL GLASSHOUSES, proposes to provide materials and installation labor for the following facility to be built in Texas:

STRUCTURES: One (1) Service Building, 50'x $84^{\prime}$

Total square footage $=4,200$

Gutters to be set $14^{\prime}$ above grade. Irusses to be set on $12^{\prime}$ centers. Eleven (I1) runs of roof purlins.

GLAZING :

All surfaces to be glazed with $26 \mathrm{ga}$. cozzugated steel panels.

COOLING: Not incluced in quotation.

FEATING: Not included in guotation.

DOOR:

One 10'X I2' overhead door to be provided.

FREIGAT: $\quad F .0 . B$. prepaic to joisite.

IOTAL PRICE: $\quad \$ 42,000$

TERYS :

Mutually acceptable terms to be arranged.

ACCEPTANCE:

OREGON INSTITUTE OF TECHNOLOGY

DATE

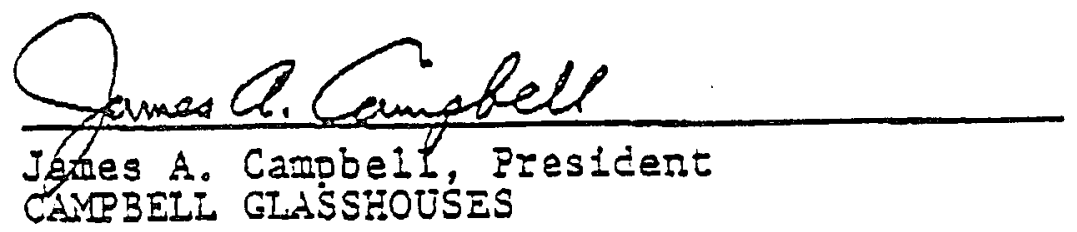

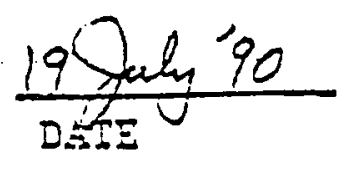




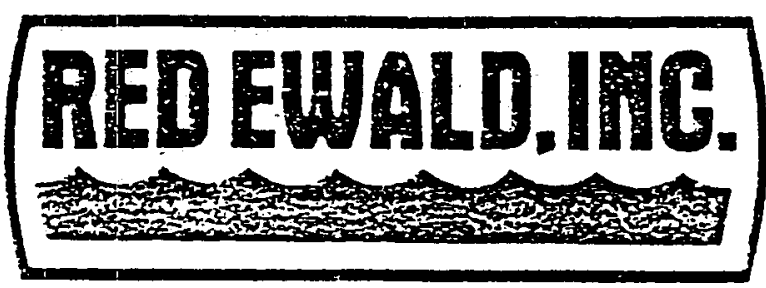

\section{SCHEMATIC DRAWING OF HIGH DENSITY RECIRCULATING GROWOUT SYSTEM}
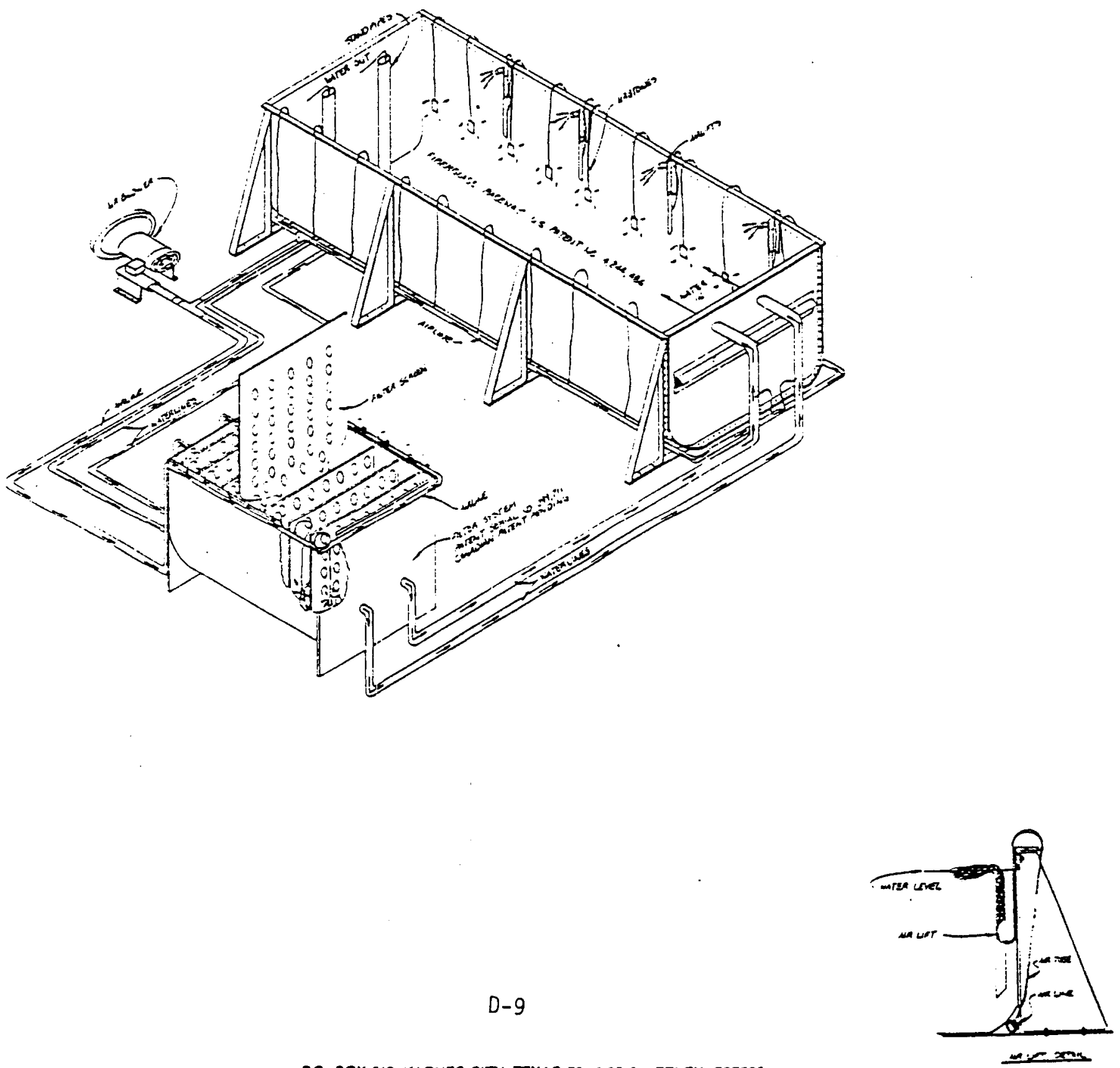


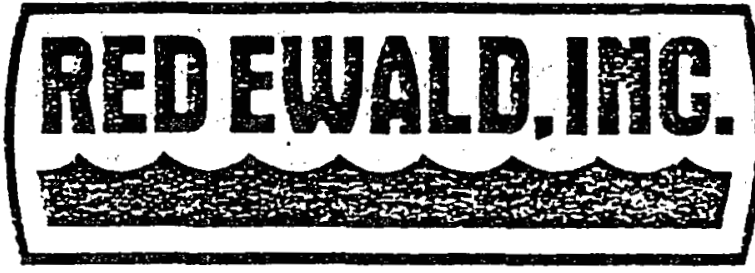

10,000 GALLON RACEWAY CULTURE SYSTEM

Quantity

1

1

1
Description

RW-7 8' $\times$ 4' $\times$ 45', Fiberglass Raceway Tank with four 4" PVC fittings

VRSF-16 4' 4 $^{\prime} \times 16^{\prime}$, Vertical Screen Filter Tank with 14 screens and with four 4" PVC fittings

Aeration-Plumbing Package, includes a $2 \mathrm{Hp}, 1$ phase regenerative air blower, airstones, PVC pipe, PVC fittings, tubing, and miscellaneous hardware needed for system set up.

Price for one (1) 10,000 gallon Raceway System..................\$15,280.00

PVC parts may, in some locations, be purchased for less money than through Red Ewald, inc. (Approximate savings $\$ 100$ to $\$ 500$ ).

Note: Price does not include any shipping or crating charges.

This Price List effective March 10,1986. Prices, materials, and/or specifications subject to change with or without notice. Warranty on tanks limited to repair or replacement of tanks only. 


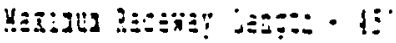

\begin{tabular}{|c|c|c|c|c|c|c|}
\hline Yode: & ris: & 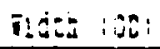 & IE: & 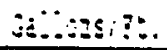 & 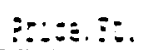 & :Z::: \\
\hline$\overline{a ̈ a-!}$ & $i^{\prime}$ & 81 & $\because$ & $i j$ & 859.29 & $\operatorname{sis} \theta \operatorname{sen}$ \\
\hline $37-:$ & 8: & $!$ & $: "$ & 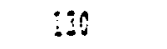 & $9 . .80$ & 536.26 \\
\hline $37-:$ & $\mathfrak{g}^{\prime}$ & $\because{ }^{\prime}$ & $\because$ & $: \vdots \vdots$ & 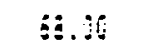 & 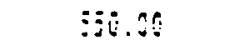 \\
\hline $3 x-1$ & 81 & $11^{\prime}$ & $\vdots$ & $11 ;$ & $i\lfloor. \dot{v}:$ & Q́śi. \\
\hline $3 x-j$ & $10^{\circ}$ & :?' & $!^{\prime}$ & $1 ! 5$ & $i \pm .00$ & 650.30 \\
\hline$\hat{i} \mathbf{i}-\dot{z}$ & $10^{\prime}$ & $1]^{\prime}$ & $!^{\prime}$ & $\because: ?$ & 35.96 & $5: 5.00$ \\
\hline $3 i-\vdots$ & $8:$ & $! !^{\prime}$ & $!$ & $\therefore 9$ & : & : \\
\hline$\dddot{a} i-\dot{3}$ & $!$ & $\because:$ & $\vdots:$ & 85 & 53.90 & 40.18 \\
\hline 35 & $!$ & $i^{\prime}$ & $!$ & $\vdots ! \vdots$ & $\vdots .00$ & 930.88 \\
\hline
\end{tabular}

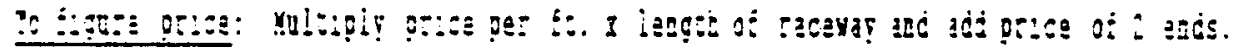

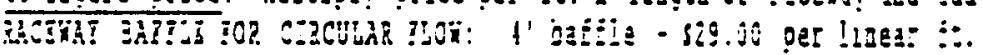

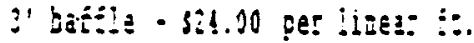

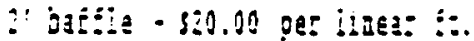

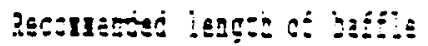

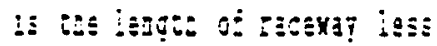 its vijt:.

\section{RECTANGULAR FISH REARING TROUGHS}

\begin{tabular}{|c|c|c|c|c|c|c|}
\hline Yosंe? & Galloss & Es!ọt: & iije: & 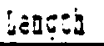 & ie: & $5: 26 \mathrm{~s}$ \\
\hline$? n+3 !$ & 30 & $12^{2}$ & $20^{\prime}$ & $2 ! !$ & 18 ijs. & $8 \quad 22.00$ \\
\hline$? \geq ? \cdot !$ & $\because:$ & $\xi$ & $12^{\prime}$ & 1081 & 30 ios. & 110.10 \\
\hline$[1 ?-i !$ & 32 & 97 & $: 1$ & 192 & 18 liss. & $: 76.00$ \\
\hline !2?-9 & 40 & $g^{\prime}$ & $24^{\prime}$ & $12^{\prime}$ & 25 lbs. & 122.00 \\
\hline ! : & 50 & $!: !$ & $\because{ }^{\prime}$ & $!:{ }^{2}$ & If & ¿22.00 \\
\hline ?2!--29 & $\$ 1$ & 8 & $? 9^{1}$ & $9 \ell^{\prime}$ & 15 las. & 170.80 \\
\hline$? \mathrm{m?-!?}$ & 18 & 181 & $26^{2}$ & $\vdots 9$ & 38 lbs. & 149.00 \\
\hline$? 3:-35$ & 30 & $!: !$ & $\because ?$ & $34^{2}$ & !2 13s. & 160.00 \\
\hline !9?-? & 100 & $\because \because$ & ??' & 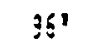 & 15 MS. & 070.90 \\
\hline$? ?: ! 9$ & 100 & $2 !$ & $23^{t}$ & 251 & 12 los. & 570.00 \\
\hline [1:-2! & 110 & $10^{\prime}$ & $: 51$ & $\because: !$ & 50 ibs. & $1: 3.00$ \\
\hline ?3?+3! + & $1: 0$ & $: !^{\prime}$ & $\because 1$ & $3 \varepsilon^{3}$ & so los. & $: 93.00$ \\
\hline [??-?] & 120 & i!' & ¿!' & 48 & $\$ 3$ ibs. & 205.00 \\
\hline$? 3:-3 !$ & 150 & 21 & $\therefore 1$ & $! ! ! !$ & 39 ibs. & 257.10 \\
\hline $79:-45$ & 195 & $! \xi !$ & $2 n^{2}$ & $: 4 !^{\prime}$ & 125 ihs. & 383.00 \\
\hline $73:-? !$ & $\$ 80$ & $222^{\prime}$ & $! 4^{\prime}$ & $4 !$ & 110 lis. & $\$ 75.20$ \\
\hline $131-3$ & 240 & !?' & 151 & 928 & 120 Ibs. & 397.00 \\
\hline $13 !-96=$ & $: 10$ & $30^{2}$ & !"' & 181 & \$50 las. & 506.90 \\
\hline ?3:-92 & $2 ! 5$ & 181 & 93 & 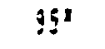 & 120 ibs. & 194.06 \\
\hline$? 3: ?-! 9$ & 280 & 301 & $30^{\circ}$ & $16^{\prime}$ & 150 ids. & 198.00 \\
\hline ?!"-? & 300 & $2 !^{8}$ & $: 5 !$ & $120^{\prime}$ & iso libs. & $\$ 19.00$ \\
\hline $13:-30$ & 900 & 28 & $20^{\circ}$ & $! 301$ & 195 ibs. & 550.00 \\
\hline$m ?-? !$ & 345 & 2!" & 281 & $129^{\prime}$ & :10 !hs. & $\$ \$ 0.20$ \\
\hline$? 37-? 3$ & 670 & 961 & 371 & $84^{\prime}$ & 250 libs. & $\$ 15.00$ \\
\hline$? 8:-9.82$ & $\$ 00$ & $2 ! !$ & $24^{\prime}$ & $2 ! 6^{3}$ & 390 Ibs. & 1.255 .00 \\
\hline$? 19-13$ & 800 & 201 & 48 & $14^{*}$ & :50 las. & 882.90 \\
\hline$? 9 ?-14$ & 750 & $20^{\circ}$ & $60^{3}$ & $144^{\prime \prime}$ & 300155. & 1.045 .00 \\
\hline $731-19=2$ & 1000 & 364 & 39 & $180^{\prime}$ & soo bos. & ...995.00. \\
\hline
\end{tabular}

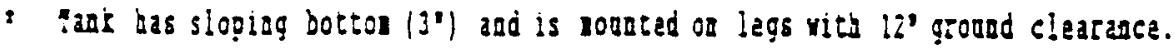

37 Tant bas beaciog tib to preveat boviag in sidevalls.

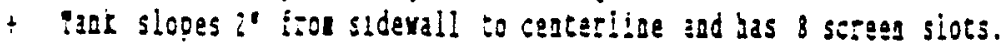

VOTE: Dimensions are based on 1.0. measurement at the top. Check with factory if 0.0. is critical. 


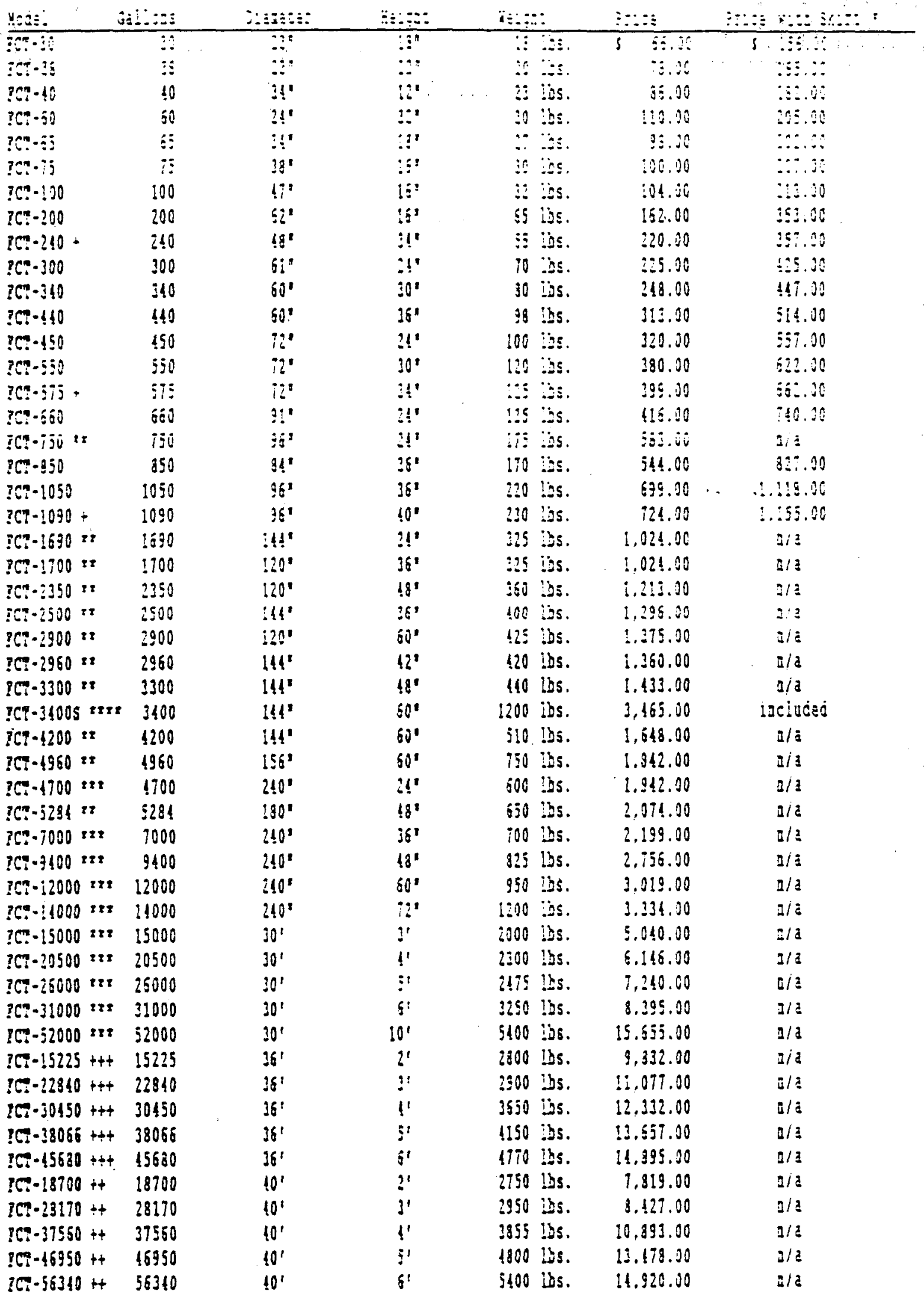

NOTB: FOR ADDITIONAL INFORMATION ON ROUND FISH CULTURB TANRS, SEB TOP OF PAGE THRRB. 
NOTES CONTINUED EROM PAGE TWO.

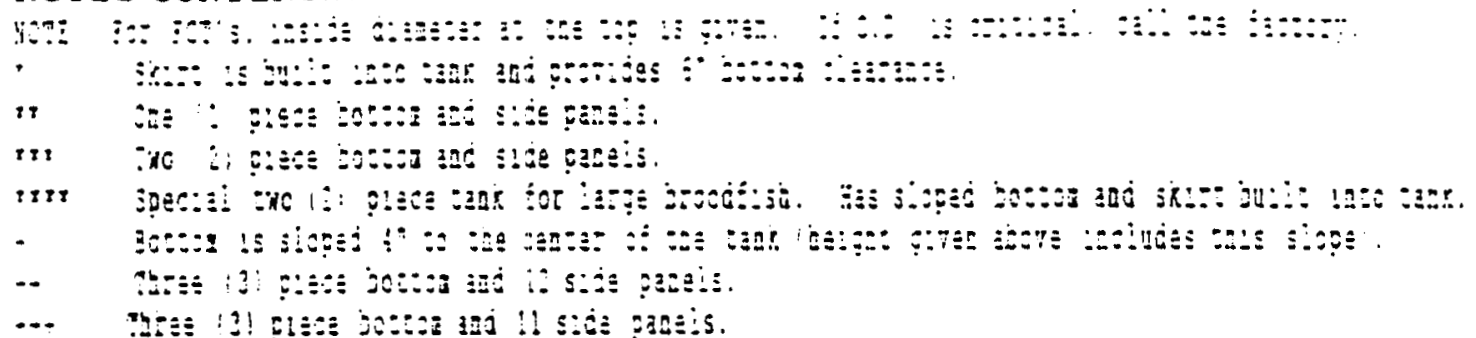

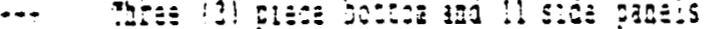

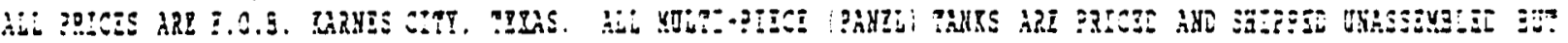

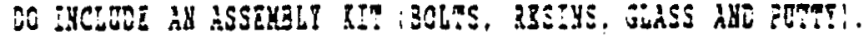

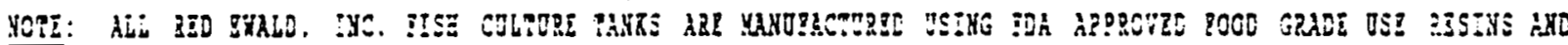
GJLCJA?S.

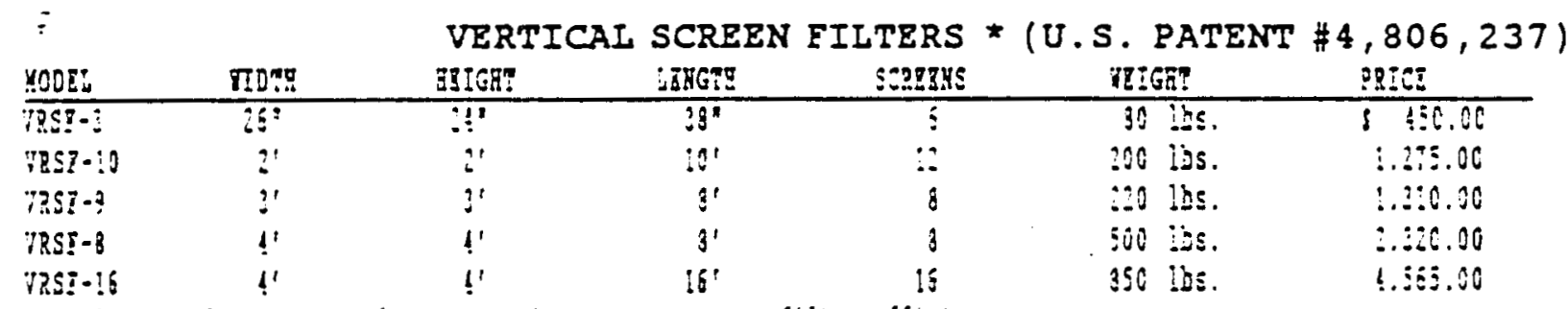

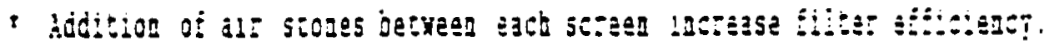

\section{CONB BOTTOM REARING TANKS}

\begin{tabular}{|c|c|c|c|c|c|c|c|c|}
\hline yoog: & dilons & CONY IYGH & 0.1. & Deg?g & $n$ & 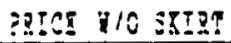 & 29008 V/ST:3? & \$m. \\
\hline $63 ? \cdot 1$ & 120 & so jeç. & $30^{\circ}$ & 301 & 70 ias. & 8226.10 & 3930.98 & $59^{\prime \prime}$ \\
\hline $537-?$ & 40 & 45 jeq. & !! & ift & $20: 55$. & 131.30 & 205.00 & $48^{\circ}$ \\
\hline $63 T \cdot \hat{j}$ & 130 & !j deọ. & $26^{2}$ & !? & jo libs. & $20 \div .00$ & 378.00 & $50^{2}$ \\
\hline CB? -1 & 500 & 45 deg̣. & 181 & $300^{\prime}-(-2)$ & 150 ibs. & 577.00 & 866.00 & 38 ' \\
\hline C3T-5 & 12 & 15 deọ. & $16^{1}$ & $2 ! !$ & 10 lbs. & $5 \$ .00$ & 100.00 & $30^{\circ}$ \\
\hline C97 & 18 & 15 deg. & $18^{\circ}$ & $2 \vdots 1$ & 12 ibs. & 83.00 & 05.90 & $3 !$ \\
\hline$C 3 \%-7$ & 12 & 75 deg. & 161 & $34^{\prime}$ & 12 las. & $\$ ! .00$ & 115.00 & $10^{\circ}$ \\
\hline
\end{tabular}

\section{CUSTOM CONB BOTTOM TANKS}

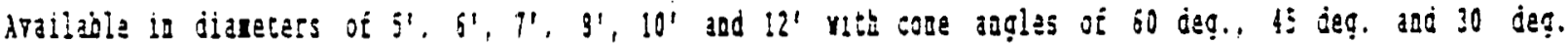

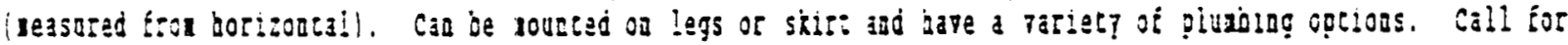
s.zlog pric:ag inforatation.

\begin{tabular}{|c|c|c|c|c|c|c|c|}
\hline \multirow[b]{2}{*}{10036} & \multirow[b]{2}{*}{ OUSIDS ? } & \multicolumn{5}{|c|}{ CIRCULAR RACEWAY TANR } & \multirow[b]{2}{*}{ PRIC3 } \\
\hline & & oIl. & EKSIDS JHA. & nDTR & DS2TE & CIPACITY I GALLOYSI & \\
\hline \multirow[t]{2}{*}{$639-1$} & $20^{\prime}$ & & $i 2^{\prime}$ & $4^{1}$ & $i^{\prime}$ & 1.500 & $\$ 3.100 .00$ \\
\hline & \multicolumn{7}{|c|}{ DBMAND FISH FEBDBRS * } \\
\hline YoDBL & arkeIt! & (i) $3 X 2300 B D$ & 0 IIBOSI & CORI AYGLI & DIA. & arIGa? & P2IC? \\
\hline $0 ! !-!$ & & 45 ibs. & & 45 deg. & $16^{3}$ & $34^{2}$ & 879.00 \\
\hline $\begin{array}{l}3 r !-i \\
07 !-3\end{array}$ & & $\begin{array}{ll}120 & \mathrm{bs} . \\
\text { to } & \mathrm{lbs} .\end{array}$ & & $\begin{array}{l}45 \text { deg. } \\
45 \text { deg. }\end{array}$ & $\begin{array}{l}2 ! ! \\
18 !\end{array}$ & $\begin{array}{l}963 \\
252\end{array}$ & $\begin{array}{r}115.00 \\
89.00\end{array}$ \\
\hline
\end{tabular}

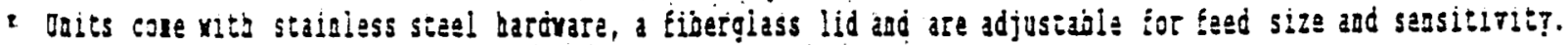

MODIFIBD NICHOLSON EEBDER: (FOr live brine shrimp, rotifers, algae)

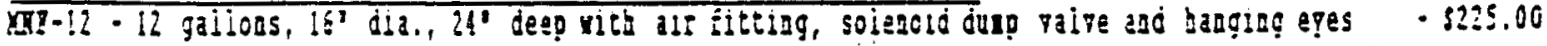

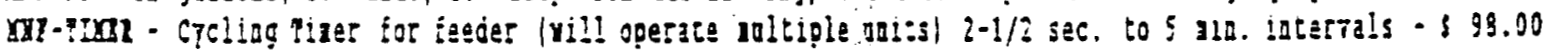

\begin{tabular}{|c|c|c|c|}
\hline \multirow[b]{2}{*}{$\underline{Y 00 B L}$} & \multicolumn{3}{|c|}{ AIRSTONBS (SILICA SAND WITH $100 \mathrm{MICRON} \mathrm{PORES)}$} \\
\hline & SIII & II:TETG & PrICs \\
\hline $10 \mathrm{AS} \cdot 105$ & $1-: 12^{1}: 1=1 / 2^{2}: 1-1 / 2^{1}$ & $3 / 10^{1} \exists$ & 32.35 \\
\hline AQAS-3 & $1-1 / 2+\geq 1-1 / 2^{\prime} \geq ?^{1}$ & $1 / !^{\prime} \equiv$ & 3.45 \\
\hline IQRS-F & $1-1 / 2^{\prime} \geq 1-1 / 2 \times 8^{1}$ & !/!' $\mathbb{3}$ & $\$ .15$ \\
\hline AQ1S-12 & $1 \cdot 1 / 2^{\prime} \geq 1-1 / 2^{\prime} \geq 12^{\prime}$ & $3 / 8 \cdot \sqrt{3}$ & 9.90 \\
\hline
\end{tabular}




\begin{tabular}{|c|c|c|c|}
\hline Ve:-i: & הa:- & יה:ב: & 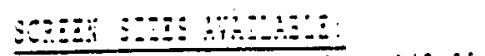 \\
\hline Xes:- & 5 & & 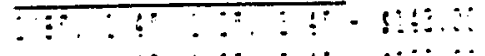 \\
\hline $3 x \leq-:$ & $\vdots$ & $\because:$ & 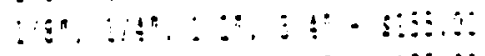 \\
\hline ?wos-! & ?! & : & 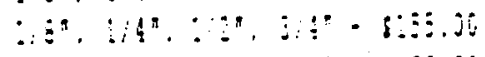 \\
\hline$?$ & ?' & $:^{\prime}$ & 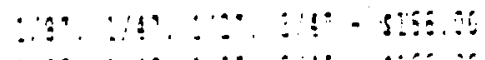 \\
\hline ins-: & $10^{\circ}$ & $\because$ & 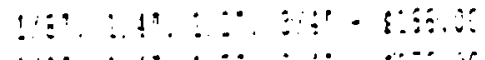 \\
\hline 30 & $10^{\circ}$ & $::$ & 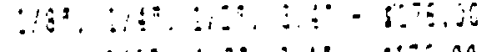 \\
\hline 3 YOS - & $g^{\prime}$ & $!$ & 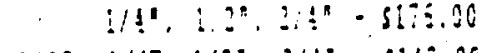 \\
\hline $3405-8$ & $\ell^{\prime}$ & : & $: 18^{\circ}, 1 / 4^{7}, 1 / 27,3 / !^{\prime}-8143.00$ \\
\hline 3 YNS -9 & $!$ & !: & $: / 4^{n},: i 2^{\circ},: !^{\prime \prime}$ \\
\hline
\end{tabular}

TANR FITTINGS

1. ?YC zLOXBIYG SITs ! include sxs elbor gilassed to sortor of audi. stand plpe and streanl.

\begin{tabular}{|c|c|c|}
\hline yon?. & 5125 & $9 ?$ \\
\hline ?WC-3:=? & $2^{\prime}$ & 85. \\
\hline ?UC-zit? & '" & 90. \\
\hline ?VC-Tㄷ 1 & $! "$ & $\because 35$. \\
\hline
\end{tabular}

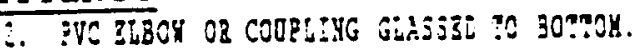

\begin{tabular}{|c|c|c|}
\hline Y00IL & SI:E & zeict \\
\hline$\overline{8 C-3 !:}$ & $\because "$ & $3: 2.98$ \\
\hline TYS-II : & !" & 30.30 \\
\hline : :7c-8! & $!$ & $\$ 0.10$ \\
\hline 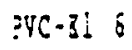 & $g^{\prime}$ & $\vdots$ \\
\hline : & בְ" & : \\
\hline
\end{tabular}

POLYESTER FILTER MATERIAL

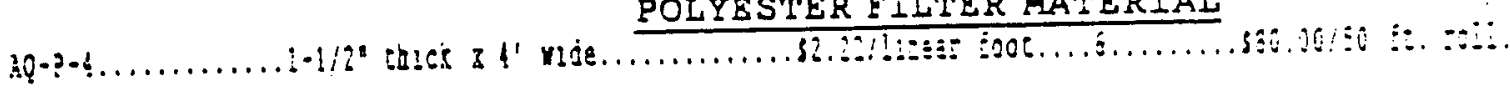

\begin{tabular}{|c|c|c|c|}
\hline & IHSIDE oIMUY?? & 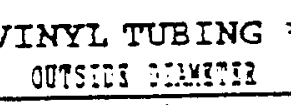 & 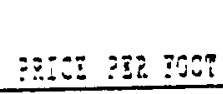 \\
\hline $30-19640$ & i!!" & $9 / 81$ & S.i! \\
\hline $2 Q-1 P 5+1$ & $3 / 8^{1}$ & $1 / 6^{\prime}$ & $\therefore ?$ \\
\hline$\lambda Q-195 \leq 2$ & $1 / 2^{\prime}$ & $5 / 81$ & .21 \\
\hline $10-18512$ & $j / 81$ & $3 / !$ & .26 \\
\hline $2 Q-7 t-007$ & $3 / 1^{\prime}$ & $1^{\circ}$ & .95 \\
\hline $10-8 m-1$ & $I^{\prime}$ & $! \cdot ! ! ! !$ & $\therefore .20$ \\
\hline
\end{tabular}

* Discoures arailabie or 100' iolls.

PINCH CLAMPS FOR VINYL TUBING

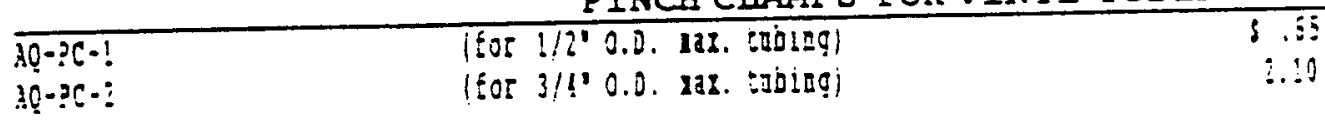

\begin{tabular}{|c|c|c|c|}
\hline & YISA SIZI & $\begin{array}{l}\text { TIC } \\
\text { MnTS }\end{array}$ & 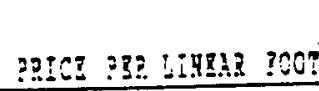 \\
\hline$\overline{1 Q-41 / 8}$ & $1 / 8^{1}$ & $39^{1}$ & $\delta .5 !$ \\
\hline$A 0-31 / 4$ & $1 / 41$ & !g! & $: .29$ \\
\hline$x 0-31 / 2$ & $1 / 2^{\prime}$ & $18^{2}$ & 1.32 \\
\hline $20-13 / 4$ & $3 / 4^{\prime}$ & 181 & 1.30 \\
\hline
\end{tabular}

* Discourts arailahle on rolls of $100^{\prime}$ or 205 .

\begin{tabular}{|c|c|c|c|c|}
\hline \multirow[b]{2}{*}{ Yoosu } & \multirow[b]{2}{*}{ GuLORS } & \multicolumn{3}{|c|}{ * STACK TANRS FOR WATBR STORAGB } \\
\hline & & DIAXIPIL & EIIGE! |YITE LIDI & ??IC! \\
\hline $59-500+$ & 500 & 52 & $12^{\prime}$ & $8: 95.30$ \\
\hline $5 ?-1000+$ & 1000 & $74^{\prime}$ & $12^{\prime}$ & 795.00 \\
\hline$\$ ? \cdot 1500$ & 1500 & 871 & 768 & $\$ .295 .00$ \\
\hline $57-2000$ & 2000 & 898 & $9 \xi^{8}$ & $\$ .29 \$ .00$ \\
\hline $57-3000$ & 3000 & 1061 & $1000^{\circ}$ & $\$ .495 .00$ \\
\hline
\end{tabular}

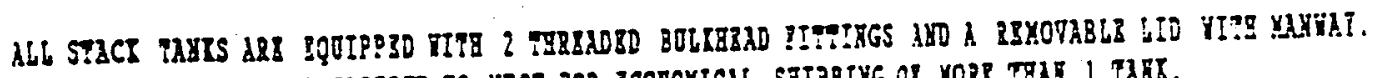

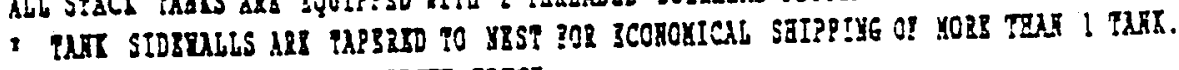

+ CU 31 SIIPPBD yotOR IRIIGAT iROCX. 


\begin{tabular}{|c|c|c|}
\hline :3: & 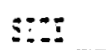 & : \\
\hline 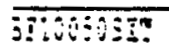 & $i ; 3$ & $\overline{s i .2}$ \\
\hline 3!!00?:31"? & $\vdots ! !$ & 8.30 \\
\hline & $\vdots^{\prime}$ & $\vdots \vdots \vdots$ \\
\hline 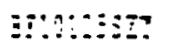 & $\vdots-\because: !$ & $\because .: 3$ \\
\hline 37:ง1:0:1T & $1 \cdot::=$ & $\because .: 8$ \\
\hline $3 ?: 0: 00 \leq I 7$ & ?' & 18.50 \\
\hline $3 \div 1030051 \%$ & $: 1$ & 34.90 \\
\hline 1040055: & $4^{\prime}$ & $\$ 7$ \\
\hline
\end{tabular}

\begin{tabular}{|c|c|c|}
\hline :1: so & : : & 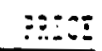 \\
\hline 690050 & $1:$ & 85 \\
\hline $9171009 \vdots$ & $2 ! \div$ & \\
\hline $87 ! 2 ! 00$ & $\vdots^{1}$ & \\
\hline 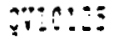 & $\therefore \because !:$ & \\
\hline 90 & $\because \because \because$ & $\because \therefore$ \\
\hline 170290 & $\because:$ & \\
\hline
\end{tabular}

* also avaILABLE - INQUIRE ON SIZs AND PRICE.

* AVAILABLB WITH TXT OR SXS CONNECTIONS.

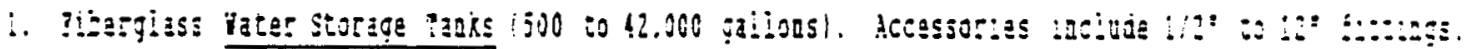

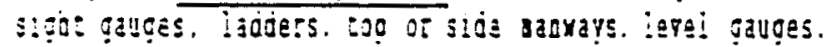

$\therefore$ lighoxars -

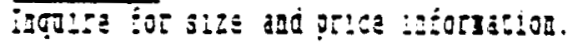

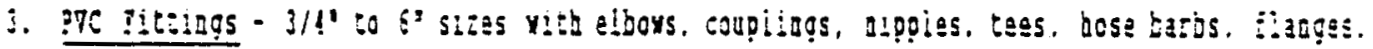

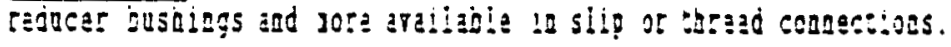

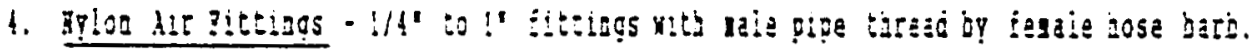

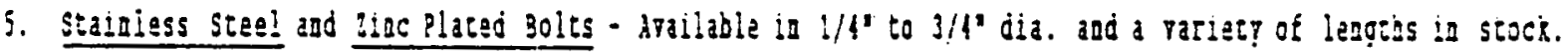

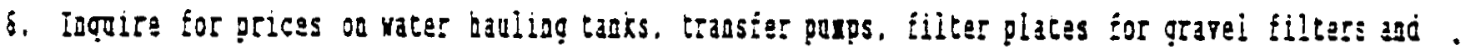
other bilier sateridl.

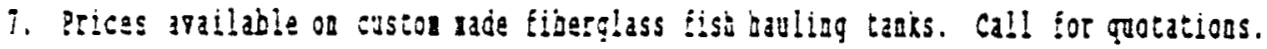

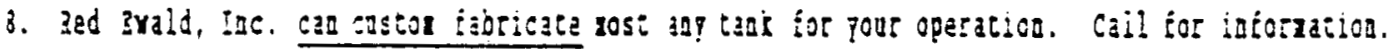

TFIS PRICE IIST REPLACES ALI OTHERS AS OF JULY 13, 1990. PRICES, MATERIALS AND/OR SPECIFICATIONS SUBJBCT TO CLANGE WITH OR HITHOUT NOTICB. WARRANTT ON TANKS LIMITBD TO REPAIR OR REPLACENENT OF TANKS ONLY. SHIPPING AND CRATING SRRVICES ARB CHARGED SBPARATELY. DISCOUNTS AVAIIABLE ON CBRTAIN ORDERS IN COMBINATION WITH NURBBR OF TANRS ORDBRED AND DOLLAR VALUB INVOLVBD.

RED BWALD INC.

P. O. BOX 519

RARNBS CITY, TY 78118

512-780-3304

1-800-531-3606 US 1-800-242-3524 TX

FAX: $512-780-4272$

TELEX: 767685 
RED EWALD, INC.

P.O. Box 519

Karnes City, TX 78118-0519

(512) $780 \cdot 3304$

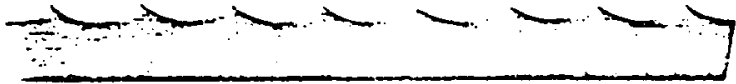

\section{BROODFISH SPAWNING TANKS}

Red Ewald, Inc. now manufactures tanks for broodfisi-spawning applications. These tanks were originally designed for and are being used in several redfish spawning applications. Its simple, functional design allows for use in spawning or holding applications.

This tank is a $12^{\prime}$ diameter by $5^{\prime}$ overall height fiberglass lank. This hign quality tanx comes in two (2) pieces, has a smooth molded gel-coat inish inside, has a built-in skirt and a sloped bottom. The 2-piece construction allows for legal load transportation and a smalier access door in your building.

The sloped bottom has several distinct advantages over a flat bottomed tank. The sloped bottom allows complete drainage for cleaning and aids in carrying debris during usage to a center standpipe. In handling fish, especially large broodfisin, draining the tank down a few incines aoove the

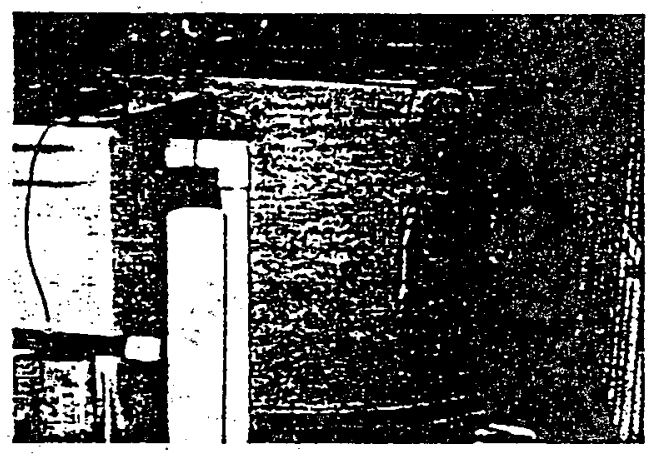
sloped area leaves the fish in the bottom center where they are easily caotured and cannot hurt themselves banging into the sicewalls

Also availaole is a $12^{\prime} \times 5^{\prime}$ deeo panel tank. This cost eificient tank is made up of five (5) side panels and a onepiece bottom allowing the tank to be carried through a standard 3' doorway and assembled inside.

Both tanks come complete with stainjess steel bolts and fiberglass materials for field assemoly.
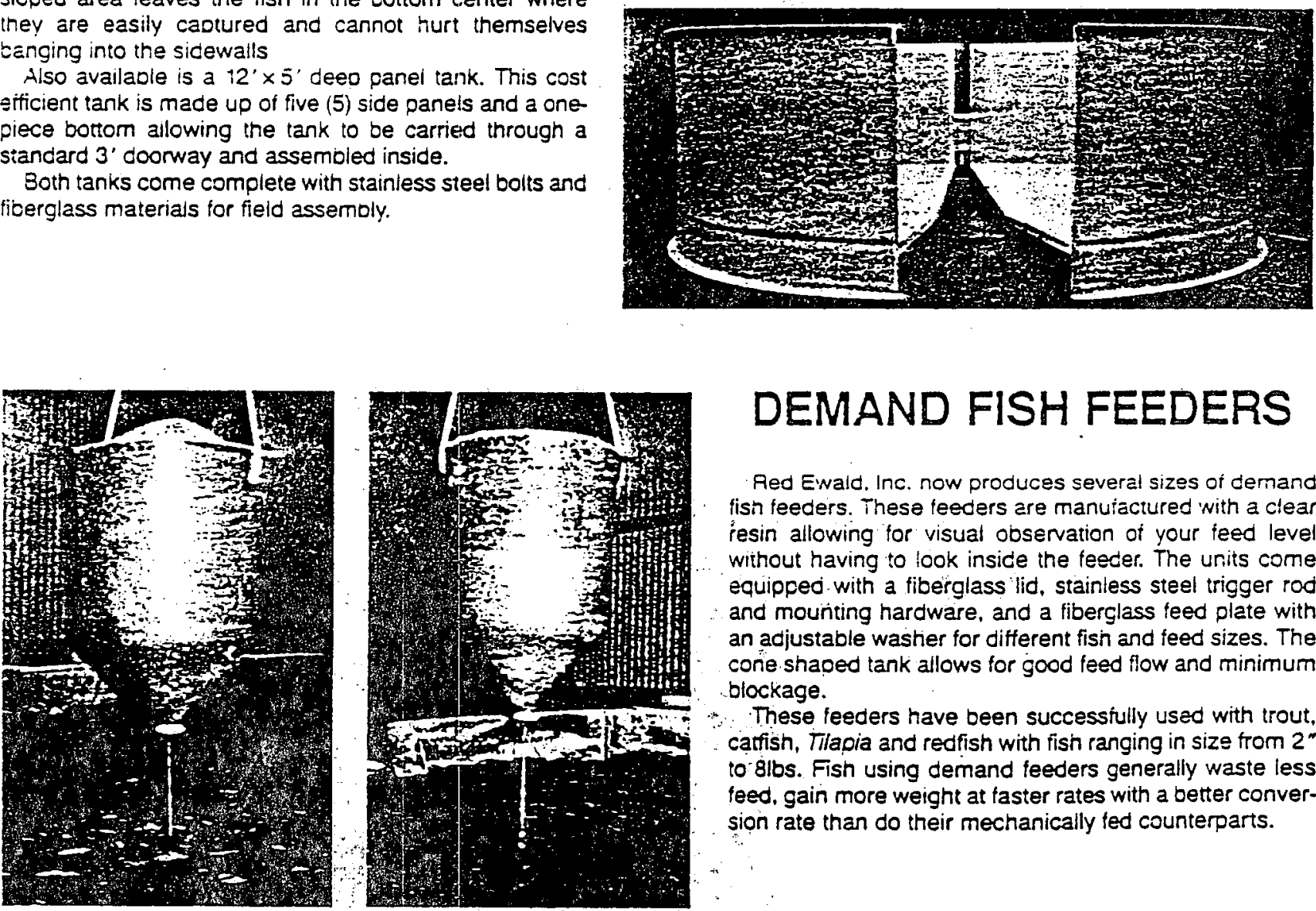

\section{DEMAND FISH FEEDERS}

Red Ewald. Inc. now produces several sizes of dernand fist feeders. These feeders are manuiactured with a clear pesin allowing for visual observation of your feed level without having to look insice the feeder. The units come equipped with a fiberglass lid, staintess steel trigger rod and mounting hardware, and a fiberclass feed plate with an adjustable wastier for different fisin and feed sizes. The cone shaped tank allows for good feed flow and minimum blockage.

These feeders have been successiully used with trout, caffish, Tilabia and redfish with fish ranging in size from 2" to 8 lbs. Fish using demand feeders generally waste less feed. gain more weight at faster rates with a better conversion rate than do their mechanically fed counterparts.

\section{"A NOTE ABOUT ALL RED EWALD, INC. AQUACULTURE TANKS"}

All Red Ewald fish culture tanks are manufactured using top quality materials and all our resins and gel coats are FDA approved for food grade use, and are therefore, saje for your fisn or snrimp. Our company has been in business for twenty-five (25) years and with it's experienced personnel, Red Ewald, Inc. has consistently manufactured quality products at comcetitive prices. 


\section{RED EWALD, INC. AND STELLMAN RANCH}

Rsd Evald. Inc. and Stellman Ranch have combined to design and construct a large indoor redfish hatenery-growout system for fincerling and iood fish production. This unique completely enclosed facility is one of the first of it's kind in the United States.

Instailed near Aransas Pass, Texas for access to saltwater, this facility will produce some $80,000 \mathrm{lbs}$. of food sized redfish ( $1 \mathrm{lb}$. plus) per year and sell excess fin. gerings to other fish farmers. The Stellman redfish farm was designed by Red Ewald, Inc. personnel (inciuding proiessionally trained engineers and biologist) and was equipped with Red Ewald fish culture tanks.
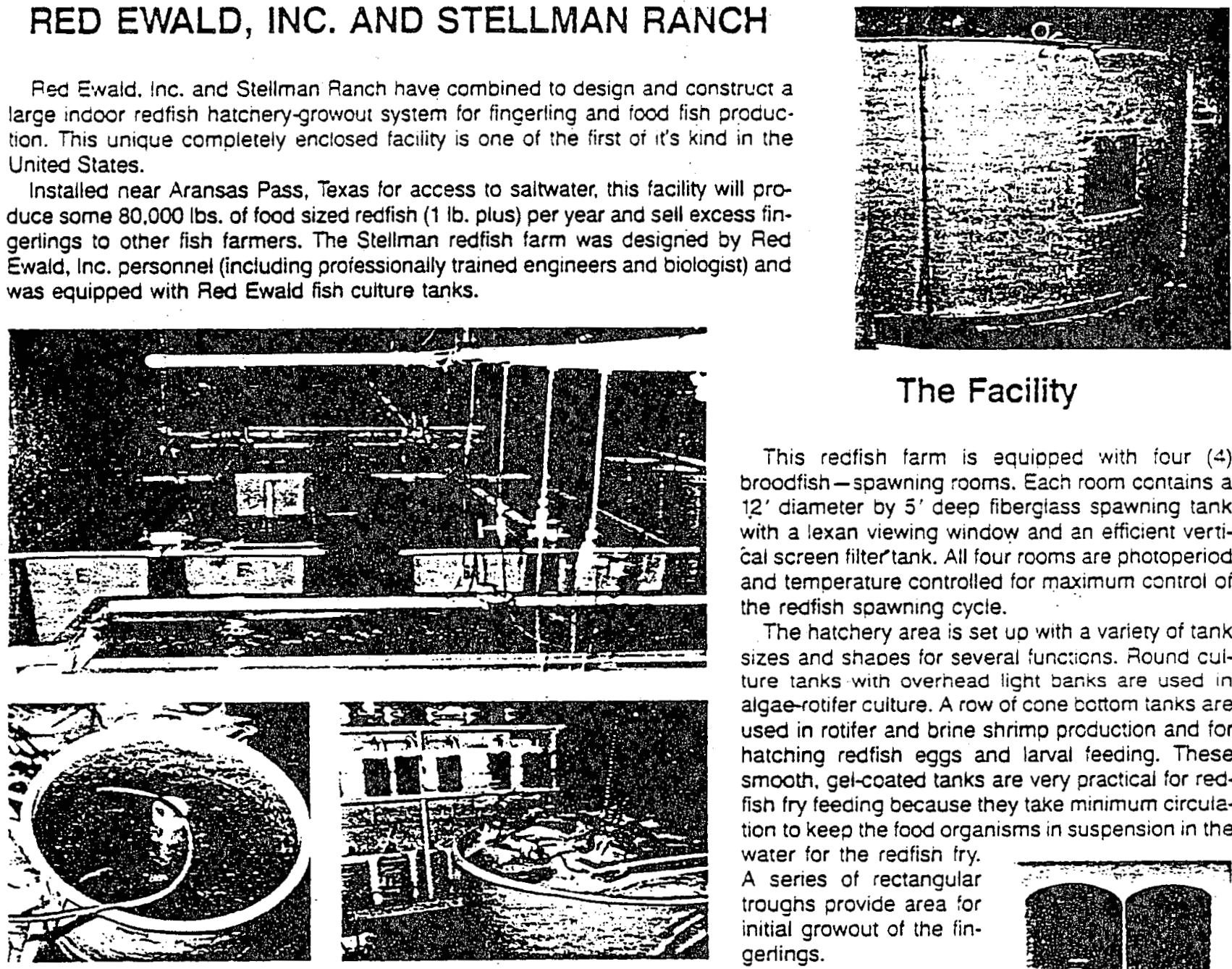

The Facility

This recisish farm is equioped with four (A) broodfish - spawning rooms. Each room contains a $12^{\prime}$ diameter by 5 ' deep fiberglass spawning tank with a lexan viewing window and an eificient vertical screen filter tank. Ail four rooms are photoperiod and temperature controlled for maximum control of the redfish spawning cycle.

The hatchery area is set uo with a variery of tank sizes and shaoes for several iunciicns. Round culture tanks with overhead light bariks are usad in algae-rotifer culture. A row of cone cottom tanks are used in rotifer and brine shrimp procuction and for hatching redfish eggs and larval ieeding. These smooth, gel-coated tanks are very practical for redfish fry feeding because they take minimum circulation to keep the food organisms in suspension in the water for the reofisin try. A series of rectangular troughs provide area for initial growout of the fingerlings.

The growout section consists of eight recirculating systems, each consisting of a 10.000 gallon Raceway and a $16^{\circ}$ Vertical Screen Filter. These tanks are capable of raising and supporting fish densities approaching $1 \mathrm{lb}$. per gallon.

The entire facility is powered by regenerative air blowers which provide air for aeration and water circulation. A backup generator provides standby electricity to prevent fish loss in the event of a power failure. Two (2) large water storage tanks provide fresh and salt water to the fish farm facility.
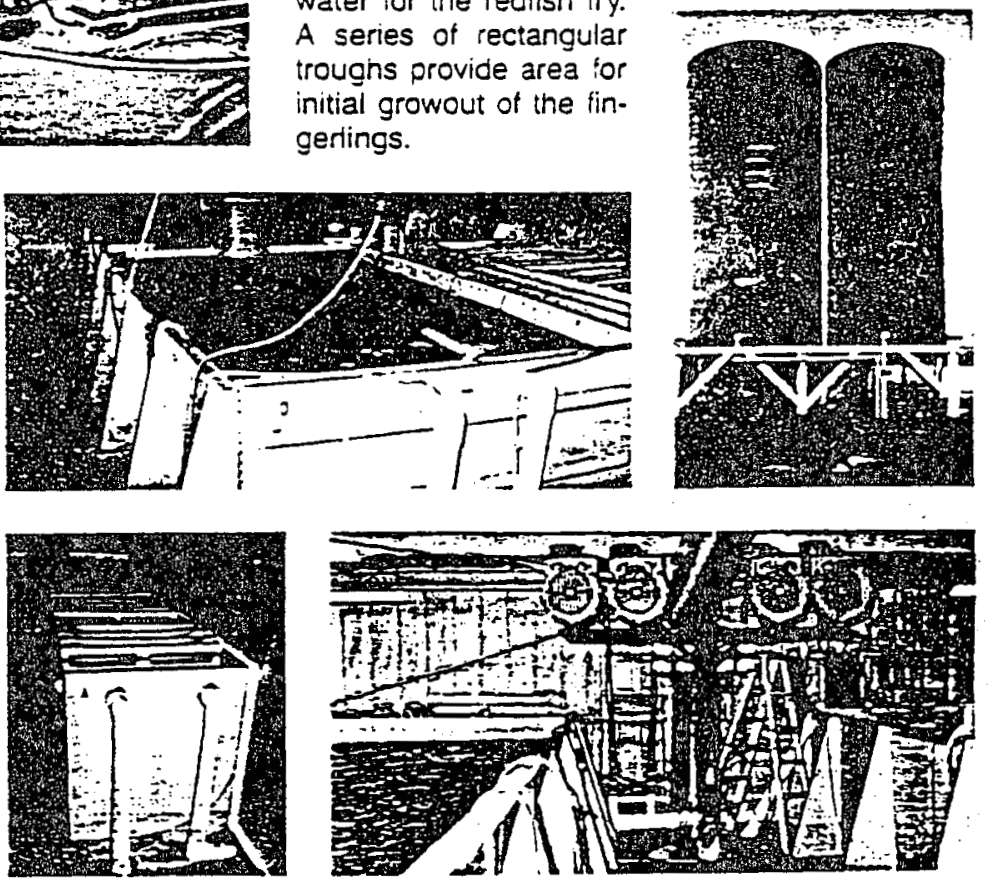

20. Box 519 Karnes City, TX T8t18-0519 Return Postage Guaranteed
Cail Toll Free $1.300-531-3606$

In Texas Call 1-800-2 42.3524

ielex TLX.757685 


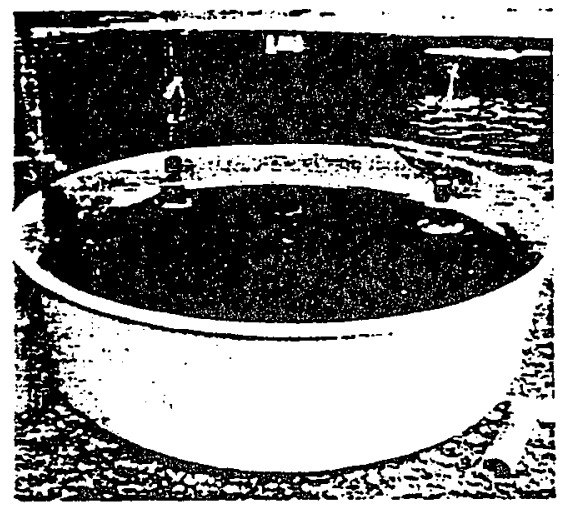

These round fish culture tanks are ideal for rearing fish due to their smooth gel coated interior. Tanks are available in many sizes up to $8^{\prime}$ in diameter to fill the needs of any size operation. These tanks are economical to build, yet are strong enough for years of dependable service. A reinforced tcp lip gives the tan $x$ addi. tional strength. The tanks are nested for shipping, giving you a tremendous freight savings.

These tanks are commonly used for fingerting growout, isolation of individual or small groups of fish. iemporary holding tanks, and are used in both snrimp and algae culture. They may be adopted to many otner uses depending upon your overation.

Many extras are availaole to include a variety of PVC drain fittings. PVC stand pioe plumbing kits. and fiberglass skirts which allow the bottoms of the tanks to

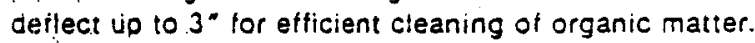
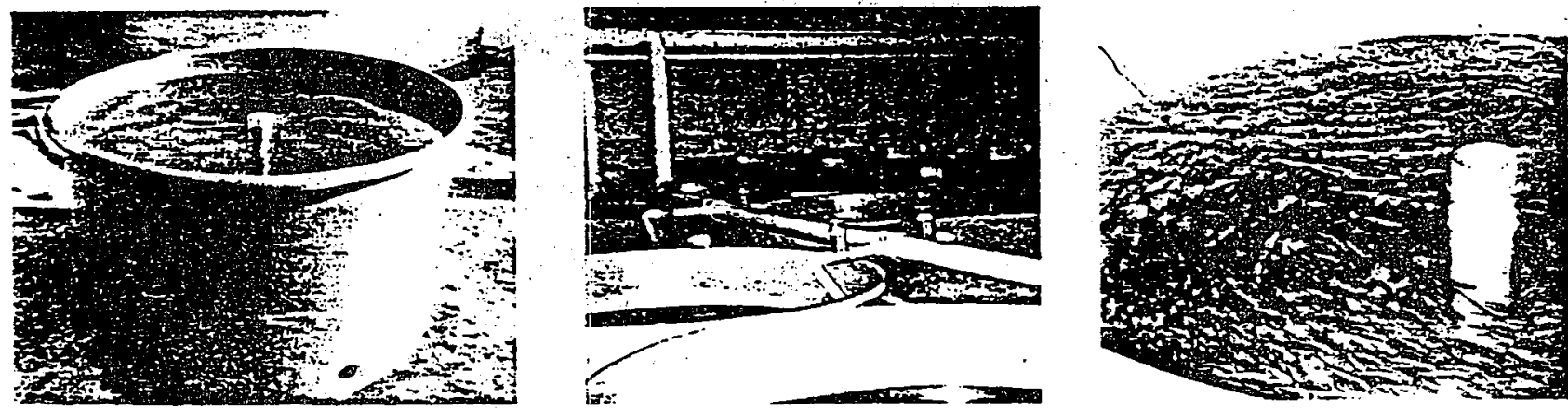

\section{Panel Tanks}

These large diameter tanks are iceal for fish raising. The $10^{\prime}, 12^{\prime}, 20^{\prime}, 30^{\prime}$, anc $40^{\circ}$ diameter anks are avariable in $24^{\circ}, 36^{\circ}, 48^{\circ}$, and $60^{\circ}$ heignts. This design allows these tanks to be sinicped in a package of several side paneis and a one piece corom. allowing us to snio a large quantity on a truck load for a tremendous freignt savinçs. The floor ano paneis are bolted together in the field with stainless boits and the seams are çlassed. forming a içic one prece iank. All bolts. nuts, washers, and fitergiass materials are turnished with the thit. After field assemoly, the tanks become a permanent one piece tank bü can be recut at the seams. taken apart. transported, and reassembled at a new location.

This tank is commonly used with a self-eleaning stand-pipe kit which allows ior an automatic cleaning of waste materials in the tank. The panel tarik is ideal where a large volume tank is needed inside an existing building with a limited size entrance. The sections and floor can be moved through a standard door and assembled inside.
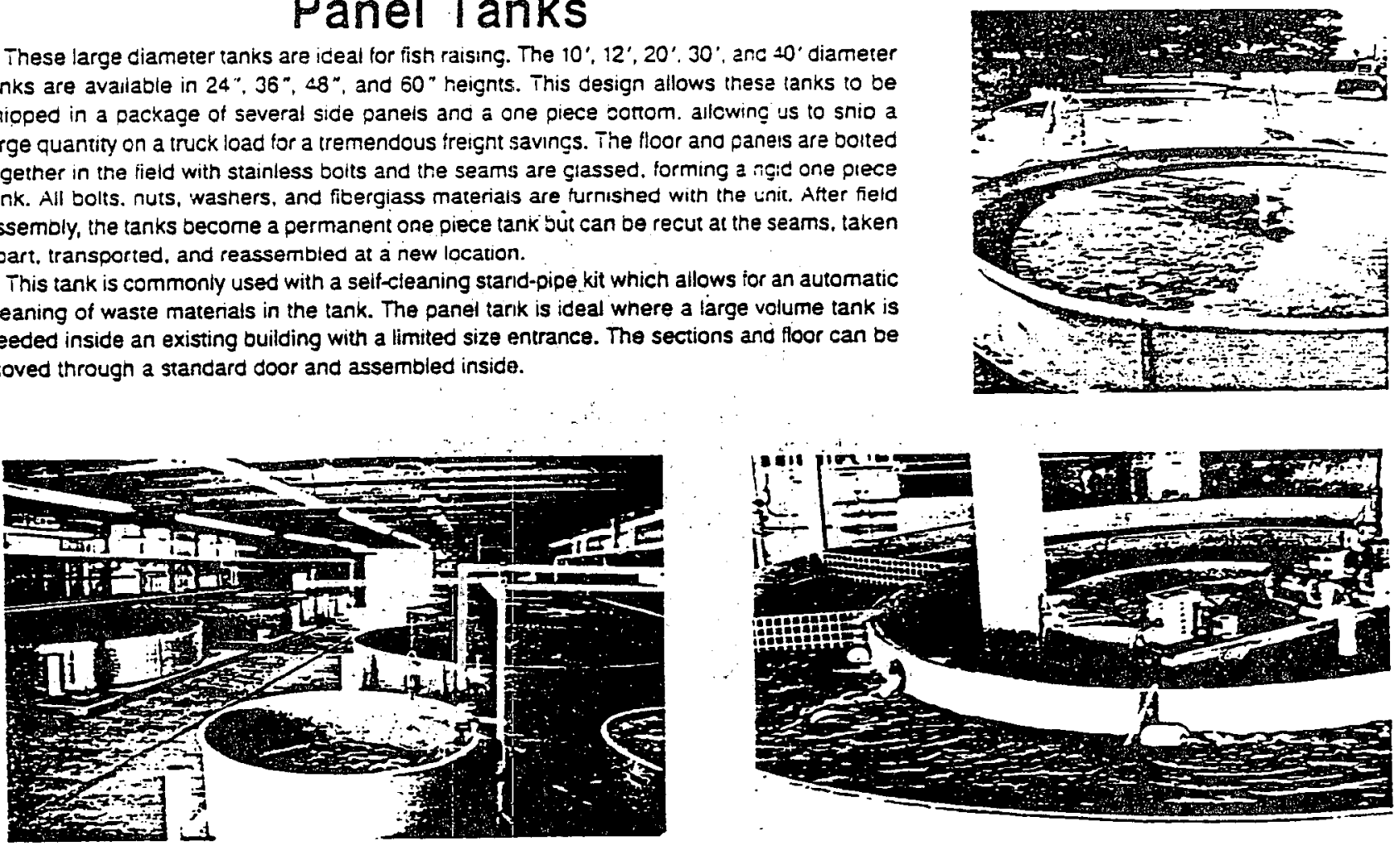
RED EWALD, INC.

P.O. Box 519

Karnes City, TX 78118-0519

(512) $780-3304$

(512) $780-4272$ (FAX)
RED EWALD, INC.

:- . - . - N TX 1-800-242.3524

US $1-800-531-3606$

TLX 767685

\title{
Fish Culture Tanks
}

At Red Ewald Inc. we have been making fiberglass tanks since 1962 that have been used extensively as culture and crop tanks. We have a series of standard mold tanks, with a smooth gel coated interior, that serve the needs of most enterprises. In addition, we can build tanks to the customer's needs.
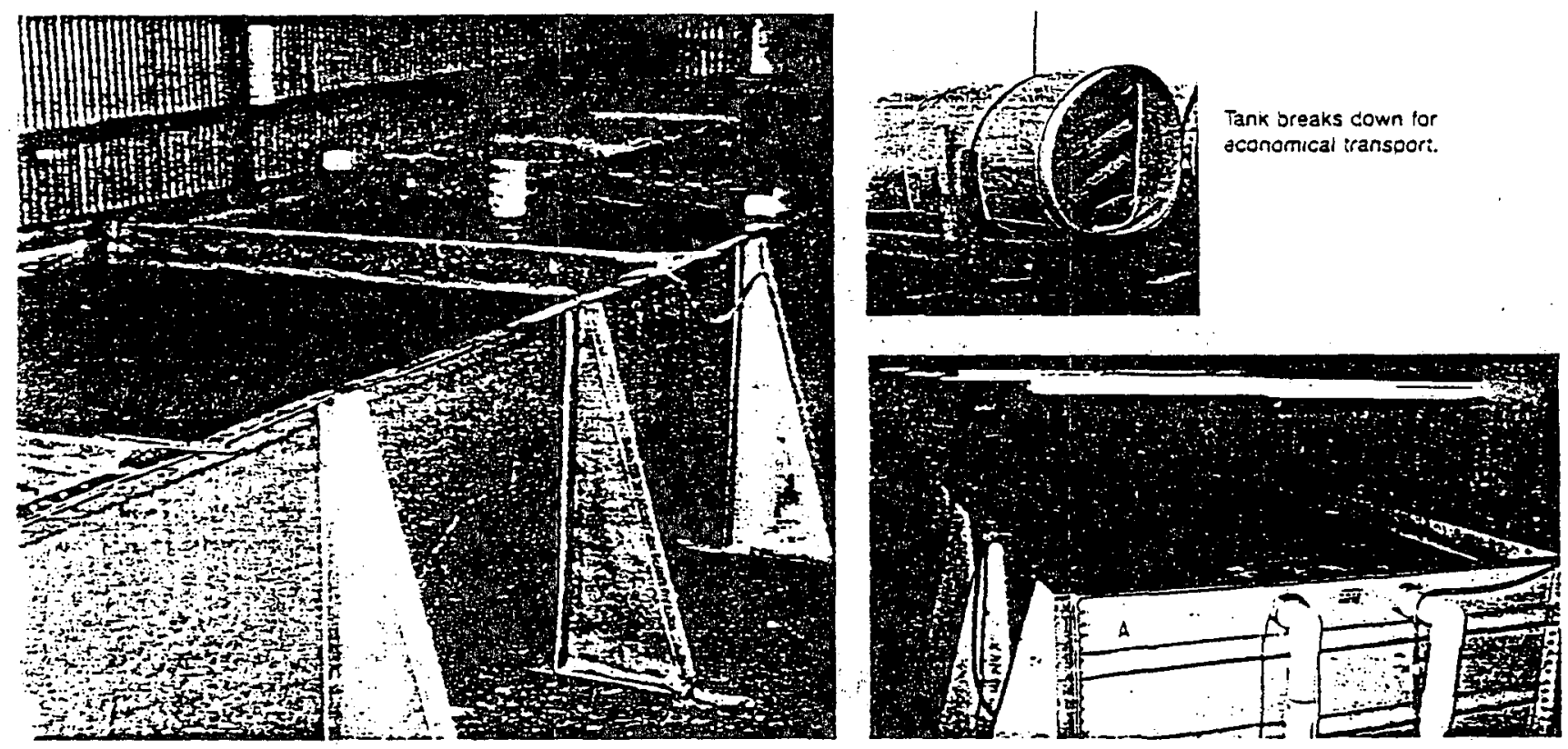

\section{Fiberglass Raceway Tanks}

\author{
U.S. Patent No. $+.244 .280^{\circ}$
}

The New Red Ewald Fiberglass "Raceway" Tank is unique in design and has several outstanding leatures and applications over other design tanks. The tank is constnucted entirely of fiberglass which offers the advantages of light weight, no rusting or corrosion proolems. Hextbility, exceptional strength, can te easily moved. . aitered or reoaired. and requires no painting.

The tank's sidewails and bottom are formed from a single. continuous, flexible. fiberglass sheet having a smooth interior finish without seams, offsets, or joints. The tank maintains its U-shace merely by virtue of its connection to the two ends of the tank and its support by struts aiong both side which contorm to the tanks sidewalls. The struts are arranged in oppositely facing pairs along the sides of the tank and are connected by a fiberglass strip underneath the tank. The struts are not attached to the sidewail or bottom of the tank and may be claced at any desired location along the botrom and side edges fermitting the botts to extend througn parts of the tank which are not exposed to the tank's contents thus avoiding possible corrosion and contamination proolems and also leaving the interior of the tank smooth. Ficerglass angles are bolted to the top of both sides of the tank to prevent the sicewails of the tank from bowing outward. The unique design, eliminates top cross braces. which is especially important in the fish culture industry where an open span tank is desirable to faciitate the use oi dio nets. strainers, and separators.

The tank is cesigned to completely break down for economical transoonation. The sides and floor are formed with one flexible fiberglass sneet. This sneet can be rolled up into a $3^{\prime}$ to 5 ' (depending on tank size) diameter roll for shipping. The struts nest inside each other and can be shipoed along with the ends, support angles, boits, gaskets. and options inside the rolled sheet. No additional fiberglass materials or sicecial tools are required.

This design tank has been used successtully for many years and has given our customers excellent service. Raceways are commonly used in fish and sinimp growcut. for high density culture, and offer more control in cutture operations than does the older pond method. This cesign is eseecially cesirable where a limited amount of space is avaliable, sucin as inside a building.

\section{Quality Pride - Experience}




\section{Recirculating Culture Systems}

Fed Exald, Inc. can design and manufacture recircuiating culture sysiems to fit your acuaculture operation. These systems can be designed tor broocfish soawning, larvai rearing, hign cerisity growout for fingertinģs and tood isin, live nolding systerns ard more. Many scecies of fisn. shrimp and other snelffisn are ceing useo in Red E'vald Recirculating Systems.

These systems can be designed around raceways, panel tanks, smail troughs, round tanks and cone bcttom tanks and are used in conjunction with Red Ewald's erficient Vertical Screen Filter System (patent pending). Complete aeration and circulation capabilities can be built into system design.

\section{Filters}

Vertical Screen Filter System (patent pending)
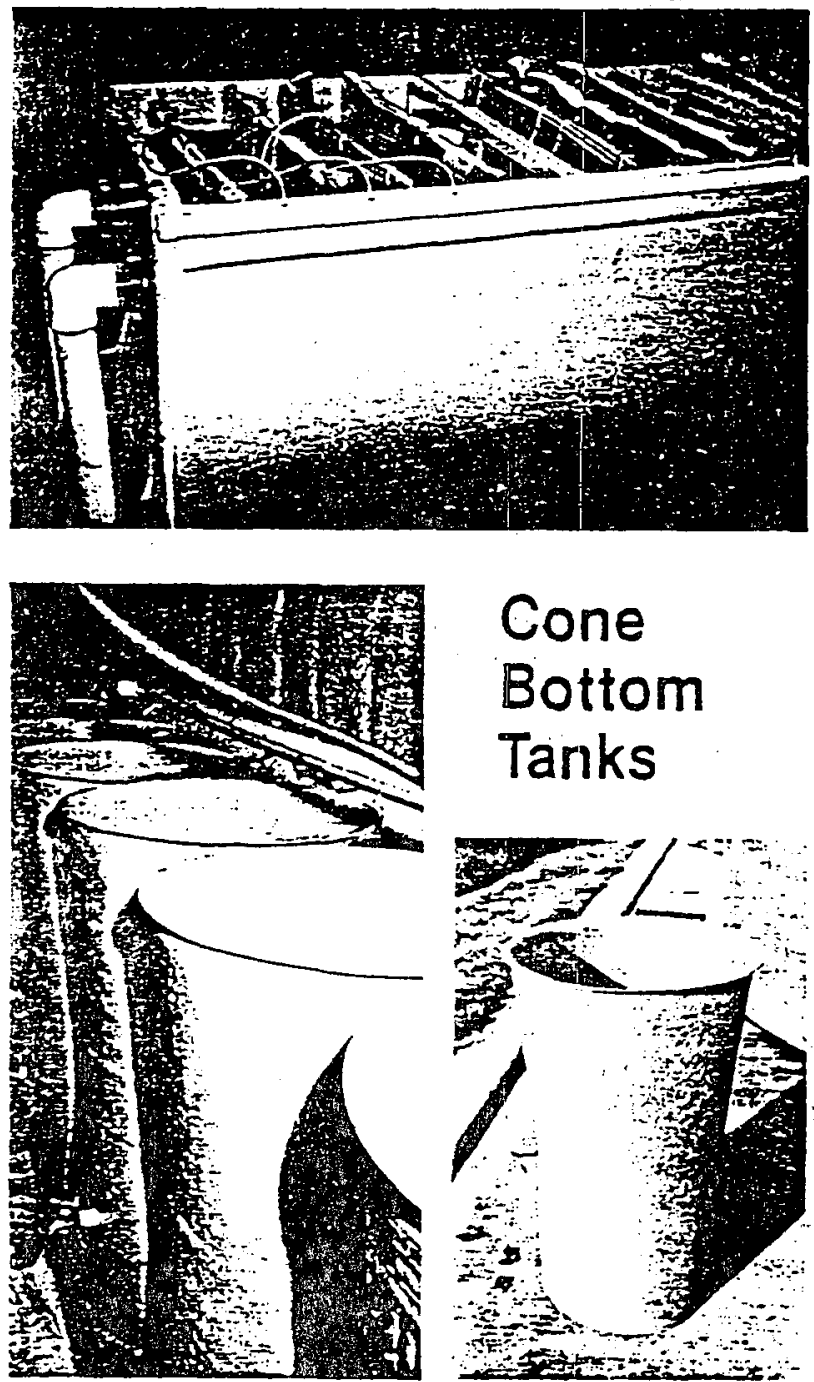

Cone Bottom Tanks

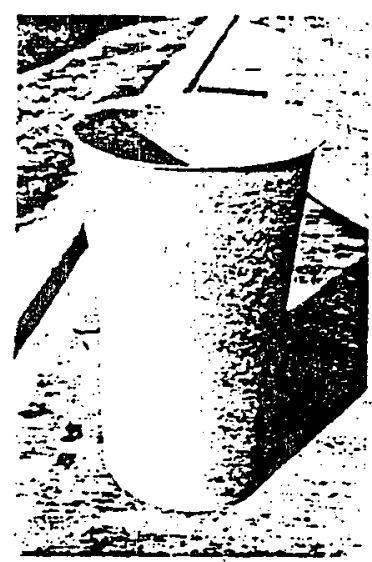

Cone cottom tanks are excellent for the rearing of saltwater and iresnwater shrimo. They are also commonty used to hatch red drum and other rish eggs and in larval rearing. Brine shrimp are hatched in cone bottom tanks. These tanks have a smooth molded, gel coated interior. Molded sizes are available from 12 to $\$ 00$ gallons and mandrel wound sizes are available $6^{\prime}$ to 12 ' in diameter with several cone angles and many sidewall ceoths. These larger sizes are very common in commercial snnmp operations as larval rearing :anks. All cone bertom lanks are availaole with legs or a fiberglass skirt. a reiniorced too lip. and with a variery of plumoing options.

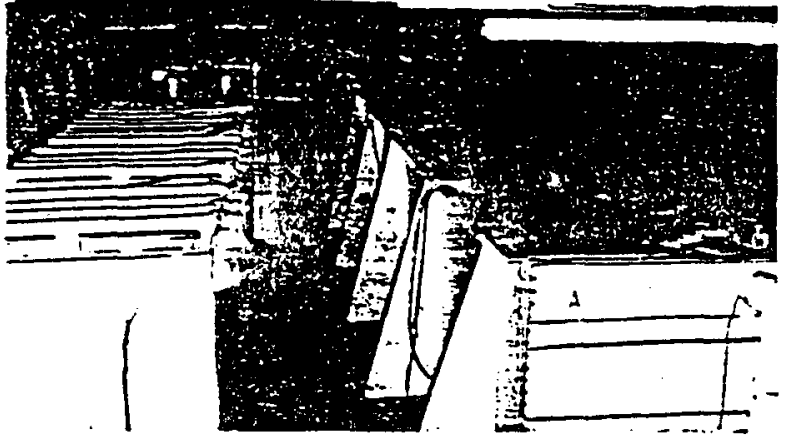

Red Ewaid, Inc. manufactures a line of filters for your aquaculture operation. These include the Vertical Screen Filter System (patent pending) and fiberglass plates for undergravel fitters. In $\mathrm{O}$ acdition, Red Ewald, Inc. can custom manufacture fitters and J tanks to customer specifications.

(b) The Vertical Screen Filter System (patent pending) is a complete filtration system utilizing a high density polyester sc:een that traos sediments and trash and provides maximum amounts of surtace area for bacterial grown and biological removal of ammonia, nitrites and other dissolved organics. By utilizing these screens in the vertical position, the entire water column is filtered with a minimum amount of floor space. The water passes horizontally through the sc:eens. Aeration increases the eificiency of the filter many times. The screens are easily removed and sorayed off with a hose if clogged. and all the screens have overilow oypass in case of clogging.

Fed Ewald now produces a series of filter plates for sandgravel type filters. These filter plates can be adapted to all our round and rectangular culture tanks to fit most any filtration need. Used in combination with $1 / 4 \times 1 / 6$ gravel. these filters provide for very efficient filtration of ammonia and other cissoived suostances. Various plumbing options are available including bacx flush hookups for deaning of the filter and aiflifts for increased filter efficiency.

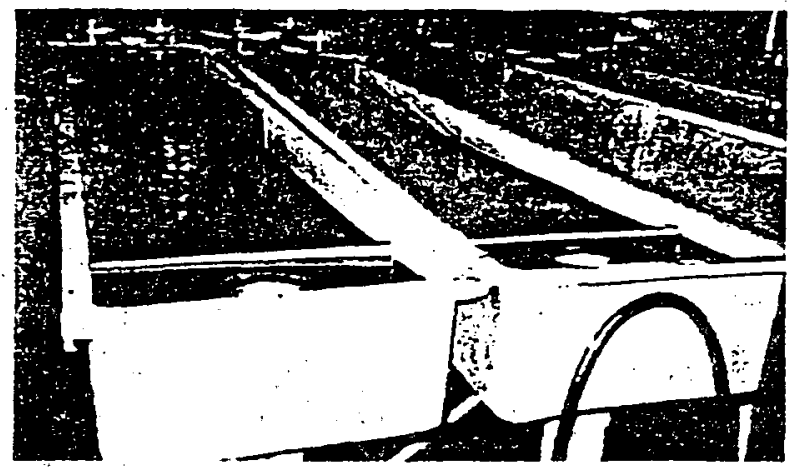

\section{Fish Rearing Troughs}

Rectangular fiberglass troughs are available in many sizes ranging trom $6^{*}$ to $36^{*}$ deep, $12^{*}$ to $60^{\circ}$ wide and $48^{\circ}$ to $216^{*}$ long. These troughs are fabricated on a waxed mold giving the interior a smooth mirror finish. A top lip for extra strength and curability is standard on ail tanks. A stiftener rib is standard on larger tanks to prevent cowing in the sidewails.

These troughs serve many needs in the culture business. These needs include uses in fisn fry growcut and as hoiding tanks in the crab and lobster industry.

Fish reaning troughs are very popular due to their high versatility. many avaulable sizes, and a variery of plumbing opnons. They are economically priced and are nested for a tremencous freignt savings. 


\section{PORTABLE MODULAR FISH HATCHERY SYSTEMS \\ (U.S. PATENT $\$ 4,738.220$ )}

Red Exald. Inc. manufactures a series of portable modular fish hatchery and lab systems. Utilizing insulated trailer vans, inese trailer systems are easily moved from one location to another. In the event of aonormally high tices and storms, ihe trallers can ce moved to high ground and safery until the danger is past.

These Modular Systems can be designed to facilitate broodfish spawning, hatching and rearing of larval fish and fingerlings. and live leed reaning (algae, rotiters, brine shrimp, nematodes). As a mobile wet lab, these modular systems can be used as an on-site laboratory for field studies and research. System designs can inciude recirculating or flow-through capabilities, heating and cooling capabilities, aeration, lighting and more. Units are currently being used with Tlapia, red drum. rotifers and algae, and as a mobile wet lab.

\section{FRY-FINGERLING-BRINE SHRIMP TRAILER}

The module is equipped with a senes of culture tanks for agg incusoation and hatcing, try rearing and fingerting culture with size and shape of the tanks depending upon the type of fish being cultured. This trailer can also be equipped with cone bottom tanks for brine shrmo culture. An air blower and heater-air conditioner are standard.

\section{BROODFISH TRAILEA}

The trailer includes two large incependent tanks for broodfish with filter lanks through which the water is recirculated. An air blower provides air for aeration and water circulation along with heating and cooling equioment for environmental control. Lighting is time clock controlled.

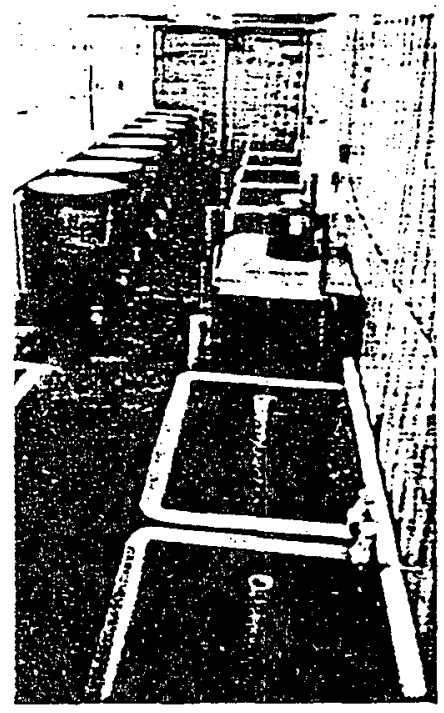

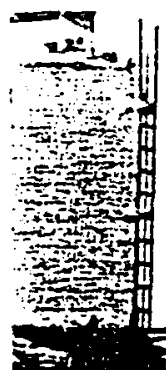

tas.

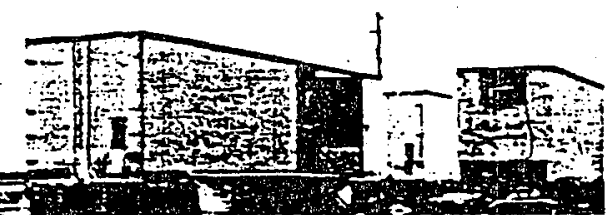

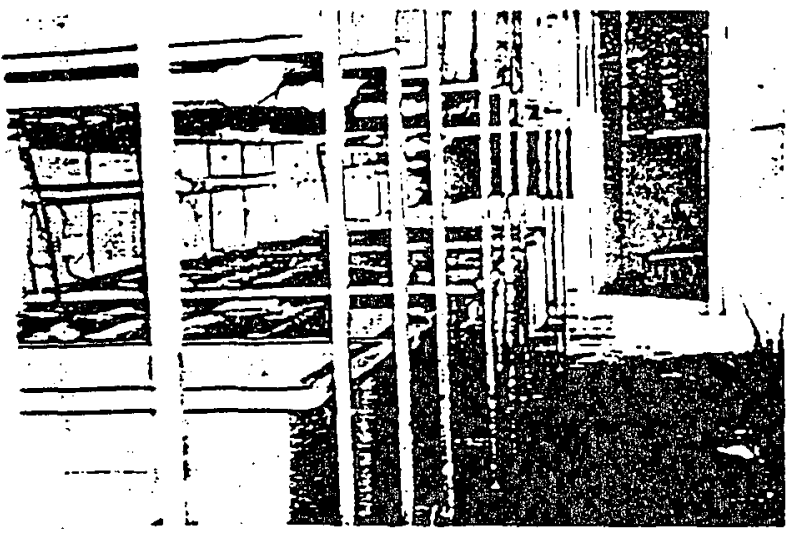

\section{MOBILE WET LAB}

This trailer option provides tanks and systems for researcn ano experimental stucies. Esuipoed with tanks, aeration. lighting, heaung and cooling equipment, a comclere work area can se ses up at remote sites or can have a permanent home base. These trailers are designed and built to customer specifications. All that is needed at each joosite is water and electricity. At remote sites. the trailer can be powered with a portable generator. One current trailer has been used is research work on sea urchins, craos. octooi, soiny looster and more.

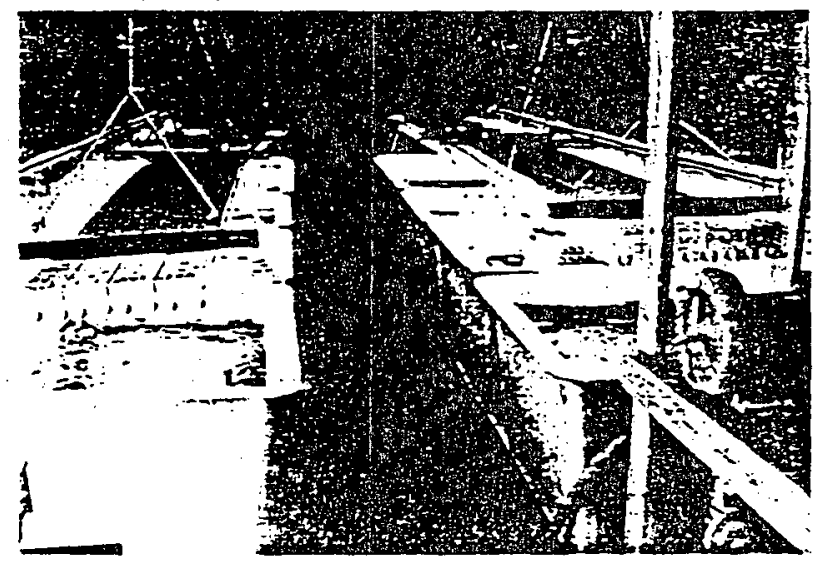

\section{ALGAE-ROTIFER TRAILER}

This module has a series of tanks for the culture of algae. rotiers, or other live food organisms used in fisn culture. An air blower provides aeration and a combination heater-air conditoner provides temperature control. Hign intensity light banks provide light for algae culture.

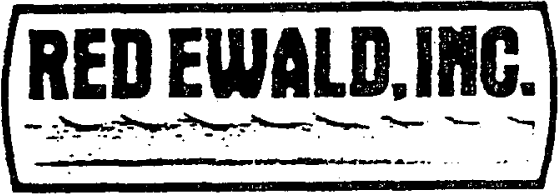

P.O. Box 519 Karnes City, TX 78118.0519 Return Postage Guaranteed
CALL TOLL FFEE

Nationwide 1-600-150-3341

U.S. $1-800-53 i-3606$

Texas $1-800-242.3524$

Telex TLX-767E25

FAX $512-780-272$
BULK AATE

U.S. POSTAGE

PAID

Xarnes City, ix iarib-is 19

Parmit NO. 
APPENDIX E

WATER WELL QUOTATION

(R. DUMARCY, B\&J WATER WELL SERVICES)

$E-1$ 
B \& J Water Well Service

419 East First Street

Kaplan, La. 70548

Eaton Industries

1240 Blalock

Suite 100

Houston, Texas 77055

Attention: Mr. Doug Graham

This well will be between 400 It. and 500 ft. deep.

The well will comply with the rules of the Department of Transportation and Development of Baton Rouge Ia.

The well will be cemented from the top of the water producing sand to ground surface.

The well will produce 600 G.P.M. with pressure setting of $30 \#$ - 50\# pressure.

The well will be connected to your wire at well site.

Sincerely,

Kay A Re M nary

$B$ \& $J$ Water Well Service

$R D: a I$

$E-3$ 
B \& J Water WelI Service

419 East First Street

Kaplan, Ia. 70548

Eaton Industries

Attention Mr. Doug Graham

This is a copy of what I quoted over the phone.

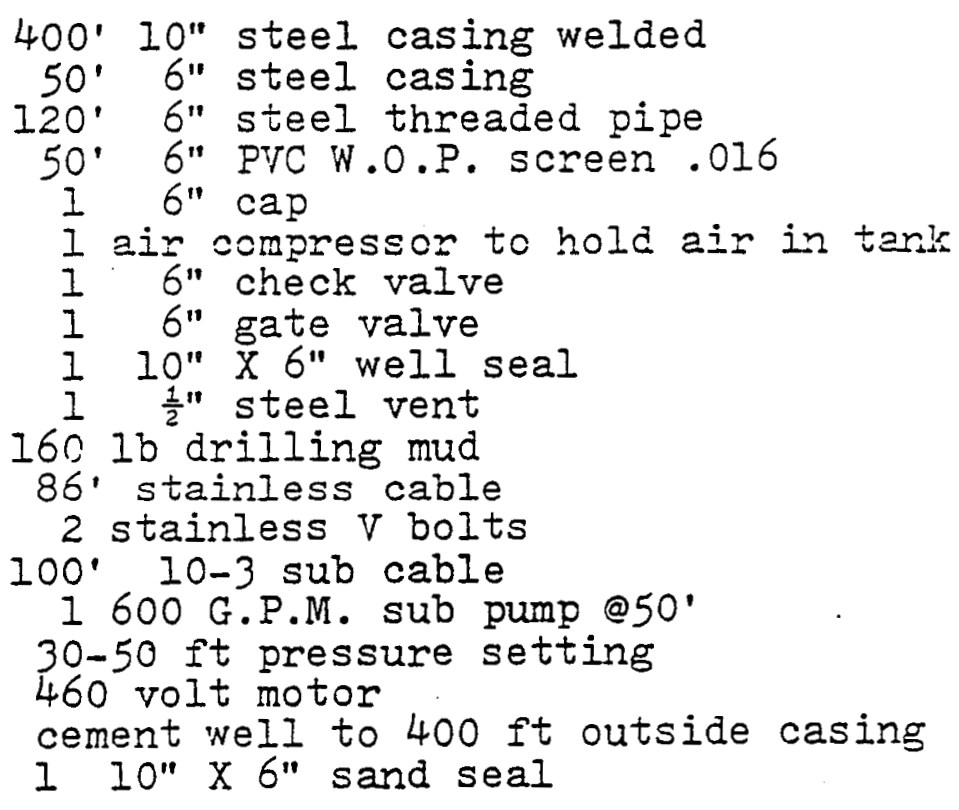

Cost of well $\$ 23,620.00$ Plus Tax

10,000 gal. Steel painted tank $\$ 13,482.00$ plus tax $\$ 2,000.00$ installation plus tax

10,000 gal. coded tank $\$ 20,436.00$ plus tax

Installation $\$ 2,000.00$ plus tax 


\section{APPENDIX $F$}

COMPARATIVE PERFORMANCE ANALYSIS: COMMERICAL CUT-FLOWER PRODUCTION (J. WHITTIER, SOUTHWEST TECHNOLOGY DEVELOPMENT INSTITUTE)

SEATTLE TIMES EDITORIAL 


\title{
COMPARATIVE PERFORMANCE ANALYSIS:
}

\section{COMMERCIAL CUT-FLOWER ROSE PRODUCTION}

\author{
Jack Whittier \\ Carol L. Fischer \\ Southwest Technology Development Institute \\ New Mexico State University \\ P. O. BOx 3SOL \\ Las Cruces, NM 88003 \\ Telephone 505-646-1846 \\ FAX 505-646-2960
}

April, 1990

The work from which this material is drawn was conducted with the support of the New Mexico Research and Development Institute and the U.S. Department of Commerce, Economic Development Administration. However, the authors remain solely responsible for the content of this material. 


\section{BIBLIOGRAPHIC DATA SHEET \\ for reports sponsored by \\ New Mexico Research and Development Institute \\ Santa Fe. New Mexico 87501}

\begin{tabular}{|c|l|l|}
\hline $\begin{array}{l}\text { 1. NiMRDI REPORT NO. } \\
2.78 .5202\end{array}$ & $\begin{array}{l}\text { 2. PUBLICATION DATE } \\
\text { ADril. } 1990\end{array}$ & $\begin{array}{l}\text { 3. NO. OF PAGES } \\
121\end{array}$ \\
\hline
\end{tabular}

4. TITLE AND SUBTITLE

Comoarative Performance Analysis: Commercial Cut-Flower Rose Production

5. AUTHOR(S)

Jack Whittier and Carol Fischer

6. NAME AND ADDRESS OF PERFORMING ORGANTZATION

Southwest Technology Development Institute

Box 30001, Deparment 3 SOL

Las Cruces. New Mexico 88003-0001

7. ABSTRACT

A comparative performance analysis has been conducted to examine the various factors associated with establishing and operating a commercial rose cut-flower greenhouse in ten different locations across the United States. Plant productivity, defined as net blooms producf " per plant per year, is largely dependent upon local climatic conditions and technological improvements. Regional variations in productivity have been explicitly aralyzed. The greenhouse operation is assumed to be four acres in size and the facilities utilize current technologies. The operation is designed as a professionally-organized company with an owner/manager, grower, and salesperson. The primary product is a red hybrid tea rose for sale at wholesale. Selling markets vary by location, but in general they are large metopolitan areas.

The analysis strongly indicates that new installations for cut-flower rose production are profitable in several areas in the U.S. Southwest, particularly in New Mexico, Arizona, and Texas. No one area stands out as a favored location. Las Cruces, New Mexico, has the highest net present value and return on investment results.

\section{KEY WORDS}

Economic analysis. commercial greenhouse. rose oroduction. feasibility. production costs.

9. AVAILABILITY

Copies of this repor are available from the New Mexico Research Development Institute, Communications Office, Suite M, 457 Washington SE, Albuquerque, NM 87108, (505) 277-3661. Please inquire as to price. 


\section{EXECUTIVE SUMMARY}

A comparative performance analysis has been conducted to examine the various factors associated with establishing and operating a commercial rose cut-flower greenhouse in ten different locations across the United States. The purpose of this study is to compile a consistent, unbiased, and meaningful comparison of commercial greenhouse industry costs, the variables affecting those costs, the implications of altering key variables, and the financial returns associated with the business operation. The results of this study will provide prospective business ventures with important data for planning and decision making.

The intent of the analysis is to examine various geographic regions within the United States to determine sites with greater profitability for a new business operation. Because profitability is greatly influenced by a wide diversity of competing factions, great care was taken to collect accurate information on each region. Plant productivity, defined as net blooms produced per plant per year, is largely dependent upon local climatic conditions and technological improvements. Regional variations in productivity have been explicitly analyzed.

In this report a hypothetical rose cut-flower operation is placed in ten geographic regions throughout the nation. The greenhouse operation is assumed to be four acres in size and the facilities utilize current technologies. The operation is designed as a professionally-organized company with an owner/manager, grower, and salesperson. The primary product is a red hybrid tea rose for sale at wholesale. Selling markets vary by location, but in general they are large metropolitan areas.

An economic model has been created to estimate various cash flow, financial, and profitability issues that are important to a greenhouse operation. It is assumed that a new greenhouse business venture is established at a new location, because the intent of the model is to compare the ten sites on a start-up basis. No allowance or consideration is made for existing greenhouse operations that may be associated with a business expansion in an already-established location. Estimates and assumptions were developed for the following items: greenhouse capital costs, economic 
factors, utility costs, cash flow, operating costs, and profitability. Each of these categories, among others, is fully discussed in Appendix A.

The selection criteria for the ten sites included the following considerations: presence or absence of an existing industry, market, climate, availability of pertinent data, and geographic diversity. The ten locations chosen for the study are: Tucson, Arizona; San Diego, California; Denver, Colorado; Boston, Massachusetts; Flint, Michigan; Kansas City, Missouri; Las Cruces, New Mexico; Columbus, Ohio; Scranton, Pennsylvania; and Dallas, Texas. The geographic diversity of the ten sites allows for the calculation of differing production levels, operating costs, and selling prices to help evaluate profitability in different regions.

The analysis strongly indicates that new installations for cut-flower rose production are profitable in several areas in the United States Southwest, particularly in New Mexico, Arizona, and Texas. No one area stands out as a favored location. Las Cruces, New Mexico, has the highest net present value and return on investment results. Two areas outside of the Southwest, Scranton, Pennsylvania, and Columbus, Ohio, also show a positive investment opportunity. Both of these areas are favored with low electricity rates that help reduce annual operating costs. Both Scranton and Columbus are vulnerable to electricity price increases to an extent not shared by the Southwest locations.

The level of uncertainty in critical assumptions precludes absolute statements of which location is the "best," or most profitable. A new firm will wish to carefully evaluate individual sites on a case-by-case basis before selecting a location. See Table la for a comparison of the various sites. 


\section{Table 1a. Comparative Financial Performance}

\begin{tabular}{|c|c|c|c|c|c|}
\hline Location & $\begin{array}{c}\text { NPV } \\
(\$)\end{array}$ & $\begin{array}{l}\text { ROI } \\
(\%)\end{array}$ & $\begin{array}{c}\text { BE Price } \\
\text { (S) }\end{array}$ & $\begin{array}{c}\text { Total } \\
\text { Sales } \\
\text { Revenue } \\
\left(\$ / \mathrm{ft}^{2}\right) \\
\end{array}$ & $\begin{array}{c}\text { Net Cash } \\
\text { Inflow }(A T) \\
\left(S / \mathrm{ft}^{2}\right)\end{array}$ \\
\hline Tucson & 218,991 & 8 & 0.27 & 6.43 & 1.00 \\
\hline San Diego & $-1,167,935$ & -1 & 0.32 & 6.00 & -0.09 \\
\hline Denver & $-391,875$ & 4 & 0.34 & 7.64 & 0.63 \\
\hline Boston & $-728,530$ & 3 & 0.47 & 9.38 & 0.54 \\
\hline Flint & $-575,487$ & 3 & 0.44 & 8.81 & 0.56 \\
\hline Kansas Cty & $-102,268$ & 5 & 0.37 & 7.88 & 0.86 \\
\hline Las Cruces & 352,470 & 9 & 0.27 & 6.60 & 1.09 \\
\hline Columbus & 218,204 & 7 & 0.39 & 8.44 & 1.17 \\
\hline Scranton & 286,600 & 6 & 0.41 & 8.81 & 1.05 \\
\hline Dallas & 282,942 & 8 & 0.30 & 6.56 & 1.00 \\
\hline
\end{tabular}

NPV - Net Present Value

$\mathrm{ROI}$ - Return on Investment

BE Price - Breakeven Selling Price

The reasons for estimated profitability for Southwest-based firms are varied, but they are directly attributable to one major operating factor that controls the industry. Greenhouse space represents a fixed production area. There are few options, within reason, for increasing annual production from the greenhouse floor area. High intensity discharge (H.I.D.) lighting is one accepted means for increasing production, but it is not readily feasible to plant more rose bushes per square foot or coax additional blooms from a plant. Because production is fixed, annual revenue is also similarly fixed. Bloom prices do not change dramatically, and no single producer within a region is able to receive substantially higher prices than another producer. Therefore the opportunities for increasing profitability come from lowering operating costs.

The Southwest offers, relative to the rest of the U.S., less expensive annual operating costs. Overall utility costs are low, land prices are competitive, and labor is both less expensive and available at the lower wage rates. Despite the situation that Midwest and East Coast growers are closer to the major markets and receive higher product prices than the Southwest growers, the lower operating costs in the Southwest offset the other regions' advantages.

The examples from Scranton and Columbus illustrate the precarious advantage of H.I.D. lighting. Both areas show estimated profitability, both with respect to the Southwest and to other domestic locations. The incentive 
afforded by low electricity rates allows for profitable operation of the H.I.D. lighting. However, slight increases in electricity rates, on the order of only S0.002-0.005/ kWh, dramatically shift profitability to a negative position.

Prospective growers will want to carefully evaluate the stability of the local utility and its rate policies before committing to H.I.D. lighting.

Some of the points brought out in this analysis may be considered as elements necessary for a successful venture. A primary consideration is that high levels of quality bloom production are absolutely required. The high annual solar radiation in the Southwest, particularly in the winter time when the crop is growing for holiday sales, is a natural resource benefit that has considerable financial rewards. By not having to invest in and operate H.I.D. lighting, the Southwest grower saves on financing and annual operating costs to an enormous degree relative to the other regions.

A second necessary element is a skilled labor force that is both willing and able to work for competitive wage rates. Annual costs for labor, expressed as a percentage of the total operating budget, range between 40 to $50 \%$. Labor costs represent the single largest expenditure for a grower. Opportunities for enhanced automation, the substitution of capital for labor, appear to be limited. Therefore the grower will have to attract labor at rates that are both sufficient for the worker and competitive for a profitable enterprise. Because the overall cost of living tends to be considerably lower in the Southwest, labor rates also tend to be lower, particularly for agriculture-based labor. It is likely that the relative cost-of-living indices will continue to be lower in the Southwest, therefore contributing to a long-tem economic advantage for the grower.

In summary, it is estimated in this report that a cut-flower rose operation may be established and operated in a Southwest location at a profitable level. Because of the lower real estate prices in the Southwest, less capital is required to start a new greenhouse business. In addition, no special incentives are necessary for the operation. Rather, the Southwest offers natural resource and cost of living advantages that make the region an economically-preferred location. U.S. growers, seeking expansion or relocation sites, should consider the opportunities afforded by a Southwest location. New growers to the industry should consider the Southwest as the primary location for their business planning. 


\section{Appendix A \\ Financial Model Description}

\section{SECTION 1. ASSUMPTIONS FOR OPERATING ANALYSIS Greenhouse Assumptions}

LAND COST: Land cost estimations are based on known prices of existing and likely possible locations. Commercial real estate brokers were contacted in the selected locations, given a brief explanation of the study, and asked to estimate a price for a ten-acte plot of land suitable for commercial greenhouse operations.

ROSE PLANTS PER ACRE: The figure given for the number of rose plants per acre is based upon averages cited by various experienced growers.

TOTAL NUMBER OF ROSE PLANTS: The total number of rose plants is determined by multiplying the number of rose plants per acre by the number of acres in production.

ROSE PLANT COSTS: Rose plant costs are approximations based on price lists distributed by plant wholesalers.

AVERAGE BLOOM SELLING PRICE: The bloom selling price is an annual weighted average selling price that will vary with the grower's location. The grower's market is usually a function of the location of his operations, and because transportation costs are assumed by the wholesaler, these costs become an important factor in determining the bloom selling price.

BLOOM PRODUCTION: The number of blooms produced by one Royalty plant per any given year is an approximation cited by a number of experienced rose growers in the selected areas and varies by location and/or the presence of H.I.D. lighting. Bloom production rates are calculated to vary by the amount of sunshine that a location receives.

EMPLOYEES PER ACRE: The number of people employed to work a one-acre area of production varies depending on the degree of automation in any particular greenhouse operation. A low level of automation is assumed for this study. 
PRODUCTION LOSSES: With any type of production there will be shrinkage or production losses due to stem quality and/or the quality of post-harvest handling. The figure cited for production losses is an estimate suggested by experienced rose growers. A dry climate is expected to have fewer losses than a humid climate because of generally lower disease-related problems.

BLOOMS SOLD PER YEAR: The total estimated number of blooms sold per year is arrived at by multiplying bloom production by the number of rose plants by the number of acres in production, then subtracting the allowance for production losses.

GREENHOUSE SIZE: It is assumed that four acres is a reasonable size for a startup commercial operation.

ACRES: A ten-acre plot is assumed. Six of the ten acres will be used for warehouse/office facilities, parking, supply storage, and will also allow for future expansion.

H.I.D. LIGHTING: The assumed cost of H.I.D. lighting is $\$ 200$ per lamp and includes installation.

H.I.D. LAMPS/ACRE: It is assumed that 785 four-hundred watt H.I.D. lamps are required per acre of greenhouse.

\section{Economic Assumptions}

STATE TAX RATE: Corporate state rates are calculated assuming a base tax rate in order to simplify calculations. Rules for the period of time tax losses may be carried forward vary by state; however, in order to simplify calculations, tax losses are carried over. and back for a one-year period. Tax credits and special incentives are not considered in this analysis.

FEDERAL TAX RATE: Federal tax calculations are based on a flat rate and remain constant across the United States. The I.R.S. allows tax losses to be carried over for up to five years and carried back for three years. However, in order to simplify calculations, tax losses are carried over and back for a one year period. Tax credits and other special deductions are not considered in this study.

F.I.C.A. (Social Security) TAX RATE: F.I.C.A. taxes are calculated based on the current flat rate and remain constant across the U.S. 
S.U.T.A. (State Unemployment) TAX RATE: Unemployment taxes are calculated based on the standard rate for new employers and will vary by state. New employers are assessed the standard rate until such time that they establish individual experience rates.

WORKERS' COMPENSATION RATE: Workers' Compensation rates were obtained by contacting the appropriate state offices. The rates apply to greenhouse workers in a newly-established greenhouse operation. Actual future rates will be determined by each individual greenhouse's experience rate after a certain time period.

VEHICLE FEE: It is assumed that greenhouse operators will use a van for local delivery and miscellaneous errands. The fee refers to the estimated cost per mile that operating a vehicle requires.

VEHICLE MIIES DRIVEN PER YEAR: The delivery vehicle will be driven a given number of miles per year.

GENERAL LNFLATION RATE: The financial model allows for the projection of costs and revenues adjusted for inflation. A zero inflation rate implies a constant dollar analysis over the given time horizon.

LABORER WAGE RATE: Labor costs include all wages paid to workers except administrative and marketing personnel. The laborer wage rate cited is computed using the American Chamber of Commerce Researchers Association "Inter-City Cost of Living Index, Third Quarter, 1988."

WORK WEEK: The work week is assumed to be six, eight-hour days. Workers are not compensated at a higher overtime rate unless they work over forty-eight hours per week.

PROPERTY TAX RATE: Real property tax rates for each location were obtained by contacting respective local and state government offices.

\section{Utility Assumptions}

ELECTRICITY ENERGY RATE: Electricity rates were determined by contacting local electric utility companies and are calculated in terms of dollars per kilowatt hour. The rates for greenhouses typically fall under the "Commercial User" category. Cost calculation a are based on flat base rates with no allowances for factors such as 
deposits, minimum monthly customer charges, taxes, or different meter sizes.

ELECTRICITY DEMAND RATE: Electricity demand rates were determined by contacting local electric utility companies and are calculated in terms of dollars per kilowatt per month. Not all electric companies assess demand charges.

H.I.D. ELECTRICITY ENERGY RATE: Electricity rates for H.I.D. lighting were determined by contacting local electric utility companies and are calculated in terms of dollars per kilowatt hour. Some electric companies offer "Off-Peak" reduced rates. It was assumed that H.I.D. lighting would not be used unless an off-peak rate or relatively low electricity rates were available. Cost calculations are based on flat base rates with no allowances for factors such as deposits, minimum monthly customer charges, taxes, or different meter sizes.

H.I.D. ELECTRICITY DEMLAND RATE: Electricity demand rates for H.I.D. lighting were determined by contacting local electric utility companies and are calculated in terms of dollars per kilowatt per month.

NATURAL GAS RATE: Natural gas rates were determined by contacting local private and municipal gas companies and are calculated in terms of dollars per million BTU.

WATER RATE: Water rates were determined by contacting local private and municipal water companies and are calculated in terms of dollars per thousand gallons.

HEATING FUEL INFLATION RATE: The financial model allows for the projection of costs and revenues adjusted for inflation. A zero inflation rate implies a constant dollar analysis over the given time horizon.

ELECTRICITY INFLATION RATE: The financial model allows for the projection of costs and revenues adjusted for inflation. A zero inflation rate implies a constant dollar analysis over the given time horizon.

HEATING LOAD: The heating load is calculated with a computer-assisted energy simulation model for each location, and the load is reported in terms of millions of BTU for a four-acre 
greenhouse complex. A printout of the computer inputs is included in Appendix $C$.

ELECTRICITY LOAD: The electricity load is computed by summing the total annual hours of sunlight for each location, which was obtained from the "Facility Design and Planning Engineering Weather Data," published by the Departments of the Air Force, the Army, and the Navy. Both kilowatt hours per acre per year and kilowatts per acre are calculated.

H.I.D. ELECTRICITY LOAD: The H.I.D. electricity energy load is based on the total number of H.I.D. lights operating sixteen hours per day, seven months per year. Both kilowatt hours per acre per year and kilowatts per acre are calculated.

WATER CONSUMPTION: An estimate of the number of gallons of water per acre of covered area per year per location is assumed, based on data obtained from "Greenhouse Roses," published by Roses Inc., and from individual greenhouses. It is assumed that greenhouses in locations that do not utilize evaporative cooling use approximately one-half the amount of water utilized by greenhouses using evaporative cooling.

BOILER EFFICIENCY: Because a natural gas burner/boiler has combustion inefficiencies, the boiler is assumed to be $75 \%$ efficient.

$\mathrm{CO}_{2}$ : The approximate square footage cost to generate carbon dioxide was obtained from the Ball Red Book. $\mathrm{CO}_{2}$ will only be used from October to April.

\section{Amortization Assumptions}

PRINCIPAL: A debt-to-assets ratio of approximately $70 \%$ is typical for this industry segment (Bedding Plants, Inc., 1988 Greenhouse Operating Performance Report). Total capital costs were multiplied by $70 \%$ to obtain the principal.

INTEREST RATE: A given interest rate is assumed. The interest rate is $8.5 \%$, which may be somewhat low for a current market rate. However, the authors believe $8.5 \%$ reflects a high interest rate since

no inflationary effects are incorporated into the model. Thus, the $8.5 \%$ rate reflects a real or true rate and, in this case, is a 
conservative figure. This rate is used for the calculation of the loan payment and for the net present value calculation.

YEARS: The loan is amortized for the given time period.

ANNUAL LOAN PAYMENT: The annual loan payment is a sum of the principal and interest calculated for the specific year. Annual interest is calculated by multiplying the total loan balance at the beginning of the year by the interest rate. The principal is calculated by subtracting the interest from the annual payment.

DEPRECIATION: Total capital building and equipment costs are depreciated for a given time period, based upon the straight line depreciation method.

\section{Cash Flow Assumptions}

DEBT: It is assumed that $70 \%$ of total capital costs will be debt financed.

PERCENTAGE OF CASH AVAILABLE FOR OPERATIONS ABOVE CAPITAL COSTS: It is assumed that $30 \%$ of total capital costs are owner financed. An additional contingency allowance of $15 \%$ of total capital costs is included for operations.

CASH AVAIIABLE FOR OPERATIONS: Total cash available for operations is the sum of total capital costs and contingency funds.

BEGINNING CASH: The beginning cash amount is the sum of the owner's contribution and the contingency funds.

\section{SECTION 2. GREENHOUSE CAPITAL COSTS}

Capital cost estimates for the greenhouse were obtained either from conversations with local growers and wholesalers, or from published reports.

\section{Capital Outlay}

LAND: The land cost estimation is for a ten acre plot amortized for a twenty-year period along with other capital costs.

PLANTS: The initial purchase of rose plants are amortized for a seven-year period. The rose plants must be replaced every seven years. The replacement of rose plants takes place at the end of the 
seventh year, and the cost of the new plants is also amortized for seven years.

Greenhouse

STRUCTURE: The total covered area is 174,000 square feet. The design will be quonset-style bays connected at the gutters.

COVER: The roof cover is double poly that will be replaced every two years.

SOIL PREPARATION: It is assumed that the grower will have to manage the local soil with a variety of medium conditioners. The plants will be grown directly in the local soil.

COOLING SYSTEM: A pad-and-fan evaporative cooling system will be installed in most locations, however a basic fan-cooling system with side vents is used where appropriate.

HEATING SYSTEM: The use of a natural gas-fired boiler with hydronic distribution is assumed.

THERMAL CURTAN: Use of thermal sheets for either heat retention or light reduction will depend on the location of the greenhouse. These differences are included in the model.

H.I.D. LIGHTING: Natural lighting conditions in some areas of the country make the need for H.I.D. lighting necessary.

FREIGHT: A freight cost for incoming supplies is assumed.

IRRIGATION SYSTEM: The use of automatically-operated perimeter watering systems is assumed.

ENVIRONMENTAL CONTROLS: Environmental computer controls are used for monitoring and controlling temperature, ventilation, and humidity.

FERTILIZER INJECTOR: The use of centralized fertilizer injectors is assumed.

SORTING MACHINE: The use of an automatic sorting machine is assumed.

$\mathrm{CO}_{2}$ GENERATOR: The use of a $\mathrm{CO}_{2}$ generator is assumed. $\mathrm{CO}_{2}$ will only be used from October to April.

CONCRETE WALKS: The cost of laying concrete walks is included. 


\section{Other Capital Equipment}

METAL BUILDING: Estimated costs for a metal building to include office space and a headhouse area is is included.

OFFICE EQUIPMENT: It is assumed that office equipment includes a copier, computer, software, timeclock, and other miscellaneous supplies.

PLANT COOLING STORAGE UNIT: The use of a storage unit to refrigerate or cool flowers is assumed.

DELIVERY VEHICLE: The use of a van for local pick-up and delivery purposes is assumed.

MISCELLANEOUS: An additional allowance for miscellaneous items not included elsewhere is assumed.

\section{SECTION 3. OPERATING BUDGET CASH FLOW}

The third section shows a projected cash flow on a yearly basis for the first ten years of greenhouse operation. It is anticipated that it will take approximately five months to construct the greenhouse, another month to plant the roses, and an additional six to seven months before the rose plants are expected to produce saleable blooms.

\section{Sales}

SALES VOLUME: The volume of roses sold is calculated by subtracting the production losses from the blooms sold per year (see Assumptions).

SALES PRICE: The average bloom selling price is obtained from Assumptions.

SALES REVENUE: Sales revenue is calculated by multiplying the sales volume by the selling price. No sales occur in the first year, and no revenue is expected until year two.

\section{Outlay for Production}

Operating costs are typically separated into fixed and variable categories. However, annual rose production is basically constant. That is, the same number of rose plants yield approximately the same number of roses every year, and the operating requirements 
for those rose plants remain constant. Therefore, this study refers to what are normally variable expenses as production expenses. Fixed operating expenses continue to be referred to as fixed expenses.

PRODUCTION EXPENSES: Production expenses for both regular and H.I.D. electricity (where applicable), heat, water, $\mathrm{CO}_{2}$, chemicals, and fertilizer are based on the assumed rates of usage. Estimates for year one are for six months of production; estimates for the remaining years are based on twelve full months of production.

FIXED OPERATING EXPENSES: Administrative salaries including the owner/manager, grower, sales, legal/accounting, and maintenance positions are assumed to be fixed annual salaries. Because planting and production will not begin until after the sixth month, year one salary estimates are lower than those of later years. Allowances for annual salary increases are not included in this study.

Hourly wages are assumed for laborers and are estimated to begin in the sixth month. Hourly wages are also assumed for delivery personnel. These costs are not incurred until year two.

F.I.C.A. and S.U.T.A. costs are incurred in direct proportion to both fixed and hourly annual wages paid. Workers' Compensation costs are based on annual wages paid to laborers and to delivery and maintenance personnel.

Cost estimates for trash disposal, crop insurance, property insurance, overhead, repairs and maintenance, and vehicle operation and maintenance were obtained either from conversations with local growers or from published reports. These costs are pro-rated for year one, and it is assumed that they will remain constant for the following nine years.

OTHER FIXED EXPENSES: Other fixed expenses include the breakdown of principal and interest in the total annual loan payment.

TAXES: Federal and state income taxes are calculated based on the tax rates (see Note 1 ).

CASH FLOWS: Year-end cash flows are determined by subtracting net cash inflow after tax balances from beginning cash flow balances. The year-one beginning cash flow amount is obtained from the "Assumptions" section. 
SECTION 3a. NOTE 1

NET CASH INFLOW FOR TAX CALCULATION: The net cash inflow for tax calculations is determined by subtracting the tax deductible interest and depreciation allowances from the net cash inflow from operations. Depreciation is assumed to be straight line for a seven year period. The simplified allowance for tax loss carryover and carryback is for one year only.

BALANCE: The balance determines the tax loss carryover or carryback.

\section{SECTION 4. FINANCIAL CALCULATIONS Profitability}

AVERAGE BLOOM SELLING PRICE: The average bloom selling price is given in the "Assumptions" section.

NET PRESENT VALUE (NPV): The NPV is calculated based on annual after tax cash flows for a twenty year period and discounted at the interest rate given.

INTERNAL RATE OF RETURN (IRR): The IRR is the rate that equates the present value of expected future after tax cash flows to the initial cost of the project. The calculation is for a projected twenty-year period.

RETURN ON INVESTMENT (ROD): The ROI is calculated for year two by dividing the year-two net cash inflow after taxes by the total capital costs.

PROFIT MARGIN: Profit margin for year two is calculated by dividing net income after taxes by year-two annual sales.

\section{Breakeven Analysis}

ANNUAL SALES: The amount given for annual sales revenue is for year two.

ANNUAL PRODUCTION EXPENSES: The amount given for annual production expenses is for year two.

ANNUAL FIXED EXPENSES: The amount given for annual fixed expenses is for year two and is the sum of total fixed operating expenses and total other fixed expenses. 
NET INCOME: Net income is calculated as the annual sales less the sum of annual production expenses and annual fixed expenses for year two.

SALES REQUIRED FOR BREAKEVEN: Breakeven sales doilars represent the volume of sales at which total costs equal total revenues. The calculation is based on year two costs and revenues.

BREAKEVEN AVERAGE BLOOM SELLING PRICE: The breakeven average selling price is determined by dividing the breakeven sales dollars (the sum of annual production expenses and annual fixed expenses) by the annual tocal sales volume.

\section{Effects of Changes in Average Bloom Selling Price}

The effects of changes in average bloom selling price on firm profitability is indicated. Five-cent increases in the bloom selling price are used to illustrate the effect on profit margins.

Greenhouse

INSTALLED COST: The installed cost is the sum of the costs per square foot for the greenhouse and greenhouse installation. Other capital equipment costs are not included in this calculation.

PRODUCTIVE AREA: The productive area is calculated by dividing the number of rose plants per acre by the number of square feet per acre.

Utilities

HEATING COSTS: Heating costs per square foot are calculated by dividing the annual heating expenses by the total of 174,000 square feet.

ELECTRICITY COSTS: Electricity costs per square foot are calculated by dividing the annual electricity expenses by the total of 174,000 square feet.

Reverue

DOLLARS PER SQUARE FOOT (TOTAL SALES REVENUE): Revenue dollars per square foor ( $\$ / \mathrm{sq}$. ft.) is determined by dividing total sales by 174,000 square feet. 
DOLLARS PER SQUARE FOOT (NET CASH AFTER TAXES):

Revenue dollars per square foot ( $\$$ /sq. ft.) is also calculated in terms of net cash inflow after taxes and is determined by dividing net cash inflow after taxes by 174,000 square feet.

\section{Operating Budget}

The operating budget category includes various key operating costs expressed in terms of percentage of total expenses and provides a convenient method to compare costs at different locations. It is based on year two costs and revenue. 
Greenhouse Assumptions

Land cost (S/acre)

$\$ 12,500$

Rose plants per acre

31,500

Total \# of rose plants

Rose plant costs ( $\$$ / plant)

126,000

$\$ 3.00$

Average bloom selling price

$\$ 0.32$

Bloom production (blooms/plant/year) 30

Production losses

Net blooms (plant/year)

Blooms sold per year

$3,591,000$

Emplovees per acre

Greenhouse size (acies)

Acres (total)

Square feet/acre

Warehouse/Office (sq. ft.)

Economic Assumptions

State tax rate

Federal tax rate

F.I.C.A. rate

$1+\%$

S.U.T.A. rate

$2.7 \%$

Workers' Compensation $/ \$ 100$

$\$ 4.50$

Vehicle fee ( $\mathrm{S} / \mathrm{mile}$ )

$\$ 0.30$

Vehicle miles driven per year

20,000

General inflation rate

$0 \%$

Laborer wage rate

$\$ 4.50$

Work week (hours)

Property tax rate $(\$ / 1,000,1 / 3$ valuation)

$\$ 20.95$

Utility Assumptions

Electricity energy rate $(\$ / \mathrm{kWh})$

$\$ 0.075$

Electricity demand rate $(\$ / \mathrm{kW} / \mathrm{Mo})$

$\$ 14.00$

Natural gas rate ( $\$ / \mathrm{MMBTU}$ )

$\$ 3.25$

Water rate $(\$ / 1,000$ gal)

Heating fuel inflation rate

$\$ 1.00$

Electricity inflation rate

Heating load (MMBTU/4 acres)

$0 \%$

$0 \%$

16,217

Electricity load ( $\mathrm{kWh} /$ year/acre)

120,000

Electricity load (kW/acre)

Water consumption (gal/acre/year)

$4,888,500$

Boiler efficiency

$75 \%$

$\mathrm{CO}_{2}$ (\$/sq. ft. to generate)

$\$ 0.20$ 
Assumptions Cont.

Amortization Assumptions-Initial Outlay

Principal

Interest rate

$51,307,730$

Years

$8.5 \%$

Annual loan payment ( $P \& I)$

20

Depreciation (\# years, straight line basis)

$\$ 159,323$

Cash Flow Assumptions

Debt (\% of total capital costs)

$\%$ of cash avail. for op. above capital costs

Cash available for operations

Beginning cash

$70 \%$

$15 \%$

$\$ 2,476,985$

$\$ 969,255$ 
TABLE B-26. GREENHOLSE CAPITAL COSTS FOR THE LAS CRLCES AREA

Capital Outlay

$\$ 125,000$

Sisq ft

Land

$\$ 378,000$

Greenhouse

Structure

$\$ 391,500$

$\$ 2.25$

Cover (replace every two years)

$\$ 26,100$

$\$ 0.15$

Soil Preparation

$\$ 25,000$

$\$ 0.14$

Pad \& Fan Cooling

$\$ 139,200$

Heating System

Freight

$\$ 278,400$

$\$ 17,400$

$\$ 0.80$

$\$ 1.60$

$\$ 15,000$

$\$ 0.10$

Concrete Walks

$\$ 0.09$

Greenhouse Installation

Structure

$\$ 174,000$

$\$ 1.00$

Pad \& Fan

$\$ 26,100$

$\$ 0.15$

Heating

Electrical Wiring

$\$ 17,400$

S0.10

$\$ 69,600$

$\$ 0.40$

Plumbing

$\$ 43,500$

\$0.25

Irrigation System

Environmental Controls

Fertilizer Injector

$\$ 121,800$

50.70

$\$ 60,900$

\$0.35

$\$ 8,700$

$\$ 0.05$

$\$ 25,000$

$\$ 26,100$

$\$ 0.15$

Total Greenhouse only

$\$ 1,465,700$

$\$ 8.28$

Other Capital Equipment

Metal Building (includes office)

$\$ 65,800$

Office Equipment

$\$ 30,000$

$\$ 29,400$

Concrete Pad (Metal bidg. only)

$\$ 30,000$

$\$ 5,000$

Cool Storage Installation

$\$ 15,000$

Delivery Vehicle (van)

$\$ 10,000$

Total other

$\$ 185,200$

TOTAL

$\$ 2,153,900$ 


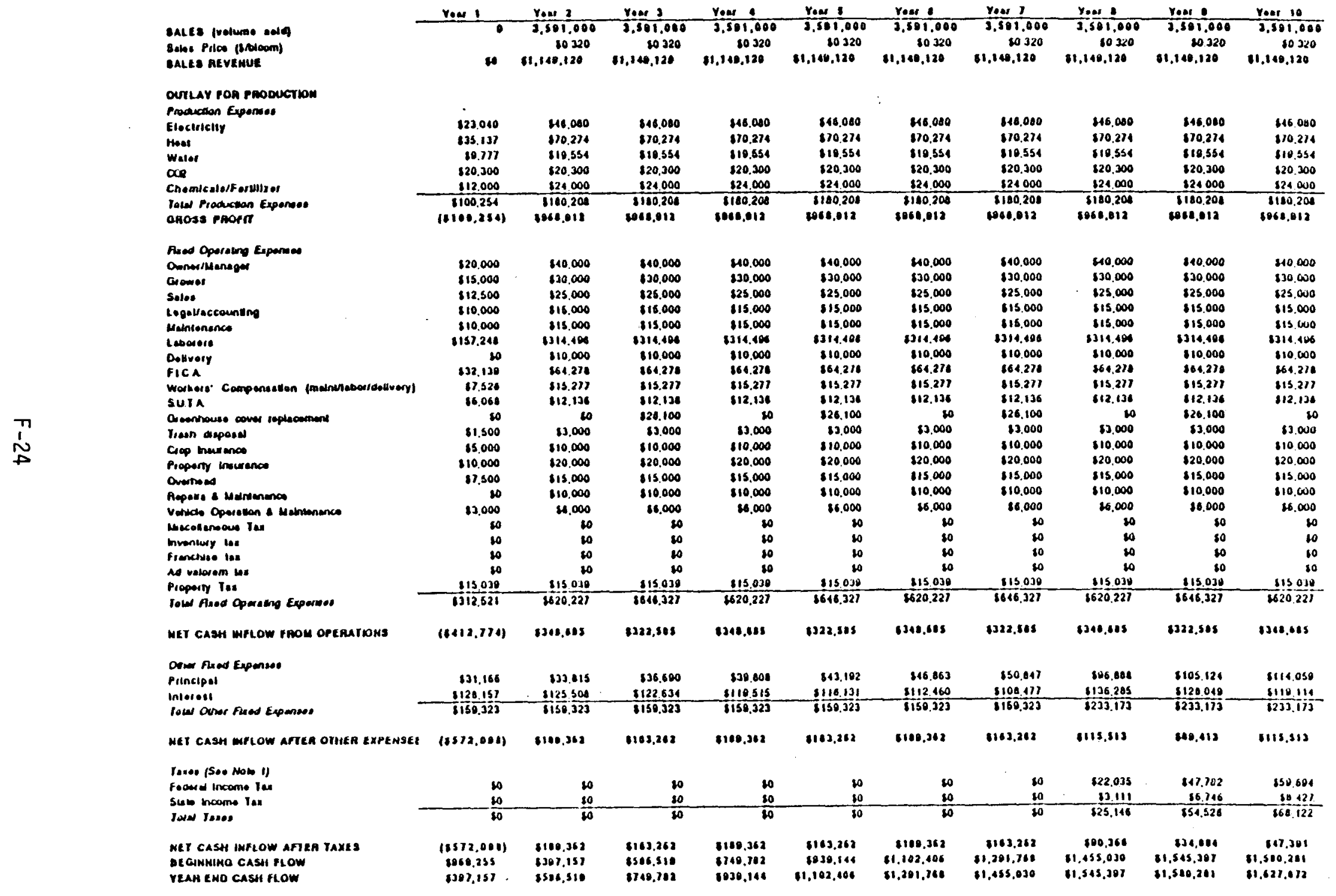




\begin{tabular}{|c|c|c|c|c|c|c|c|c|c|c|}
\hline & Yoes ! & roat 2 & Yoar 3 & Yoat 4 & Yous & roar 6 & roar 1 & roes & Yeste & $Y . . .10$ \\
\hline MET CASHI WHLOW FROW OPERATIONG & $(5+12.174)$ & BJe4,6es & s32.525 & 8341,645 & \$322,525 & 8348,6015 & 8322,505 & $\$ 368,605$ & \$222.50s & 8341,605 \\
\hline 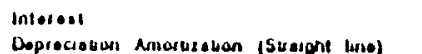 & $\begin{array}{l}8128,15\rangle \\
1301,100\end{array}$ & $\begin{array}{l}8125.500 \\
8307,700\end{array}$ & $\begin{array}{l}8122,634 \\
8307700\end{array}$ & $\begin{array}{l}\$ 110.515 \\
8307,100\end{array}$ & $\$ 116.131$ & 8112.460 & $\$ 108.47$ & 8136.205 & 8120.048 & 1110.114 \\
\hline rotos & 8135.057 & 8133.200 & 3130,334 & 8227.215 & 3123,831 & $\frac{1307.700}{1120.160}$ & $\frac{8307.700}{8116.177}$ & $\frac{854000}{8100.205}$ & $\frac{154.000}{1182.049}$ & $-\frac{844000}{5133.111}$ \\
\hline met CASHI IMfLOW FOA IAX Cal CULATHO & $(10040,631)$ & $(1004.522)$ & $(6107.741)$ & $(370.530)$ & $(8101,246)$ & $(671.475)$ & $(602.501)$ & 5150,401 & 1140.536 & 8175,572 \\
\hline 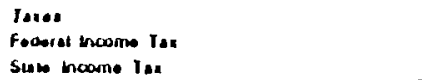 & 10 & so & 10 & $\begin{array}{l}30 \\
30\end{array}$ & so & 80 & 80 & $\begin{array}{l}\$ 22,035 \\
\$ 3,111\end{array}$ & $\begin{array}{l}117.782 \\
86,716\end{array}$ & $\begin{aligned} 850.694 \\
10421\end{aligned}$ \\
\hline loted lases & 10 & 80 & 10 & 20 & 50 & 50 & 50 & 125.146 & 350.528 & $-\frac{16421}{86.122}$ \\
\hline 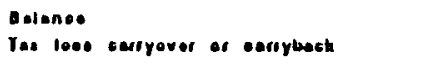 & $\begin{array}{l}(30,11,631) \\
(60+16,6) 1)\end{array}$ & $\begin{array}{l}(124,822) \\
(104,522)\end{array}$ & $\begin{array}{l}(3107.740) \\
(1107.740)\end{array}$ & $\begin{array}{l}(679.530) \\
(679.530)\end{array}$ & $\begin{array}{l}(8101,246) \\
(1101,246)\end{array}$ & $\begin{array}{l}(511,475) \\
(611,475)\end{array}$ & $\begin{array}{l}(103.591) \\
(1803.501)\end{array}$ & $\begin{array}{l}3133,255 \\
\$ 60,011\end{array}$ & $\begin{array}{l}501,008 \\
3205,246\end{array}$ & $\begin{array}{l}3107.450 \\
1300.011\end{array}$ \\
\hline
\end{tabular}


TABLE B-2S. FINANCIAL CALCULATIONS FOR THE LAS CRLCES AREA

\begin{tabular}{lcccccc}
\hline \hline & $\begin{array}{c}\text { Annual } \\
\text { Production } \\
\text { Expenses } \\
\text { Price }\end{array}$ & $\begin{array}{c}\text { Annual } \\
\text { Fixed } \\
\text { Expenses } \\
(S)\end{array}$ & $\begin{array}{c}\text { Total } \\
\text { Expenses } \\
(S)\end{array}$ & $\begin{array}{c}\text { S) } \\
(S)\end{array}$ & $\begin{array}{c}\text { Net Lncome } \\
(S)\end{array}$ & $\begin{array}{c}\text { Profit } \\
\text { Margin } \\
(\%)\end{array}$ \\
\hline 0.25 & 897,750 & 180,208 & 779,550 & 959,758 & $-62,008$ & -7 \\
0.30 & $1,077,300$ & 180,208 & 779,550 & 959,758 & 117,542 & 11 \\
0.35 & $1,256,850$ & 180,208 & 779,550 & 959,758 & 297,092 & 24 \\
0.40 & $1,436,400$ & 180,208 & 779,550 & 959,758 & 496,642 & 33 \\
0.45 & $1,615,950$ & 180,208 & 779,550 & 959,758 & 656,192 & 41 \\
\hline
\end{tabular}

Figure B-7

Operating Budget Distribution, Las Cruces

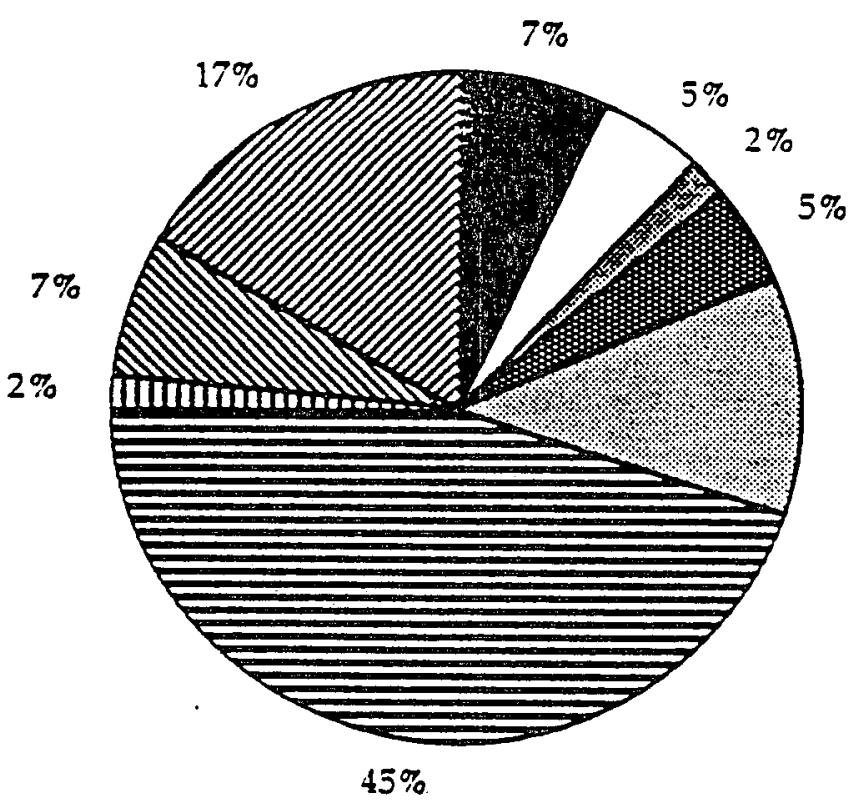

Heating

Electricity

Water

Materials

Salaries-ígmt

Salaries -Hourly

II Property Tax

Overhead

Q Loan Payment ( $P$ \& I) 